\title{
Trap-Neuter-Return: A Study of the Practice in Switzerland
}

\author{
Elizabeth Umlas \\ $\mathrm{PhD}$, Yale University (Political Science) \\ MA, Universidad Autónoma de Barcelona (Animal Law \& Society) \\ Independent researcher, Switzerland
}

Received: March 2021

Accepted: April 2021

Recommended citation. UMLAS, E., Trap-Neuter-Return: A Study of the Practice in Switzerland, dA. Derecho Animal (Forum of Animal Law Studies) 12/2 (2021). - DOI https://doi.org/10.5565/rev/da.563

\begin{abstract}
Trap-Neuter-Return (TNR) is well-established in many countries and increasingly considered to be the most effective and humane way to manage feral and stray cat populations. Nonetheless, it confronts major challenges everywhere it is practiced. Although Switzerland has an impressive TNR system carried out mainly by private, non-profit organizations and individual citizens, the management of feline overpopulation could be strengthened by improvements on a number of fronts, including legal and governance changes, education and modifications in mentality, and operational adjustments such as data management and analysis. TNR faces a number of common challenges worldwide, and given that it is still relatively young, lessons from one country can be valuable for another. Because little has been written about TNR in Switzerland, this article seeks to fill this gap by providing a preliminary analysis of the case through the prism of existing analytical work done on TNR in other countries.
\end{abstract}

Keywords: trap-neuter-return (TNR); feline overpopulation; community cats; Switzerland.

Resumen - Captura-Esterilización-Suelta: estudio sobre su aplicación en Suiza

El método Captura-Esterilización-Suelta (CES) está implementado en muchos países y está cada vez más considerado como la forma más eficaz y ética de gestionar las colonias de gatos callejeros y ferales. Sin embargo, todavía se enfrenta a grandes desafíos en aquellos lugares donde se practica. Aunque en Suiza se lleva a cabo un impresionante método CES por parte de la ciudadanía y de organizaciones privadas sin ánimo de lucro, dicha gestión de la sobrepoblación felina podría mejorarse con diversas modificaciones legales y políticas, educacionales y de concienciación, además de ajustes como la gestión y el análisis de los datos existentes. El método CES enfrenta una serie de desafíos comunes en todo el mundo y, dado que aún es relativamente joven, las acciones de ciertos países pueden ser ejemplo para otros. Debido a las escasas publicaciones sobre el método CES en Suiza, este artículo pretende proporcionar un análisis preliminar de la situación a través del análisis ya existente sobre el mismo en otros países.

Palabras clave: Captura-Esterilización-Suelta (CES); sobrepoblación felina; gatos comunitarios; Suiza. 


\section{Section 1. Introduction}

Feline overpopulation - the excessive or uncontrolled breeding of primarily unowned, stray or feral cats - is a problem worldwide. Not only does it cause animal suffering; it also brings conflict between animal and human populations. One reaction to this problem, still practiced in many areas, ${ }^{1}$ is to try to control overpopulation by culling feral or stray cats through methods such as trapping and killing them, poisoning or shooting them, or introducing feline diseases into feral populations. These methods have rightly been criticized in both animal welfare and efficacy terms: they are increasingly rejected as inhumane, and they have not been proven to stop overpopulation. What is more, they have been accused of being a "bandaid" solution: an attempt to address the symptom without confronting key contributors to the problem, such as pet owners' abandonment of their cats or people's tendency to allow their intact cats to roam and breed freely with unowned cats.

Beginning in the 1980s and increasing in the ensuing three decades, the method of "trap-neuter-return" (TNR) has gained stature as a humane way to tackle feline overpopulation. In TNR, unowned cats living in urban or rural areas are trapped, neutered or spayed and sometimes vaccinated by veterinarians, their ear tips surgically removed for identification, and the cats returned to where they were found, with the goal being an eventual reduction in the cats' numbers as they no longer reproduce (feral cats are often unadoptable, hence the logic of returning them to live out their lives where they were found; adoption of "socializable" stray cats, on the other hand, is an important part of TNR). Ongoing monitoring of the released cats is carried out, often by volunteers, to ensure new arrivals are also neutered to prevent more breeding. As will be discussed in section 2, the method is growing in popularity with the public; articles in scientific journals present evidence of successful TNR programs; and municipalities in multiple countries are beginning to support TNR, including through formal accords and the creation of local ordinances.

But while TNR is well-established in many countries, it still faces major challenges everywhere it is practiced. Switzerland is one of a handful of countries with active and well-run TNR programs. Although much has been written about TNR in the United States, including in scientific journals, and articles, case studies and reports have been published on several other countries' TNR programs (including Spain, the United Kingdom, Italy, Portugal, Australia, and Israel), very little has been written about Switzerland, outside of the public materials of TNR practitioners and various press articles. Yet there is much to learn from Switzerland's experience.

This article seeks to contribute to the literature on TNR by providing a preliminary analysis of the Swiss case - both innovative aspects of its TNR and major challenges these programs continue to face - through the prism of existing analytical work done on TNR in other countries. The working hypothesis is that although Switzerland has an impressive TNR system carried out mainly by private, non-profit organizations and individual citizens, the success of this method - and thus better management of the feral and stray cat population in Switzerland - will depend on changes on a number of fronts, including legal and governance changes, education and modifications in mentality, and operational adjustments such as data management and analysis. In fact, these areas align to a significant degree with the continued challenges and lessons learned so far from other countries' TNR programs. These other experiences, while not a blueprint for Switzerland, could therefore provide inspiration and perhaps guidance for Swiss TNR. Every country is different and therefore TNR approaches will, and should, differ from one place to another. Nonetheless, TNR has certain shared features and confronts a number of common challenges worldwide, and because it is still a relatively young practice (dating back only to the 1980s or 1990s, in most cases), lessons from one country can be valuable for another.

The article starts from a perspective that rejects lethal methods of community cat management in favor of methods that take account of the welfare of individual animals. It accepts that TNR is the only humane and effective way to address feline overpopulation. One goal of the article is to bring an understudied case to light; a related goal is to use this case to further the learning around TNR and how it can be strengthened both as a method of animal population control that can reduce animal suffering and as a way to address human-animal conflict.

The structure of the remaining sections is as follows: section 2 provides a general discussion of what TNR entails, citing the growing literature on successful cases in multiple countries as well as increasing support for the practice in different quarters (the general public, professional associations, municipalities). It also briefly presents key criticisms of TNR and some of the responses to these by proponents and experts, and

\footnotetext{
${ }^{1}$ Alley Cat Allies. Why Trap-Neuter-Return Feral Cats? The Case for TNR. https://www.alleycat.org/resources/why-trap-neuterreturn-feral-cats-the-case-for-tnr/ [Last consulted 4 May 2019]
} 
touches on unanswered but valid questions surrounding TNR. Section 3 introduces the Swiss case, first setting out why this case was chosen and providing a brief overview of the situation of owned, stray and feral cats in the country. It proceeds to a discussion of Swiss animal welfare law and relevant laws relating to feral and stray cats. Section 4 lays out the landscape of TNR in Switzerland, and explores its strengths and innovative features. Section 5 contains a discussion of the changes needed to improve TNR and the management of community cats in Switzerland, at the same time calling on lessons that have begun to emerge from TNR programs in various countries that are addressing similar challenges. The concluding section enumerates limitations of the study and suggests areas for further research.

Regarding methodology, the research for the article included an extensive review of secondary materials, supplemented by primary research in the form of interviews of several key informants. ${ }^{2}$ The informants interviewed in Switzerland represented a range of organizations working in the area of animal welfare, including the headquarters of the Swiss Society for the Protection of Animals, some of its sections or partners, other NGOs carrying out TNR, an animal welfare foundation, a leading Swiss animal law foundation, a women's farmer organization and a veterinarian. An attempt was made to consult experts who have worked on TNR in different parts of the country, and representing both French and German-speaking cantons, as there are political and cultural differences across these entities (including approaches to animal welfare). Due to limitations of time and research as well as linguistic constraints, only a selection of Swiss cantons are represented in the interviews. That said, some of the organizations interviewed work in multiple cantons or even at the national level. An attempt was also made to consult organizations working with community cats in both urban and rural areas.

A first set of interviews of organizations and individuals led to further recommended contacts, who were then interviewed. In a small number of cases, interviewees responded in writing to a limited set of questions, but in most instances, semi-structured interviews were carried out in person or by telephone. The data sought (and analyzed) were mostly qualitative in nature, not quantitative. The Swiss key informant interviews were supplemented by an interview of the staff attorney of Alley Cat Alleys, a US NGO with one of the oldest and best-known TNR programs in that country.

\section{Definitions}

Because of the multiplicity of terms related to TNR, it is worth setting out some definitions before proceeding to the substance. TNR operations generally target unowned domestic cats, but that group itself encompasses cats with a range of behaviors, lifestyles and relationships with human beings. The following definitions, drawn from several sources, are meant to clarify terms that will be used in subsequent sections of the article:

- Cat colony: "Stable, and generally amicable, group of cats living together in the same environment" or "a feeding area and shelter frequented by an apparently stable population of cats" 4

- Community cat: "[A]ny free-roaming cat or kitten, whether abandoned, stray, lost or feral, that may be cared for by one or more known or unknown residents... and that may live on its own or in a colony of other such felines" 5

- Feral cats: "unowned and unsocialized cats"6; feral cats "are either born in the wild and lack socialization or are abandoned to the wild and become untrusting of humans"7

\footnotetext{
${ }^{2}$ In total, 14 specialists were consulted, 12 of them in Switzerland.

${ }^{3}$ ISFM. ISFM Guidelines on Population Management and Welfare of Unowned Domestic Cats (felis catus) in Journal of Feline Medicine and Surgery 15 (2013), 811-817

${ }^{4}$ Levy, J.K., Gale, D.W., Gale, L.A. Evaluation of a Long-term Trap-Neuter-Return and Adoption Program on a Free-roaming Cat Population, in Journal of the American Veterinary Medical Association 222(1) (1 January 2003)

${ }^{5}$ Schaffner, J.E. Community Cats: Changing the Legal Paradigm for the Management of So-Called "Pests". Syracuse Law Review 67:71 (2017), n. 189, citing LAKE COUNTY, FLA., Ordinance \$4-3 (Bd. Of Cty. Comm'rs of Lake Cty., Fla., Proposed Official Draft No. 4-22-15, 2015.) Cf. Spehar and Wolf, who write that "unowned, free-roaming cats" are "often referred to as 'stray' or 'feral', terms typically used interchangeably in the U.S. and Canada", though they and many others writing about TNR use the term "community cats." Spehar, D.D., Wolf, P.J. Integrated Return-to-Field and Targeted Trap-Neuter-Vaccinate-Return Programs Result in Reductions of Feline Intake and Euthanasia at Six Municipal Animal Shelters, in Frontiers in Veterinary Science 6:77 (2019), 2

${ }^{6}$ Slater, M.R., Shain, S. Feral Cats: An Overview in D.J. Salem and A.N. Rowan (Eds.), The State of the Animals III (Washington, D.C., Humane Society Press, 2005), 43. Cat behavior scientist John Bradshaw writes, "The general rule is, once a feral, always a feral", though he notes that researchers have observed cases of severely ill or injured feral cats becoming attached to humans who nursed them back to recovery. Bradshaw, J. Cat Sense: The Feline Enigma Revealed (Penguin Books, 2013), 106

${ }^{7}$ Levy, J.K., Crawford, P.C. Humane Strategies for Controlling Feral Cat Populations, in Journal of the American Veterinary Medical Association 225: 9 (2004), 1354-1360
} 
- Stray cat: "A cat that was formerly owned as a household pet (spending part of its life within a home) but is now free-living outside of the home. Such cats often accept direct human contact and may be partially or fully dependent on a human care-giver" 8

- Street cats: "Street cats are similar to 'community cats' except that they are not generally specifically cared for by an individual human or group of humans and may thus be less dependent on humans and less accepting of human contact"9

An additional category specific to Switzerland and that will be referred to throughout is "farm cat" ("chat de ferme" or "chat à la ferme"), which is a cat "living on or around a farm, theoretically where the owner and responsible person is the farmer." 10 As will be seen, these cats are an important target of Swiss TNR operations. One Swiss veterinarian points out that "these different definitions show that there is not always a sharp difference between these terms; a feral cat can also be an abandoned farm cat that wanders!"11 Or, as Levy and Crawford put it, "the lines between loosely owned outdoor cats, tame strays, and feral cats are often blurred." 12

In Switzerland, the term "TNR" (or the equivalent in the local languages) does not seem to be used commonly. Instead, practitioners generally use the term "castration campaigns" ("campagnes de castration") or "sterilization campaigns" ("campagnes de sterilisation"). For ease of reference, however, and because castration campaigns in Switzerland include trapping, neutering and returning of feral and unowned cats, the article will use "TNR" and "castration campaigns" interchangeably when discussing the Swiss case. In Switzerland the term "castration" is commonly used to refer to both spaying and neutering.

Due to language limitations, much of the research on the Swiss materials was done in French, with occasional reference to German-language materials, and the interviews were carried out mostly in French, and in some cases, in English. As the above definitions of types of domestic cats indicate, there are important differences among these categories. Nevertheless, many of the Swiss animal welfare NGOs' materials in French use the terms "chat haret" (feral cat), "chat vagabond" (stray or ownerless cat) and "chat errant" (stray cat) interchangeably when discussing TNR. Because this posed some difficulties in defining which type of cat was being discussed, the article will generally refer to "feral or stray cats" or "community cats" (a term that does not seem to be commonly used in Swiss TNR circles), except where it is possible to identify a more specific group, such as farm cats or urban cat colonies. The article thus takes a leaf from Schaffner, who urges use of the term "community cats" because it "both allows for the inclusion of all free-roaming cats, independent of their socialization, and characterizes them as individuals who share our streets and communities." 13

Where relevant, the article makes an effort to translate into English the specific terms that a group uses in its print materials, with the original language provided in the footnote for reference. It is also worth noting that in Switzerland one sometimes hears the term "chat sauvage" to refer to feral cats, though this is technically incorrect because "chat sauvage" refers to the wild cat, a protected species in Switzerland. ${ }^{14}$

A few other terms warrant definitions at the outset: "hotspots" (sometimes referred to in French as "points chauds") are "uncontrolled colonies of cats," ${ }^{15}$ wherever they might occur (farms, urban centers, and so forth). "Targeted TNR" refers to the careful definition of a location to carry out TNR for maximum effect; specifically, (when it includes vaccination) it is defined as "a systematic approach whereby efforts to trap,

\footnotetext{
${ }^{8}$ ISFM. ISFM Guidelines..., cit., 816

${ }^{9} \mathrm{Ibid}$. For a detailed table classifying cats (and dogs) in relation to their level of dependence on humans, see Alliance for Contraception in Cats and Dogs. Contraception and Fertility Control in Dogs and Cats (February 2013), 114, citing TASKER, L., Stray Animal Control Practices (Europe). World Society for the Protection of Animals and RSPCA International (2008).

${ }^{10}$ Written communication from Dr. Rose-Marie Bonvin, Veterinarian, Canton of Valais, 25 April 2019 [translated from the French: "Chat de ferme: chat vivant dans ou autour d'une ferme, théoriquement dont le détenteur et responsable est le fermier ou la fermière."]

${ }^{11}$ Ibid. [translated from the French: "Ces différentes définitions montrent qu'il n'y a pas toujours une différence tranchée entre ces termes: un chat haret peut aussi être un chat de ferme abandonné qui erre!']

${ }^{12}$ Levy, J.K., Crawford, P.C. Humane Strategies..., cit., 1355

${ }^{13}$ Schaffner, J.E. Community Cats..., cit., p. 84 and n.84, citing the American Society for the Prevention of Cruelty to Animal's use of "community cats" for all unowned cats.

${ }^{14}$ Feral cats in Switzerland are also sometimes referred to as "abandoned cats returned to the wild" ("chats abandonnés devenus sauvages"). The wild cat and the domestic cat are still closely related, and the Swiss animal welfare organization Protection des Animaux Suisse (PSA) has warned that the uncontrolled breeding of feral cats could pose threats to wild cats in the form of both rivalry for territory and inter-breeding (wild with domestic) - one reason that, as discussed in section 3, the PSA supports TNR for feral cats. Furrer, S. Des solitaires farouches, in L'Ami des Animaux (Protection Suisse des Animaux) 1/2019

${ }^{15}$ Protection Suisse des Animaux (PSA) and Union Suisse des Paysannes et des Femmes Rurales. Les chats à la ferme: Ensemble pour des chats sains (n.d.) [translated from the French: "les colonies incontrolées des chats"] http://www.protectionanimaux.com/publications/animaux_de_compagnie/infothek/chats_chiens/flyer_chats_ferme.pdf [Last consulted 9 July 2019]
} 
sterilize, vaccinate and return cats are concentrated in areas known to have a high-density [sic] of community cats." ${ }^{16}$ The article will use the term TNR to refer broadly to trap-neuter-return programs because this (or its equivalent in different languages) is the most commonly used acronym in many countries; further, not all TNR programs include vaccination routinely. However, the abbreviation "TNVR", or trap-neuter-vaccinatereturn, is also sometimes used in the literature. Lastly, brief mention will be made in places to an approach that is on the rise in the United States: shelter-neuter-return (SNR), whereby an animal shelter becomes directly involved in operating a TNR program. ${ }^{17}$

Disclaimers: the translation into English of legal texts cited throughout the article is not official and serves only to aid understanding in the scope of this work. The author is a volunteer with SOS Chats, one of the organizations interviewed, but has never participated in its TNR program, which is profiled in section 4.

\section{Section 2. TNR: General Discussion}

"TNR is the only ethical and scientific method that practically guarantees the five freedoms that must prevail to ensure animal welfare: freedom from hunger (balanced and adequate diet for the species), from thirst and from malnutrition; freedom from injury, disease and pain; freedom from stress, frustration and fear; freedom from physical discomfort; and freedom to express natural behavior."18

\subsection{Emergence and Growing Popularity of TNR Globally}

A recent article evaluating a 23-year TNR program in Key Largo, Florida captures succinctly several arguments often put forward in favor of TNR:

Trap Neuter Return (TNR) programs exist in large part to reduce population size and growth rate by decreasing reproduction. Reductions in population size are desirable due to concerns regarding wildlife predation, public health and nuisance factors. In addition to reducing population size or growth, TNR is also promoted as a method for improving cat welfare...TNR allows for the provision of veterinary care... and humane euthanasia for animals found to be suffering. It is also a method for promoting humane communities by avoiding euthanasia as a means of population control or nuisance abatement. ${ }^{19}$

Since the early $2000 \mathrm{~s}$, academic researchers, veterinarians and practitioners have published articles, including peer-reviewed works in scientific journals, providing evidence of the effectiveness of TNR in reducing feral cat populations in specific areas ${ }^{20}$ Research on TNR in various countries also suggests these programs can bring improvements in public attitudes toward community cats and can lower the incidence of

\footnotetext{
${ }^{16}$ Spehar, D.D., Wolf, P.J. Integrated Return-to-Field and Targeted Trap-Neuter-Vaccinate-Return Programs Result in Reductions of Feline Intake and Euthanasia at Six Municipal Animal Shelters, in Frontiers in Veterinary Science 6:77 (2019), 2

${ }_{17}$ Alley Cat Allies. Talking About Cats: Helpful Terms and Definitions. https://www.alleycat.org/resources/talking-about-catshelpful-terms-and-definitions/ [Last consulted 17 June 2019]

${ }^{18}$ Asociación de Veterinarios Abolicionistas de la Tauromaquia y del Maltrato Animal (AVATMA), Informe veterinario sobre las colonias felinas y su control por el método de Captura, Esterilización y Suelta (CES) (15 October 2016) https://avatma.org/2016/10/15/informe-veterinario-sobre-las-colonias-felinas-y-su-control-por-el-metodo-de-captura-esterilizaciony-suelta-ces/ [Last consulted 20 June 2019] [Translated from the Spanish: "El CES es el único método ético y científico que garantiza prácticamente las cinco libertades que deben prevalecer para garantizar el bienestar animal: Libres de hambre (dieta balanceada y adecuada para su especie), de sed, y de desnutrición; libres de lesión, de enfermedad y de dolor; libres de ansiedad, frustración, y miedo; libres de incomodidad y de molestias físicas; y libres de manifestar su comportamiento natural.”]

${ }^{19}$ Kreisler, R.E., Cornell, H.N., Levy, J.K. Decrease in Population and Increase in Welfare of Community Cats in a Twenty-Three Year Trap-Neuter-Return Program in Key Largo, FL: The ORCAT Program, in Frontiers in Veterinary Science 6:7 (2019)

${ }^{20}$ For example, from the U.S., see Nutter, F.B. Evaluation of a Trap-Neuter-Return Management Program for Feral Cat Colonies: Population Dynamics, Home Ranges, and Potentially Zoonotic Diseases. Ph.D. Thesis, North Carolina State University (Raleigh, N.C., 2005); Spehar, D.D., Wolf, P.J. A Case Study in Citizen Science: The Effectiveness of a Trap-Neuter-Return Program in a Chicago Neighborhood, in Animals, 8:14 (2018); Spehar, D.D., Wolf, P.J. An Examination of an Iconic Trap-Neuter-Return Program: The Newburyport, Massachusetts Case Study, in Animals, 7:81 (2017); Levy, J.K., Gale, D.W., Gale, L.A. Evaluation of a Long-term Trap-Neuter-Return and Adoption Program on a Free-roaming Cat Population, in Journal of the American Veterinary Medical Association 222:1 (1 January 2003); and Kreisler, R.E., Cornell, H.N., Levy, J.K. Decrease in Population...,cit. From outside the U.S., see, for example, Natoli, E. et al. Management of Feral Domestic Cats in the Urban Environment of Rome (Italy), in Preventive Veterinary Medicine 77 (2006); Change for Animals Foundation and Animais da Rua. Praia de Faro Dog and Cat Management Project. June 2015 Stage 2.2 Report; and Swarbrick, H., Rand, J. Application of a Protocol Based on Trap-Neuter-Return (TNR) to Manage Unowned Urban Cats on an Australian University Campus, in Animals 8:77 (2018)
} 
nuisance complaints lodged about the cats. ${ }^{21}$ An important reason for this is the effect that neutering has on cat behavior. As the Alliance for Contraception in Cats and Dogs (hereafter, ACC\&D) notes: "credible studies indicate that neutering reduces urine spraying and roaming in search of mates by male cats, and spaying eliminates estrous-associated behaviors in female cats, including aggression, vocalization and perhaps efforts to escape outdoors in order to mate." ${ }^{22}$ In addition, spaying and neutering improves the health of community cats, ${ }^{23}$ and TNR presents "an excellent opportunity" for feral and unowned cats "to receive additional veterinary care while they are being sterilized." ${ }^{24}$ Further, feral cats are generally not adoptable due to being poorly socialized to humans, and as free-roaming animals, they often cannot tolerate being confined in shelters that might otherwise represent a way-station to finding a human home. TNR therefore represents the only humane alternative for this population. Writing of the United States in 2009, Winograd stated: "To this day, feral cats have a near 100 percent death rate in those shelters that do not endorse or have a TNR program in place...Without TNR, all feral cats who enter shelters are killed." 25 By way of comparison, in Belgium, one source reported a kill rate of $49 \%$ for feral cats taken into shelters in $2016 .{ }^{26}$

It should be noted at the outset that the focus of the article is on TNR and feline population control, and not on TNR's impact on shelter intake and euthanasia rates. The latter has been the subject of a number of scientific journal articles, with recent studies from the U.S. in particular showing targeted TNR or SNR programs, combined with other elements such as adoption, reducing feline shelter intake and euthanasia rates significantly. ${ }^{27}$ The impact of TNR (or SNR) on these rates is, however, beyond the scope of this article (and it was not examined for the Swiss case.)

While it is unclear exactly when and where TNR got its start, several sources point to a scientific study published in 1984 on feral cat management in the United Kingdom as providing important early support for the practice. ${ }^{28}$ According to one overview of feral cats, "Annabell Washburn of Martha's Vineyard, Massachusetts, is generally credited with bringing the concept of Trap-Neuter-Return (TNR) to feral cat management in the United States in 1980." ${ }^{29}$ The same source cites the founding in 1990 of Alley Cat Allies, a US advocacy organization for cats with a major dedicated TNR program, as marking "the beginning of legitimacy for feral cats and of TNR as a control technique in the United States. ${ }^{30}$ The way TNR has developed over the years could be described as an organic process. It often starts with individual cat caregivers who sometimes "form networks with others" caring for cats, which in turn may form into a non-profit or "partner with existing grass-roots TNR programs. While it may take months (or years) to build the level of trust needed among the parties, these alliances can be extremely productive." ${ }^{31}$ This pattern repeats itself in multiple countries where TNR has been studied.

In 2013, Alley Cat Allies reported that over 330 local governments in the U.S. "incorporate TNR into their animal control policies and practices"; this figure did not include "the thousands of feral cat groups and

\footnotetext{
${ }^{21}$ McDonald, J.L., Farnworth, M.J. and Clements, J. Integrating Trap-Neuter-Return Campaigns into a Social Framework: Developing Long-Term Positive Behaviour Change Toward Unowned Cats in Urban Areas, in Frontiers in Veterinary Science (2018), 5: 258; Change for Animals Foundation and Animais da Rua. Praia de Faro Dog and Cat Management Project. June 2015 Stage 2.2 Report; Swarbrick, H., Rand, J. Application of a Protocol..., cit.; Dufau, A. Management of Urban Cats in Barcelona (April 2013) http://carocat.eu/wp-content/uploads/2014/10/Management-of-urban-cats-in-Barcelona.pdf; and Schaffner, J.E. Community Cats..., cit.

${ }^{22}$ Alliance for Contraception in Cats and Dogs. Contraception and Fertility Control..., cit.

${ }^{23}$ AVATMA. Informe veterinario sobre las colonias felinas..., cit.

${ }^{24}$ Alliance for Contraception in Cast and Dogs. Contraception and Fertility Control..., cit.

${ }^{25}$ Winograd, N.J. Redemption: The Myth of Pet Overpopulation and the No Kill Revolution in America (Almaden Books, 2007 ), 67

${ }^{26}$ Dufau, A. Feline Overpopulation in the EU: Abandonment and Urban Cats. Masters program in Animal Law \& Society. Universidad Autónoma de Barcelona. Powerpoint presentation, 15 February 2018

${ }^{27}$ See, for example, Edinboro, C.H., Watson, H.N., Fairbrother, A. Association between a Shelter-Neuter-Return Program and Cat Health at a Large Municipal Animal Shelter, in Journal of the American Veterinary Medical Association 248:3 (1 February 2016); Johnson, K.L., Cicirelli, J. Study of the Effect on Shelter Cat Intakes and Euthanasia from a Shelter Neuter Return Program of 10,080 Cats from March 2010 to June 2014, in PeerJ 2:e646 (2014); Levy, J., Isaza, N.M., Scott, K.C. Evaluation of High-Impact Targeted Trap-Neuter-Return and Adoption of Community Cats on Cat Intake to a Shelter, in The Veterinary Journal 201 (2014); and Spehar, D.D., Wolf, P.J. Integrated Return-to-Field and Targeted..., cit.. Note that the use of "euthanasia rates" here reflects its use in the journal articles cited, but it is a controversial term, as it refers to putting to death animals that are often healthy. As Schaffner asserts, "The killing of a healthy animal is just that, killing, not euthanasia." (Schaffner, J.E. Community Cats..., n.139).

${ }^{28}$ See, for example, Hamilton, F.E. Leading and Organizing Social Change for Companion Animals. Anthrozoös 23:3 (2010), 288, citing Neville, P., Remfry, J. Effects of Neutering on Two Groups of Feral Cats, in The Veterinary Record 114:18 (1984), 447-450

${ }^{29}$ Slater, M.R., Shain, S. Feral Cats: An Overview..., cit., 43, citing Berkeley, E.P. Feral Cats. Cat Fancy, (1990) July, 20-27

${ }^{30}$ Ibid., 44. Slater and Shain also cite "several other grass-roots organizations" in the U.S. that they call "early pioneers in the TNR movement", dating mostly to the late 1980s and early 1990s (Ibid.) Schaffner cites TNR as "originating in England in the 1950s and introduced in the United States in the 1990s" (Schaffner, J.E. Community Cats...cit., 74).

${ }^{31}$ Slater, M.R., Shain, S. Feral Cats: An Overview...cit., 49
} 
countless individual caregivers conducting TNR privately" in that country. ${ }^{32}$ As of this writing, Alley Cat Allies' "ongoing survey of cities and counties reveals that by January 2017, more than 600 local governments [in the U.S.] have implemented TNR ordinances and policies. From 2003 to 2013 the number increased tenfold, and that number continues to increase." 33 Interestingly, the organization's research has shown that a range of local US governments - from liberal to conservative - support TNR. ${ }^{34}$ In addition, municipal (staterun) animal shelters in a number of major US cities have participated in community cat programs that integrate TNVR or SNR. ${ }^{35}$ In 2017, the American Bar Association passed a resolution supporting TNVR programs for free-roaming cats, and called on states and local governments to "adopt laws and policies, to allow the implementation and administration of Trap-Neuter-Vaccinate-Return programs for community cats." 36

Over roughly the same period (that is, beginning largely in the 1990s), TNR has also become wellestablished in other countries, and in several instances is supported by law. For example, it has been conducted for almost three decades in Italy, helped along by the passage in 1991 of national Law No. 281 on controlling feral cats through a "no-kill policy." 37 The Italian case showed early and crucial support from the state for TNR, in both the national law and a subsequent regional law in Lazio (where Rome is located). Natoli et al, reviewing 30 years of colony management of urban free-roaming cats in Rome, credit these laws with introducing "a revolutionary perspective" based on "the cats' right to live free and safe; the compulsory neutering of cats" by governmental veterinary services and "the institutionalization of cat caretakers." 38 Along somewhat similar lines, in 2004, the Israeli Supreme Court banned the use of culling to control feral cats, after which TNR became "frequently used"; in fact, "local municipalities and the Israeli Ministry of Agriculture and Rural Development invest millions of dollars in TNR actions each year." 39

In recent years, several municipal governments in Spain, including Barcelona, Ceuta, Zaragoza, ${ }^{40}$ and Madrid $^{41}$ have passed ordinances that promote the humane control of cat colonies through programs that include TNR. Most notably, the Barcelona Ordinance of 2014 on the Protection, Possession and Sale of Animals goes into detail on cat colony management. Through this law, the city formally promotes the existence of "controlled feral cat colonies" ("les colònies controlades de gats ferals") and supports the nonprofit entities that take care of them. ${ }^{42}$ In France, as Dufau notes, Law 99-05 of 1999 provided mayors with "a management alternative to the model of 'capture-shelter-transfer or sacrifice': the model of "capturesterilization and identification and return." "43 And following a January 2015 decree, mayors must first try to implement cat colony management programs before trapping and bringing colony cats to a shelter, thus making TNR the "first choice for managing feline overpopulation in France." 44 The French municipal governments of Marseille, Nice and Toulouse "have set in motion the management of cat colonies," taking up the TNR option offered by Law 99-05, and have signed formal accords, in some cases since the early 2000s,

\footnotetext{
${ }^{32}$ Holtz, E. Trap-Neuter-Return Ordinances and Policies in the United States: The Future of Animal Control. Law \& Policy Brief (Bethesda, MD: Alley Cat Allies, January 2013). Spehar and Wolf point out that the U.S. "has no national laws governing the management of free-roaming domestic cats", so the issue is governed at state and municipal levels. Spehar, D.D., Wolf, P.J. Integrated Return-to-Field and Targeted..., cit.

33 Alley Cat Allies. Cats and the Law (n.d.) https://www.alleycat.org/our-work/cats-and-the-law/ [Last consulted 9 May 2019]

${ }^{34}$ Holtz, E., Trap-Neuter-Return Ordinances..., cit., 5

${ }^{35}$ See Spehar, D.D., Wolf, P.J. Integrated Return-to-Field and Targeted..., cit. and Edinboro, C.H., Watson, H.N., Fairbrother, A. Association between a Shelter-Neuter-Return..., cit.

${ }^{36}$ American Bar Association. 102B Resolution. August 14-15, 2017 and Cassens Weiss, D. Trap-Neuter-Vaccinate-Return Programs for Community Cats Backed by ABA Delegates, in ABA Journal. 14 August 2017

http://www.abajournal.com/news/article/trap_neuter_vaccinate_return_community_cats_aba_delegates [Last consulted 4 May 2019]

${ }^{37}$ Natoli, E. et al. Management of Feral Domestic Cats..., cit., 181

${ }^{38}$ Natoli, E. et al. Evaluation of Unowned Domestic Cat Management in the Urban Environment of Rome after 30 Years of Implementation of the No-Kill Policy (National and Regional Laws), in Frontiers in Veterinary Science 6:31 (2019)

39 Gunther, I., Raz, T., Even Zor, Y., Bachowski, Y., Klement, E. Feeders of Free-Roaming Cats: Personal Characteristics, Feeding Practices, and Data on Cat Health and Welfare in an Urban Setting of Israel, in Frontiers in Veterinary Science 3:21 (2016)

${ }^{40}$ Dufau, A., Estatuto jurídico del gato callejero en España, Francia y Reino Unido (Tirant Lo Blanch 2017), 83-85; see also Ajuntament de Barcelona. Benestar Animal. Area de Ecologia, Urbanisme i Mobilitat Gats http://ajuntament.barcelona.cat/benestaranimal/ca/gats [Last consulted 11 July 2019]; and Gobierno de Ceuta. Sanidad aprueba las normas de funcionamiento para el control de colonias de gatos. 13 May $2016 \mathrm{http}: / /$ www.gobiernodeceuta.es/index.php/10-sanidady-consumo/8307-sanidad-aprueba-las-normas-de-funcionamiento-para-el-control-de-colonia-de-gatos [Last consulted 11 July 2019]

${ }^{41}$ Dufau, A. Feline Overpopulation in the EU..., cit.

${ }^{42}$ Barcelona, Ordenança de Protecció, Tinència i Venta d'Animals, Diputació Barcelona, 15 de setembre de 2014, Article 28 https://bop.diba.cat/scripts/ftpisa.aspx?fnew?bop2014\&09/022014022793.pdf\&1 For more on Barcelona as a model city in terms of cat colony management, see Dufau, A. Management of Urban Cats..., cit.

${ }^{43}$ Dufau, A., Estatuto jurídico del gato callejero...cit., 50 [translated from the Spanish: "una alternativa de gestión al modelo de ‘captura-acogida-cesión o sacrificio': el modelo de ‘captura-esterilización e identificación y retorno.”']

${ }^{44}$ Ibid., 52 [translated from the Spanish: "la primera alternativa de gestión de la superpoblación felina en Francia”]
} 
with NGOs that carry out TNR. ${ }^{45}$ More recently, in 2018 a Chilean regulation on responsible animal ownership made TNR (of both community cats and dogs) mandatory for its municipalities, which are given latitude to enter agreements with animal protection organizations to carry out the operations. ${ }^{46}$ And as section 4 discusses in detail, multiple NGOs in Switzerland have undertaken TNR campaigns for over 20 years, with individuals practicing it since well before that.

In addition, TNR as a method of population control has the support of many animal welfare organizations ${ }^{47}$ as well as veterinary associations in various countries. ${ }^{48}$ Myriad NGOs around the world have formed dedicated TNR programs. ${ }^{49}$ In terms of the wider public, sources point to rising support for TNR and declining tolerance of methods such as capturing and killing feral cats to reduce their population. ${ }^{50}$ What is more, while there is evidence that "complete eradication" of feral cats through trap-and-kill can work on islands, such programs "often require years to accomplish and hundreds of hours of work and are only successful in closed populations where no new cats can arrive." ${ }^{11}$ Otherwise, trapping and killing can lead to a so-called vacuum effect, whereby "new cats will move in from nearby areas, and survivors of the removal program will continue to reproduce until maximum carrying capacity is reached again." 52 Just as important as a method's effectiveness is the question of whether it is considered morally acceptable by society. Culling is likely to be untenable due to public rejection of the mass killing of healthy animals. As Boone notes, "public opinion in developed countries is unlikely to support a total abandonment of TNR in favor of widespread cat management using lethal methods." 53

\footnotetext{
${ }^{45}$ Ibid., 89-92 [translated from the Spanish: "han puesto en marcha la gestión de colonias de gatos"]

${ }^{46}$ Chile, Article 40, Decreto 1.007, Reglamento que establece la forma y condiciones en que se aplicarán las normas sobre tenencia responsable de mascotas y animales de compañía y determina las normas que permitirán calificar a ciertos especímenes caninos como potencialmente peligrosos (Regulation establishing the form and conditions under which the norms on responsible ownership of pets and companion animals will be applied and determining the standards that will qualify certain canine specimens as potentially dangerous), published 17 August $2018 \mathrm{https} / /$ www.leychile.cl/Navegar?idNorma=1121980\&idParte=0\&idVersion= [Last consulted 2 July 2019]. Decreto 1.007, follows on Chile's 2017 Ley 21.020 sobre tenencia responsable de mascotas y animales de compañía (Law on Responsible Pet Ownership, also known as the "Ley Cholito", published 2 August 2017) https://www.leychile.cl/Navegar?idNorma=1 106037 [Last consulted 2 July 2019] I am grateful to Molly Armus, Staff Attorney, Alley Cat Allies, for pointing me to this regulation in a written communication, 1 July 2019.

47 Examples include: American Humane Association. Animal Welfare Policy and Position Statements (2012) http://www.americanhumane.org/app/uploads/2016/08/animal-position.pdf [Last consulted 9 May 2019]; American Society for the Prevention of Cruelty to Animals (ASPCA). Position Statement on Community Cats and Community Cat Programs (n.d.) https://www.aspca.org/about-us/aspca-policy-and-position-statements/position-statement-community-cats-and-community-cat [Last consulted 9 May 2019]; Humane Society of the United States (HSUS). Our Position on Cats. https://www.humanesociety.org/resources/our-position-cats\#unowned_cats (n.d.) [Last consulted 9 May 2019]; and British Columbia Society for the Prevention of Cruelty to Animals. Position Statement on Cat Welfare (n.d.) https://spca.bc.ca/programsservices/leaders-in-our-field/position-statements/position-statement-on-cat-welfare/ [Last consulted 9 May 2019]. For a fuller list of US animal welfare organizations that support TNR, see Schaffner, J.E. Community Cats..., cit., n. 20. See Winograd, N.J. Redemption...cit., for a harsh critique of major US animal welfare organizations' earlier rejection of TNR in favor of killing feral cats.

${ }^{48}$ Association of Shelter Veterinarians. Position Statement. Trap-Neuter-Return of Free-Roaming \& Community Cats (April 2015) https://www.sheltervet.org/assets/docs/position-statements/trapneuterreturn.pdf [Last consulted 9 May 2019]; AVATMA, Informe veterinario...cit.; Grupo de Especialidad de Medicina Felina de la Asociación de Veterinarios Españoles Especialistas en Pequeños Animales (GEMFE-AVEPA). Posicionamiento GEMFE-AVEPA sobre las colonias felinas urbanas (n.d.) https://avepa.org/pdf/GRUPOSTRABAJO/POSICIONAMIENTO_Colonias_Felinas.pdf [Last consulted 9 May 2019]. Wolf and Schaffner write that "in 2016 the American Veterinary Medical Association (AVMA) shifted its official position on the issue in a direction more favorable to TNR" to where it now "encourages the use of non-lethal strategies as the initial focus for control of freeroaming abandoned and feral cat populations" (Wolf, P.J., Schaffner, J.E. The Road to TNR: Examining Trap-Neuter-Return through the Lens of our Evolving Ethics, in Frontiers in Veterinary Science 5:341 (2019))

${ }^{49}$ Examples include Alley Cat Allies, Cats Protection, Change for Animals Foundation, Network for Animal Protection and Vier Pfoten.

${ }^{50}$ A 2007 poll by Harris Interactive for Alley Cat Allies found that "an overwhelming majority of Americans believe that leaving a stray cat outside to live out his life is more humane than having him caught and put down." (Chu, K., Anderson, W. US Public Opinion on Humane Treatment of Stray Cats. Law \& Policy Brief (Bethesda, MD: Alley Cat Allies, September 2007)). In 2017 Alley Cat Allies commissioned another national poll by Harris Interactive, which found that " 84 percent of Americans prefer that their community use tax dollars to adopt sterilization as its cat control policy instead of bringing cats found outdoors into shelters to be killed." (Molly Armus, Staff Attorney, Alley Cat Allies, written communication to author, 3 April 2019). Wolf and Schaffner write that "the results of public opinion surveys concerning preferred methods of community cat management show strong support for TNR" and "little public support for lethal management methods" (Wolf, P.J., Schaffner, J.E. The Road to TNR..., cit.). Hamilton also reports on how his research "suggest[s] that no municipality can afford, either economically or politically, to continually euthanize the high number of cats that flow into the system" (Hamilton, F.E. Leading and Organizing Social Change..., cit., 288).

${ }^{51}$ Slater, M.R., Shain, S. Feral Cats: An Overview..., cit., 48

${ }^{52}$ Ibid., citing Tabor, R. The Wild Life of the Domestic Cat (London, 1983). See also Lazenby, B.T., Mooney, N.J., Dickman, C.R. Effects of Low-Level Culling of Feral Cats in Open Populations: A Case Study from the Forests of Southern Tasmania, in Wildlife Research 41:5 (2014), 407-420

${ }^{53}$ Boone, J.D. Better Trap-Neuter-Return for Free-Roaming Cats: Using Models and Monitoring to Improve Population Management,
} 
Indeed, Wolf and Schaffner attribute TNR's growing popularity to a "profound shift away from an anthropocentric utilitarian ethical framework" - that is, one based on trapping and killing community cats "toward a zoocentric virtue-based ethical framework that recognizes the intrinsic value of animals beyond any instrumental value to humans and our moral obligation to treat them with compassion." ${ }^{4}$ One could go further and underscore that feline overpopulation stems in large part from human actions, such as abandonment of cats and allowing intact pets to roam and breed outdoors. ${ }^{55}$ Therefore we have a "moral obligation" not only to treat community cats with compassion, as Wolf and Schaffner put it, but also to change our own behavior in order to fix the problem. In this sense, catch-and-kill might indeed be anthropocentric in its focus on getting rid of cats for the benefit of humans, but it is blind to the human responsibility aspect of feline overpopulation - and any solution that does not recognize this aspect is destined to fail in the long term.

Before turning to key criticisms, it is important to acknowledge, as have many practitioners and experts, that TNR is only one part of managing feline overpopulation. This is made clear in numerous articles that examine the importance and impact of combining TNR with other components such as intensive adoption of socializable cats, behavior management and counseling for owners or residents, legal reform, ongoing monitoring of cat colonies and other components. ${ }^{56}$ It is also recognized by animal welfare organizations that recommend a multi-faceted approach to feline overpopulation and that offer a range of tools to communities, shelters, local authorities, veterinarians and others concerned about community cats. ${ }^{57}$ And it is summarized succinctly by Harry Eckman, whose Change for Animals Foundation has carried out a recent successful TNR program in Praia de Faro, Portugal (see section 5). Eckman argues that a comprehensive cat population management plan includes many tools: education, legislation, registration and identification of cats, TNR, shelters and rehoming centers, vaccination and treatment, and, where necessary to end suffering, euthanasia. ${ }^{58}$ As Dufau notes, TNR alone is not cat colony management; it is an essential part of it, but not sufficient. ${ }^{59}$

\subsection{Criticisms and Challenges}

Despite TNR's growth in popularity as a mechanism for addressing feline overpopulation, it continues to face controversy. ${ }^{60}$ Critics of TNR include those arguing that it is cruel; that it contributes to public health problems; that it exacerbates the problem of outdoor cats killing wildlife; and that it is of questionable effectiveness in comparison to other methods of reducing feral cat populations. A recent defense of TNR by Schaffner provides a detailed and well-argued rebuttal of these and other criticisms of, or concerns about, TNR, so it will be cited at length here, along with several other sources.

First, in response to claims that TNR is inhumane or cruel because it is predicated on leaving cats outdoors where they could be endangered or live in misery, Schaffner points to studies providing evidence that community cats can and do thrive outside. ${ }^{61}$ For his part, Winograd underscores the irony of making the argument, as some opponents of TNR do, that feral cats should be euthanized because they are "better off dead" than living outside; as he writes, "There is no question that cats living outside face risks. But life is

in Journal of Feline Medicine and Surgery 17 (2015), 800

${ }^{54}$ Wolf, P.J., Schaffner, J.E. The Road to TNR..., cit., 4

55 This point has been made by many observers: for example, Robertson, S. A. Review of Feral Cat Control, in Journal of Feline Medicine and Surgery 10 (2008), 367 and 373; Slater, M.R., Shain, S. Feral Cats: An Overview..., cit., 50; and Protection Suisse des Animaux. Détention de chats conforme à l'espèce: Guide pratique (November 2012), 11 www.protectionanimaux.com/publications/animaux_de_compagnie/docs/detention_chats.html [Last consulted 27 May 2019]

${ }^{56}$ See, for example, Levy, J., Isaza, N.M., Scott, K.C. Evaluation of High-Impact...cit.; Levy, J.K., Gale, D.W., Gale, L.A. Evaluation of a Long-term..., cit.; Spehar, D.D., Wolf, P.J. An Examination of an Iconic..., cit.; McDonald, J.L., Farnworth, M.J., Clements, J. Integrating Trap-Neuter-Return..., cit.; and Schaffner, J.E. Community Cats..., cit.

${ }^{57}$ Examples include CAROcat (in Europe) and Alley Cat Allies (in the U.S.) CAROcat's website notes: "The only way to stop feline overpopulation is to adopt a Europe-wide, systematic, multidisciplinary and comprehensive approach to the problem: a combination of measures including the elements of systematic cat birth control in place of killing animals, veterinary prevention, Identification and Registration, information, education, political and legal activities.” CAROcat. About Us. Web page: http://carocat.eu/about-us/ [Last consulted 13 May 2019.] In addition to its TNR programs, Alley Cat Allies works on community change, veterinary education, strengthening networks of feral cat advocates and caregivers, and legal and shelter reform. See Alley Cat Allies. Web page: https://www.alleycat.org/our-work/ [Last consulted 13 May 2019]

58 Eckman, H. "Cat Population Management: The Human Element." Presentation, Jornadas Felinas Europeas 2016 (26 November 2016, Barcelona), available at: https://www.youtube.com/watch?v=tWp7XqC_RUc [Last accessed 18 June 2019]

${ }^{59}$ Dufau, A. Feline Overpopulation in the EU..., cit.

${ }^{60}$ Wolf, P.J., Schaffner, J.E. The Road to TNR..., cit.

${ }^{61}$ Schaffner, J.E. Community Cats..., cit., n35 and n36, citing Wallace, J.L., Levy, J.K. Population Characteristics of Feral Cats Admitted to Seven Trap-Neuter-Return Programs in the United States, 8 J. Feline Med. \& Surgery (2006) 279, 282, and Chu, K., Anderson, W.M., US Public Opinion on Humane..., cit., 3. See also Scott, K.C., Levy, J.K., Crawford, P.C. Characteristics of FreeRoaming Cats Evaluated in a Trap-Neuter-Return Program, in Journal of American Veterinary Medical Association. 221:8 (15 October 2002) and Winograd, N.J. Redemption..., cit., 72-73. 
about risks. The contention of TNR opponents that we stop the cat from possibly suffering or possibly dying by killing the cat ourselves is an irreconcilable contradiction." ${ }^{62}$ Writing in 2004, Levy and Crawford noted already that "the recent growth of the 'no-kill' movement has caused some leaders to reexamine traditional beliefs that euthanizing large numbers of healthy animals to prevent potential suffering or as a method of population control can be compatible with the values of a humane society." ${ }^{63}$ Further, based on studies indicating decent health conditions among feral cats both before and after sterilization in TNR programs, the same authors write:

Although TNR may not meet the gold standard of care desired for pet cats, it appears that sterilized feral cats can enjoy an extended period of good quality of life while their population dwindles by adoption or natural attrition. As such, is it not necessary to perform prophylactic euthanasia of feral cats simply because they do not share a human address. ${ }^{64}$

In a similar vein, Alley Cat Allies asserts that community cats "live full, healthy lives with their feline families, called colonies, in their outdoor homes...Community cats are used to living outdoors, and are naturally skilled at finding shelter and food on their own. Studies show community cats are just as healthy as indoor cats, with equally low disease rates." ${ }^{65}$ Taking this a step further, cat colonies deserve humane treatment but they are not simply animals to be pitied. Indeed, the "R" in TNR is an acknowledgment that these cats can thrive if released back to the places where they were trapped. And because TNR is practiced on healthy cats, as Schaffner notes, "there is no reason to believe that returning them to the original location would subject them to pain, suffering or cruelty". ${ }^{66}$

Regarding concerns that community cats are potential vectors for diseases that could endanger public health, Schaffner argues that "the claims are often exaggerated," citing sources calling these claims into question and suggesting that managing community cats could, on the contrary, provide a way to lower risks to human populations. ${ }^{67}$ The Spanish veterinary association, Asociación de Veterinarios Abolicionistas de la Tauromaquia y del Maltrato Animal (hereafter, AVATMA), states of TNR: "the control of colonies under the TNR method will allow for greatly reducing the public health concerns that may arise around domestic cats." 68 And while Gunther et al argue that free-roaming cats" "potential to transmit several zoonotic diseases...has been well described in the literature," ${ }^{69}$ some of the disease risks that they cite (such as rabies, toxoplasmosis and flea-borne typhus) are ones for which Schaffner and others ${ }^{70}$ specifically supply counter-evidence. For rabies in particular, Schaffner notes that TNR programs in the U.S. "evaluate cats and return only healthy cats after vaccinating them for rabies, thereby reducing, for years, the risk of rabies in the returned cats." ${ }^{11}$ Further, she points out, "community cats, many unsocialized to humans, rarely have contact with humans, thus making disease transmission highly unlikely." "22 Levy and Crawford argue that "[t]aken together, reports of transmissible diseases in feral cats indicate that, for many diseases, feral cats do not have a greater impact than free-roaming pet cats", and in any case, "it is clear that widespread vaccination against zoonotic and feline diseases coupled with population reduction via sterilization will address many public health concerns surrounding domestic cats." 73

To those opposing TNR - and sometimes espousing killing feral cats instead - due to claims that community cats are killing wildlife, Schaffner demonstrates that many of these claims have been based on

\footnotetext{
${ }^{62}$ Winograd, N.J. Redemption..., cit. 72 \& 73 (emphasis in original)

${ }^{63}$ Levy, J.K., Crawford, P.C. Humane Strategies..., cit., 1357

${ }^{64}$ Ibid., 1359

${ }^{65}$ Alley Cat Allies. Just the Facts: Community Cats. Web page: https://www.alleycat.org/resources/the-truth-about-community-cats/ [Last consulted 14 April 2021]

${ }^{66}$ Schaffner, J.E. Community Cats..., cit., p. 97.

${ }^{67}$ Schaffner, J.E. Community Cats..., cit., 88-89. See also Humane Society of the United States. Managing Community Cats: A Guide for Municipal Leaders. 2014, 19, and Alley Cat Allies. Feral Cats and the Public: A Healthy Relationship. https://www.alleycat.org/resources/feral-cats-and-the-public-a-healthy-relationship/ (2016) [Last consulted 17 May 2019], which cites several scientific studies that find feral cat colonies do not pose a risk to human health.

${ }^{68}$ AVATMA. Informe veterinario sobre las colonias felinas..., cit. [Translated from the Spanish: "el control de las colonias bajo el método CES permitirá reducer enormemente las preocupaciones sobre la salud pública que pueden surgir alrededor de los gatos domésticos."]

${ }^{69}$ Gunther, I., Raz, T., Even Zor, Y., Bachowski, Y., Klement, E. Feeders of Free-Roaming Cats..., cit., citing various studies.

${ }^{70}$ Alley Cat Allies. Feral Cats and the Public..., cit. [Last consulted 17 May 2019]

${ }^{71}$ Schaffner, J.E. Community Cats..., cit., 88. According to a 2012 study by the Centers for Disease Control cited by Schaffner, only two cases of rabies in humans "have been attributed to cats" since 1960.

${ }^{72}$ Schaffner, J.E. Community Cats..., cit., 88

${ }^{73}$ Levy, J.K., Crawford, P.C. Humane Strategies..., cit., 1357
} 
"flawed science." 74 Bradshaw also notes that the evidence around the impact of cats on wildlife is "equivocal". ${ }^{75}$ The wildlife concerns are complex, and beyond the scope of this article. TNR proponents are on perhaps strongest ground, however, when they point out that one of TNR's central aims, which is to reduce feral cat populations, is in alignment with conservationists' goal of protecting wildlife from predation by cats. ${ }^{76}$ What is more, there are prospects for animal welfare and wildlife conservationist groups to work together on specific areas such as better data collection to measure the impact of TNR on cat populations. ${ }^{77}$

Regarding TNR's effectiveness in comparison to other (humane) methods to control community cat populations, it is worth noting that the use of non-surgical, contraceptive options has been the subject of discussion in recent years. A 2013 report by the ACC\&D noted that "as permanent non-surgical options such as Esterilsol...emerge, they can be expected to play increasing roles in community-based population projects that now rely on surgery." 78 For its part, Alley Cat Allies acknowledges that "there are some promising contraceptive drugs and vaccines" on the horizon but that, at present, these are in the research stage, and surgery remains the safest option for sterilizing cats. ${ }^{79}$ In addition, a 2013 study by McCarthy et al presented evidence from a simulation model that Trap-Vasectomy-Hysterectomy-Release (TVHR) was significantly more effective than TNR (or lethal control) in reducing feral cat population size. ${ }^{80} \mathrm{In}$ response, the ACC\&D published a statement calling the study's methodology into question, noting that "some of the results presented by McCarthy et al are not consistent with results obtained in our own modeling study." 81 They add that it is "an important consideration that TVHR would likely not address nuisance behaviors, a common reason residents are intolerant of cats and population management efforts are undertaken, and that results seemed to be achieved in this model at the expense of cat welfare." 82

A further humane option, relocation of feral cats - that is, trapping them and moving them to another spot - is not considered feasible as a solution to feline overpopulation because of the "vacuum effect" described earlier. According to Slater and Shain, relocation "is a time-consuming process complicated by the need to locate suitable release sites, and there are relatively limited data on success of relocation." 83 In addition, Alley Cat Allies argues that relocation "endangers cats' lives and causes them undue stress and suffering" 84 and should be used only as a last resort, for example if a site where community cats live is being demolished.$^{85}$ One form of relocation is to remove feral cats and place them in sanctuaries. This has been tried

\footnotetext{
${ }^{74}$ Schaffner, J.E. Community Cats..., cit., 85-88. See also Winograd, N.J. Redemption..., cit., 76-79

${ }^{75}$ Bradshaw, J. Cat Sense..., cit., 244. Bradshaw points to studies showing that "habitat degradation, and not cats, may have been the major factor" causing wildlife decline in Australia (cit., 245). Likewise, in the United States, National Public Radio reported in September 2019 that a recent study by ornithologists concluded that the "main culprits" in the drop in certain bird populations in North America since 1970 was "probably the loss of their natural habitat, with increased urbanization and agriculture." Greenfieldboyce, N. North America Has Lost 3 Billion Birds, Scientists Say. National Public Radio. 19 September 2019.

${ }^{76}$ Schaffner analyzes a lawsuit filed in 2016 in New York by a conservation organization that alleges community cat management near nesting sites of a threatened bird species, the Piping Plover, is in violation of the US Endangered Species Act (ESA). In her analysis, Schaffner demonstrates the flawed reasoning of the suit, and underscores that TNVR operations "are designed to reduce the population of cats" in the area in question, which is "consistent with protecting the Piping Plovers." Schaffner, J.E. Community Cats..., cit., 106. Elsewhere, Schaffner writes, "most all agree, animalists and conservationists alike, that free-roaming cats may harm individual birds (and other free-living animals) and that it would be best, for the birds and the cats, to reduce the population of freeroaming cats." Schaffner, J.E. Cat Wars: The Devastating Consequences of a Dangerous Book, review of P. Marra and C. Santella, Cat Wars: The Devastating Consequences of a Cuddly Killer, in Journal of Animal Ethics 8:2 (2018), 246.

${ }^{77}$ One such example of collaborative work is described in Lisnik, K. Reconcilable Differences: Wildlife Biologist Helps Chart a New Path for Cat Advocates and Conservationists. Animal Sheltering Magazine (Fall 2017) https://www.animalsheltering.org/magazine/articles/reconcilable-differences-0 [Last consulted 16 May 2019]

78 Alliance for Contraception in Cats and Dogs. Contraception and Fertility Control..., cit. For one review of research on immunocontraception, see Levy, J.K. Contraceptive Vaccines for the Humane Control of Community Cat Populations, in American Journal of Reproductive Immunology 66 (2011), 63-70

${ }^{79}$ Alley Cat Allies. Non-surgical Sterilization for Cats? Not Yet. https://www.alleycat.org/resources/non-surgical-sterilization-forcats-not-yet/ [Last consulted 14 June 2019] See also Hiby, E., Eckman, H., MacFarlaine, I. Cat Population Management in D.C. Turner and P. Bateson (Eds.), The Domestic Cat: The Biology of its Behaviour ( $3^{\text {rd }}$ ed.) (Cambridge University Press, 2014), p. 221.

${ }^{80}$ McCarthy, R, Levine, S.H., Reed, J.M. Estimation of Effectiveness of Three Methods of Feral Cat Population Control by Use of a Simulation Model in Journal of the American Veterinary Medical Association 243:4 (15 August 2013)

81 Alliance for Contraception in Cats and Dogs. Position Statement: Modeling Study Advocating Use of Vasectomies and Hysterectomies in Feral Cat Management (2014) https://www.acc-d.org/resource-library/position-statements/acc-d-positionstatement-on-mccarthy-et-al [Last consulted 14 June 2019]. See also Alley Cat Allies. Trap-Vasectomy-Hysterectomy-Return (TVHR) Is No Substitute for Trap-Neuter-Return (TNR) https://www.alleycat.org/resources/trap-vasectomy-hysterectomy-returntvhr-is-no-substitute-for-trap-neuter-return-tnr/ [Last consulted 14 June 2019]

${ }^{82}$ Alliance for Contraception in Cats and Dogs. Position Statement: Modeling Study..., cit.

${ }^{83}$ Slater, M.R., Shain, S. Feral Cats: An Overview..., cit., 48

${ }^{84}$ Alley Cat Allies. Why Trap-Neuter-Return..., cit.

85 Alley Cat Allies. Relocation: A Last Resort. https://www.alleycat.org/community-cat-care/relocation-the-last-resort/ [Last consulted 10 July 2019]
} 
in various places, but a number of experts conclude that these programs cannot be scaled to the level needed to control feral cat populations. ${ }^{86}$

Finally, in response to the financial implications of spaying and neutering community cats, Schaffner cites sources showing that TNR is less expensive than lethal methods of feral cat control. ${ }^{87}$ In addition, "TNVR often is conducted by nonprofits and individual volunteers costing the government little or nothing." ${ }^{88}$ This point is emphasized by TNR practitioners in many countries, and will be revisited in the context of the Swiss case in section 4.

For the reasons outlined, this article takes the position that, at present, TNR is the most appropriate that is, both humane and effective - approach to managing feral and stray cat populations. That said, the practice continues to face challenges, several of which will be discussed at length in sections 4 and 5, as well as valid criticisms of its weak points. In the latter category, three are highlighted briefly here. First, to be effective, TNR must be carried out in a targeted fashion, which means it must be applied systematically in a clearly defined area, as opposed to taking a "scattershot" approach. ${ }^{89}$ This includes trapping every cat in a specific area, not just the cats that are easiest to catch. One criticism, however, is that it is not clear how widely this is practiced. Recent articles present strong evidence that targeted TNR is associated with lowering shelter intake and euthanasia, ${ }^{90}$ thus showing the benefits, beyond population control, of a systematic approach carried out in a circumscribed area. The issue of targeted TNR will be taken up again briefly in relation to the Swiss case, as an operational aspect that must be strengthened. In a related vein, critics note that, to be effective, TNR must be carried out on a larger and more systematic scale than is often done. ${ }^{91}$ Although some TNR programs are making efforts to address this point, ${ }^{92}$ this, too, remains a persistent criticism and an important challenge.

A second criticism is that the collection, standardization and analysis of data and performance metrics remain weak links in many TNR programs. ${ }^{93}$ In this vein, Schaffner argues that proponents of TNR must "critically study and document" its efficacy. ${ }^{94}$ Not only will this be useful in pushing back against critics; demonstrations of success can also win over those in a position to advance TNR on a municipal scale. ${ }^{95} \mathrm{~A}$ number of sources provide guidance and suggestions on TNR data collection and analysis. ${ }^{96}$ Better data can, of course, also help practitioners to carry out the above-mentioned targeted TNR, since "through an

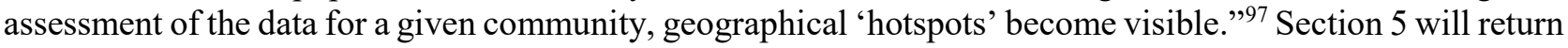
to the issue of data in relation to TNR in Switzerland.

Third, it seems to be an open question whether TNR, in providing ongoing food and care to community cats, might encourage abandonment by some cat owners if they think their cats will be taken care of. Schaffner counters this criticism with a reasonable argument: "it is difficult to imagine a responsible owner abandoning their cat because their neighbor is feeding community cats. Arguably, if an irresponsible owner wants to abandon their cat, they will do so with or without knowledge that the cat might be cared for by a caregiver." 98 Nonetheless, the possibility that TNR encourages abandonment is raised even in studies that point to the

\footnotetext{
${ }^{86}$ Levy, J.K., Crawford, P.C. Humane Strategies..., cit., 1357. See also Slater, M.R., Shain, S. Feral Cats: An Overview..., cit., 48

${ }^{87}$ Schaffner, J.E. Community Cats..., cit., n.44, n.45, n.47. See also Alley Cat Allies. Why Trap-Neuter-Return..., cit.

${ }^{88}$ Ibid., 79

${ }^{89}$ On the identification of target populations for TNR, see Boone, J.D. Better Trap-Neuter-Return...cit., 806

${ }^{90}$ Levy, J., Isaza, N.M., Scott, K.C. Evaluation of High-Impact..., cit. and Spehar, D.D., Wolf, P.J. Integrated Return-to-Field and Targeted..., cit.

${ }^{91}$ Robertson, S. A. Review of Feral Cat Control..., cit. and Boone, J.D. Better Trap-Neuter-Return..., cit.

${ }^{92}$ For example, Spehar and Wolf recently examined the results of TNVR at six municipal shelters in the U.S., addressing in part the past criticism that TNVR "has been historically conducted on a limited scale" (Spehar, D.D., Wolf, P.J. Integrated Return-to-Field and Targeted..., cit.

${ }^{93}$ See Boone, J.D. Better Trap-Neuter-Return..., cit. Spehar and Wolf point to numerous sources that underscore the need for "professionalization and standardization of TNR data collection and assessment practices" (Spehar, D.D., Wolf, P.J. An Examination of an Iconic..., cit. See also Edinboro, C.H., Watson, H.N., Fairbrother, A. Association between a Shelter-Neuter-Return..., cit. and Spehar, D.D., Wolf, P.J. A Case Study in Citizen Science...cit.

${ }^{94}$ Schaffner, J.E. Community Cats..., cit., 90

95 To give one small example, a TNR project that succeeded in bringing about a decline in shelter intake in Kentucky led a councilwoman to sponsor a "TNR-enabling ordinance" that was passed by the local government. Humane Society of the United States. Managing Community Cats..., cit., 37

${ }^{96}$ Boone, J.D. Better Trap-Neuter-Return..., cit.; Hamilton, F.E. Leading and Organizing Social Change..., cit.; and see Alley Cat Allies. How to Implement an Organizational Trap-Neuter-Return Program https:/www.alleycat.org/resources/how-to-implement-anorganizational-trap-neuter-return-program/ [Last consulted 13 May 2019] for detailed suggestions on marshalling data to make a case for TNR.

${ }^{97}$ Humane Society of the United States. Managing Community Cats..., cit., 15

${ }^{98}$ Schaffner, J.E. Community Cats..., cit., 76
} 
method's effectiveness ${ }^{99}$ or that are supportive of addressing the obstacles to TNR. ${ }^{100}$ At the very least, therefore, the question warrants further study in the future. It is not an indictment of TNR but rather an acknowledgment that human (mis)behavior is an important factor that must be studied and confronted as part of any feline population management program.

None of the above points calls into fundamental question the notion that TNR is the most humane and effective method currently available for addressing feral cat management. Rather, they are presented here as indications of some of the weaknesses that TNR advocates and practitioners must address in order to strengthen the practice.

\section{Section 3. The Swiss Case: General Background and Legal Landscape}

\subsection{Why the Swiss Case?}

There are several reasons to study Switzerland's experience with TNR. First, it is a country where the method has been carried out by non-profit groups in an organized manner for over two decades (and longer than that by individuals in their own capacity). And yet, outside of public materials produced by TNR practitioners and periodic coverage in the local press, surprisingly little seems to have been written about this case. It is hoped that an exploration of its strengths and continued challenges can ultimately add to existing efforts to strengthen TNR in Switzerland.

Second, given its wealth as a country, and animal welfare laws that are considered relatively progressive by global standards, one might assume Switzerland does not have a problem with feline overpopulation and the suffering of abandoned or feral cats. As section 4 seeks to show, however, this is a false assumption. A closer look at its experience, therefore, and how these problems are being dealt with, is warranted, and could contribute to broader conversations about animal welfare in Switzerland.

Third, as section 2 laid out, although TNR has been around for several decades in multiple countries, it continues to face many challenges, and practitioners and scholars are still learning what works best, how to improve the practice and how to respond to criticisms. The innovative or promising aspects of the Swiss case could prove useful to practitioners elsewhere in the world; further, the case reconfirms some of the lessons that TNR has turned up in other countries, thus corroborating the findings of other researchers. Adding case studies from places where the method has been carried out for years can only help the larger field of study around TNR. As one article on a US community's efforts to address companion animal overpopulation asserts, "multiple case studies make a strong case toward action."101

While this section and the next two do not constitute an in-depth study of TNR in Switzerland, they seek nonetheless to provide an overview of a well-established but understudied case for the reasons elaborated above. The analysis presented here is based primarily on an extensive review of publicly available materials (NGO reports and websites, press articles) and key informant interviews with TNR practitioners and NGO personnel from several organizations around the country. The concluding section of the article makes suggestions as to how this preliminary study might be expanded in the future to provide a fuller picture of the Swiss case.

\subsection{General Background on Switzerland}

Switzerland is a country of approximately 8.5 million people, ${ }^{102}$ with four official languages and 26 cantons, or member states. About two-thirds of the country is made up of "forests, lakes and mountains," and agriculture is an important sector of the economy, although it employs less than $10 \%$ of the population. ${ }^{103}$ There are three levels of political power in Switzerland: federal (the Confederation), cantonal, and communal

\footnotetext{
${ }^{99}$ Kreisler, R.E., Cornell, H.N., Levy, J.K. Decrease in Population..., cit. and Robertson, S. A. Review of Feral Cat Control..., cit. See also Levy, J.K., Crawford, P.C. Humane Strategies..., cit., 1358, who cite failed TNR programs in which "the presence of highly visible, well-fed cat colonies encouraged illegal abandonment of additional cats."

${ }^{100}$ Boone, J.D. Better Trap-Neuter-Return..., cit.

${ }^{101}$ Hamilton, F.E. Leading and Organizing Social Change..., cit., 289

${ }^{102}$ Swiss Confederation. Federal Statistical Office. Population. https://www.bfs.admin.ch/bfs/en/home/statistics/population.html [Last consulted 15 May 2019]

103 about.ch. Information about the Economy of Switzerland. Web page: https://www.about.ch/economy/index.html\#CH_Eco_Sectors [Last consulted 15 May 2019] In comparison, the sector employed just over $20 \%$ of the workforce in the early 1940 s. Fahrni, D. An Outline History of Switzerland: From the Origins to the Present Day (1994), 124
} 
(there are over 2,200 communes, or municipalities). ${ }^{104}$ Some cantons are primarily rural and sparsely populated, others are highly urbanized and heavily settled, still others are a combination of both countryside and urban centers. Cantons have their own constitutions as well as their own executive, legislative and judiciary institutions.

For their part, communes ("Gemeinde" in German) are "the basic unit of Swiss politics", which "enjoy the same sort of semi-sovereignty within the canton that the canton enjoys within the federation." 105 Communes can range from villages with under 100 people to large cities that have hundreds of thousands of residents. ${ }^{106}$

Swiss legislative authority rests with a bicameral parliament (the National Council, or the "lower house," and the Council of States, or "upper house"). Executive authority is held by the Federal Council, which consists of seven members who are elected by parliament. These seven Federal Councilors serve collectively as the head of state, and they each lead one federal department on a rotating basis (every year a president is elected from among the seven, but the role carries only representational powers.) A distinctive feature of the Swiss political system is its direct democracy, which gives citizens a certain amount of decisionmaking about how the country is run. For example, through the so-called "popular initiative", citizens can propose laws that can eventually be put to a national vote (they can also challenge newly passed laws through a similar process).

Human and animal health and well-being are overseen at the federal level by the Federal Food Safety and Veterinary Office (hereafter, FSVO). Each canton has a cantonal veterinary office, headed by the Cantonal Veterinary Officer. These offices ensure the enforcement of animal welfare-related regulations. ${ }^{107}$ Specific tasks of the Cantonal Veterinary Officers include, among other things, monitoring animal health and animal welfare in the cantons, supervising hygiene in slaughterhouses and issuing permits for animal testing. ${ }^{108}$

\subsection{In Brief: Cats - Owned, Stray and Feral}

According to the non-governmental animal welfare organization, Protection des Animaux Suisse (hereafter, PSA - see box below), over one-half of Swiss households have companion animals, ${ }^{109}$ and cats are the most popular companion animals in the country, with estimates ranging from 1.3 million ${ }^{110}$ to 1.7 million $^{111}$ cats owned as pets. One source reports that a third of all Swiss households have at least one cat, but only one-third of those cats are registered in the national companion animal database, ANIS. ${ }^{112}$ Switzerland does not require microchipping of cats; in contrast, it has required microchipping and registration of dogs since 2006. In an afterword to a practical guide to cat ownership published by the PSA in 2012, Dr. Dennis C. Turner, a renowned expert on domestic cats and behavioral researcher at the University of Zurich, wrote:

Our research shows that the vast majority of Swiss women and men have a positive attitude toward cats (and dogs) and are willing to devote enough time and money to their animals. There are, however, knowledge gaps, especially with regard to free-roaming cats and their problems. ${ }^{113}$

\footnotetext{
${ }^{104}$ Swiss Confederation. Swiss Political System - Facts and Figures.

https://www.eda.admin.ch/aboutswitzerland/en/home/politik/uebersicht/politisches-system-der-schweiz---fakten-und-zahlen.html [Last consulted 15 May 2019]

${ }^{105}$ Steinberg, J. Why Switzerland? (Cambridge University Press, second edition, 1996), 78

106 Swiss Confederation. Federal Statistical Office. Communes. https://www.bfs.admin.ch/bfs/en/home/statistics/regionalstatistics/regional-portraits-key-figures/communes/portraits-communes.html [Last consulted 15 May 2019]

107 Tierschutzgesetz (TSchG, Swiss Federal Animal Welfare Act, in effect since 1 September 2008), Art. 33 https://www.admin.ch/opc/de/classified-compilation/20022103/index.html

108 Swiss Federal Council. The Swiss Veterinary Service. https:/www.blv.admin.ch/blv/en/home/dasblv/organisation/veterinaerdienst-schweiz.html [Last consulted 21 June 2019]

${ }^{109}$ Protection Suisse des Animaux. Animaux de compagnie. http://www.protection-animaux.com/animaux_de_compagnie/index.html [Last consulted 17 May 2019]

${ }_{110}$ Protection Suisse des Animaux. Stériliser les chats au lieu de tuer. Feuille d'information (October 2015) http://www.chatsmisere.ch/images/downloads/mb_katzenkastration_fr.pdf [Last consulted 27 May 2019]

${ }^{111}$ Luna \& Filou campaign. Information flyer. Web page:

http://www.protection-animaux.com/publications/animaux_de_compagnie/infothek/chats_chiens/flyer_lunafilou_fr.pdf [Last consulted 17 May 2019]

${ }^{112} \mathrm{Ibid}$. See also http://www.protection-animaux.com/medias/pc2018/301018.html [Last consulted 17 May 2019]. ANIS is part of Identitas SA, a private company that collects and evaluates animal- and plant-related data. Identitas is majority-owned by the Swiss Confederation. See Swiss Confederation. Objectifs stratégiques assignés à Identitas SA par le Conseil fédéral pour les années 2019 à 2022. 1 June 2018 https://www.admin.ch/opc/fr/federal-gazette/2018/3947.pdf [Last consulted 11 June 2019]

113 Dr. Dennis C. Turner quoted in Protection Suisse des Animaux, Détention de chats conforme..., cit., 23 [Emphasis added. Translated from the French: "Nos travaux de recherche montrent que la grande majorité des Suissesses et des Suisses ont une attitude
} 


\section{Protection des Animaux Suisse (PSA)}

The PSA was founded in 1861 and is the oldest national animal protection organization in Switzerland. Its sections cover most of the Swiss cantons as well as Liechtenstein. Most of its funding comes from donor contributions; PSA "does not receive grants or subsidies from public authorities, although it assumes many tasks which, without [the PSA], would fall within the competence of the State." ${ }^{114}$ Each section of the PSA is independent of the national entity, has its own funding and decides on its own work projects. The sections pay a small amount in annual dues to the PSA, which subsidizes the organization's work on behalf of all of the sections (such as federal-level policy advocacy). ${ }^{115}$ Some of the regional sections are called "SPA" in French ("société pour la protection des animaux") - for example, SPA Valais or SPA La Côte - not to be confused with PSA, which refers only to the national entity. In German, the PSA is called STS, Schweizer Tierschutz.

Indeed, despite the popularity of cats as pets in Switzerland, the country has a notable problem with both the proliferation of feral and abandoned cats and how they are treated. The Swiss animal welfare organization, Network for Animal Protection (hereafter, NetAP), estimates that there are between 100,000 and 300,000 ownerless or abandoned cats in the country. ${ }^{116}$ It is not clear what the relative breakdown is, within this figure, of feral cats (that is, non-socialized cats, or cats that have never lived with humans), cats who were lost by their owners, and abandoned cats, though the PSA does publish annual cantonal figures, collected by its sections, of abandoned, confiscated and found cats. ${ }^{117}$ According to one cantonal veterinary officer, there is no census of cats in Switzerland. ${ }^{118}$

The latest figures published by the PSA reveal that, of the 18,385 animals (cats, dogs, rodents and rabbits, reptiles and other species) taken in by its 67 sections in 2017, almost $60 \%$ were cats, a proportion that, the PSA notes, remains very high. ${ }^{119}$ For its part, NetAP claims that "an estimated 100,000 unwanted cats are killed each year in Switzerland, that is, killed, drowned, suffocated, slaughtered or euthanized," 120 a shocking figure given the country's reputation as a trailblazer in animal welfare.

Before moving to a discussion of TNR in Switzerland and how its proponents are using it as one way to address this problem, the next sub-section will take a broader look at the legal framework in Switzerland for animal welfare in general, as well as for feral and stray or ownerless cats in particular.

\subsection{Swiss Law in Relation to Animal Welfare}

Switzerland is often held up as a model on animal welfare law, and indeed, animals have gained certain protections in Swiss law in recent decades. But in the estimation of a number of legal scholars, the progress is not always clear-cut, and much work remains to be done. As Michel and Schneider Kayasseh point out, for example, "the situation of animals in Swiss law is at one and the same time a matter of progress and regress." 121

positive envers les chats (et les chiens) et sont prêtes à consacrer suffisamment de temps et d'argent à leurs animaux. Il y a pourtant des lacunes de connaissances surtout en ce qui concerne les chats vivant en liberté et leurs problèmes."]

${ }^{114}$ Protection Suisse des Animaux. À propos de nous. http://www.protection-animaux.com/psa/index.html [Last consulted 28 June 2019] [Translated from the French: "ne touche pas de subvention ni de subside des pouvoirs publics, bien qu'elle assume de nombreuses tâches qui, sans elle, relèveraient de la compétence de l'Etat."']

${ }^{115}$ Interview with Stéphane Crausaz, Responsable de la Communication, Société vaudoise pour la protection des animaux. 12 March 2019.

${ }^{116}$ Network for Animal Protection. Kastrationspflicht - Schweiz https://www.netap.ch/de/aktivitaeten/recht-undpolitik/kastrationspflicht-schweiz [Last consulted 17 May 2019] The document specifically uses the word "herrenlosen," or "ownerless". The PSA puts the figure at approximately 300,000. Protection Suisse des Animaux. Chiffres et faits. Statistique protection des animaux 2017/Rapport "contrôles protection des animaux." Communiqué de press 30 octobre 2018 http://www.protectionanimaux.com/medias/pc2018/301018.html [Last consulted 17 May 2019]

117 For the latest figures (2017) provided on PSA's website, see Protection Suisse des Animaux. Statistique protection des animaux/Côntroles protection des animaux $(30 \quad$ October 2018) http://www.protectionanimaux.com/medias/statistique2017/index.html [Last consulted 17 May 2019]

${ }_{118}$ Pierre-François Gobat, cantonal veterinarian of Neuchatel, cited in Bourquin, A. Chat ne peut plus durer! Protection des Animaux Suisse (9 August 2017). Web page: http://www.chats-misere.ch/images/downloads/in-den-medien-fr/2017-09-08_a_la_chaux-defonds.pdf [Last consulted 17 May 2019]

${ }_{119}$ Protection Suisse des Animaux. Chiffres et faits..., cit.

${ }^{120}$ Network for Animal Protection and Tier im Recht. Petition, Kastrationspflicht für Freigänger-Katzen in der Schweiz (June 2018) https://www.kastrationspflicht.ch/de/kampagne [Translated from the French: "il est estimé que 100.000 chats indésirables sont tués, chaque année, c'est-à-dire battus à mort, noyés, étouffés, abattus ou euthanasiés."]

${ }^{121}$ Michel, M. and Schneider Kayasseh, E. The Legal Situation of Animals in Switzerland: Two Steps Forward, One Step Back - 
Gerritsen asserts that while Swiss animal welfare legislation is "progressive" by global standards, principles of fundamental respect for animal welfare "are restricted to a minimum and at times even ignored." 122 For his part, Bolliger concludes that, due to weaknesses in animal welfare protection in Switzerland, "the far-reaching conceptual reorganization of Swiss national law has not yet led to a fundamental change in the human-animal relationship in practice." 123

What follows is a brief summary of the main animal welfare provisions in Swiss law, as well as certain laws and regulations pertaining to cats, including stray and feral cats. The focus here is mainly on federal, not cantonal, laws. The sub-section also discusses key criticisms made by several legal experts who have analyzed Swiss law as it relates to animal welfare. Some of these criticisms will be revisited later in the article, in relation specifically to TNR in Switzerland.

In 1992, the Swiss Federal Constitution was amended by a provision protecting "the dignity of living beings"124 ("Würde der Kreatur"). The relevant provisions, in Article 120 of Constitution, read:

1. Human beings and their environment shall be protected against the misuse of gene technology.

2. The Confederation shall legislate on the use of reproductive and genetic material from animals, plants and other organisms. In doing so, it shall take account of the dignity of living beings as well as the safety of human beings, animals and the environment, and shall protect the genetic diversity of animal and plant species. ${ }^{125}$

This development was significant because, although the Constitution deals with dignity only in relation to animal reproductive and gene technology, as Bolliger notes, "the protection of animal dignity is recognized as a general constitutional principle in Switzerland." ${ }^{26}$ It was the first time a national constitution "introduced and guaranteed" non-human dignity, ${ }^{127}$ and in his words, the concept of animal dignity "represents a biocentric expansion of Swiss law granting animals a moral value, irrespective of their sentience." 128 Giménez-Candela designates Switzerland "the absolute precursor and pioneering country" on animal protection, not only for its constitutional treatment of animal dignity but also for having been the first country in the world, in 1893, to prohibit the slaughter of animals without stunning. ${ }^{129}$

A discussion of the nuances of non-human versus human dignity in Swiss law is beyond the scope of this article. ${ }^{130}$ It is worth noting here, however, Bolliger's assertion that the Swiss constitution's protection of non-human dignity "must signify, for example, that highly cruel treatments (such as brutal catching or killing methods)....are unconstitutional." 131 This is one potential contact point between the constitutional concept of animal dignity and the question of how community cats are treated in Switzerland. As Michel and Schneider Kayasseh write, although "no single and uniform understanding of the context of the constitutional concept of the dignity of the Creature has as of yet crystallized" in Switzerland, "prevailing legal opinion is that protection of the dignity of the Creature necessitates respect for the inherent value of animals." ${ }^{132}$ It is important to underscore that while human dignity is absolute in Swiss law, animal dignity is not; in certain circumstances, violations of animal dignity can be "legally justified by prevailing human interests," 133 a point that has come in for criticism by animal law jurists. ${ }^{134}$ Interestingly, Bolliger points out that the "neutering of pets and stray animals" could fall into the category of "underlying values and interests that are deemed legitimate in Switzerland" and could "thus override the protection of animal dignity." ${ }^{135}$ This is another

\footnotetext{
Many Steps to Go, in Journal of Animal Law VII (2011), 41

122 Gerritsen, V. Animal Welfare in Switzerland - Constitutional Aim, Social Commitment, and a Major Challenge, in Global Journal of Animal Law GJAL 1 (January 2013), 8

${ }^{123}$ Bolliger, G. Legal Protection of Animal Dignity in Switzerland: Status quo and Future Perspectives, in Animal Law 22 (2016), 312

${ }^{124}$ Bolliger, G. Legal Protection of Animal Dignity..., cit., 323

${ }^{125}$ Bundesverfassung der Schweizerischen Eidgenossenschaft (BV, Federal Constitution of the Swiss Confederation), Arts. 120(1) and 120(2) https://www.admin.ch/opc/de/classified-compilation/19995395/index.html [translation from the unofficial English version provided on the Swiss federal government website https:/www.admin.ch/opc/en/classified-compilation/19995395/index.html\#a33 ]

${ }^{126}$ Bolliger, G. Legal Protection of Animal Dignity..., cit. 328

${ }^{127}$ Ibid., 324 and 355-56

128 Ibid., 311

129 Giménez-Candela, T. Dignity, Sentience, Personality: The Legal Relationship between Animals and Humans, in dA.Derecho Animal 9:2 (2018)

${ }^{130}$ See Michel, M., Schneider Kayasseh, E. The Legal Situation..., cit., section II A, and Bolliger, G. Legal Protection of Animal Dignity..., especially sections IV and V.A., for thoughtful discussions of this point.

${ }^{131}$ Bolliger, G. Legal Protection of Animal Dignity..., cit. 333

${ }_{132}$ Michel, M. and Schneider Kayasseh, E. The Legal Situation..., cit., 9

${ }^{133}$ Bolliger, G. Legal Protection of Animal Dignity..., cit., 312

${ }^{134}$ Ibid., 344; see section V.C. of Ibid. for a critical discussion of these justifications.

${ }^{135}$ Ibid., 350
} 
potential link between animal dignity and the question of the management of cat colonies, and will be taken up again in section 4 .

A further important development was the addition, in 2003, of a provision to the Swiss Civil Code to the effect that "animals are not things" ("Tiere sind keine Sachen"). ${ }^{136}$ Michel and Schneider Kayasseh assert that this provision "delivers an important message: Swiss law recognizes that animals are sentient beings and not just another object like a car or a chair." 137 They concede, on the other hand, that animals still do not have a "concrete legal status" under Swiss law, and "have neither gained legal personhood nor do they have human caregivers or guardians instead of owners." 138 In their view, "the law states that they are no longer objects; but in most cases they are still treated as such." 139

The national Animal Welfare Act (hereafter, AWA) and the national Animal Welfare Ordinance (hereafter, AWO) are the two key pieces of Swiss legislation on animal welfare. The AWA and the AWO, first promulgated in 1981, were revised in 2005 and came into force in 2008. ${ }^{140}$ As its first article states, the AWA's purpose "is to protect the dignity and welfare of animals." 141 The AWA and the AWO together "form[] the core of Swiss animal welfare law," though animal welfare provisions also appear in other federal statutes such as the Civil and Criminal Codes. ${ }^{142}$ Cantons have their own regulations to implement federal animal welfare law. As Bolliger notes, however, "Swiss animal welfare law is exclusively regulated by national legislation. The cantons are responsible for enforcing animal welfare laws but are prohibited from issuing differing or additional substantive provisions regarding animal protection." 143

Two important provisions of the AWA are Article 4, para. 2, which prohibits inflicting pain or suffering on an animal "without justification", ${ }^{144}$ and Article 26, which prohibits mistreatment of animals, including deliberately killing an animal in a way that causes suffering, and abandoning an animal "with the intention of disposing of it", ${ }^{145}$ with violators subject to imprisonment or a fine. ${ }^{146}$ Article 6(1) of the AWA requires that "anyone who keeps or looks after animals must feed and care for them properly and provide them with the activities and freedom of movement needed for their well-being, as well as shelter where necessary." 147 Animals that have been neglected can be confiscated by the authorities. ${ }^{148}$ In Switzerland, animal cruelty of every kind "qualifies as a misdemeanor - there is no animal welfare crime in the rank of felony under Swiss law." 149

In the Animal Welfare Ordinance, the general provisions of the AWA are made much more specific and detailed. Where, for example, article 26 of the AWA contains only a general prohibition on the mistreatment of animals, the AWO sets out prohibited acts in relation to several individual species (cattle, pigs, sheep and goats, domestic poultry, horses, dogs, fish and decapods). ${ }^{150}$ Article 24 of the AWO, on "other prohibited actions", mentions cats in particular, and forbids "amputation of the claws of domestic cats and

\footnotetext{
136 Schweizerisches Zivilgesetzbuch (ZGB, Swiss Civil Code, in effect since 10 December 1907), Art. 641a https://www.admin.ch/opc/de/classified-compilation/19070042/index.html. As Bolliger notes, before Switzerland, only Austria and Germany had enacted similar laws, in 1988 and 1990 respectively, stating that animals were not merely things (Bolliger, G. Legal Protection of Animal Dignity..., cit., n. 356). On the movement toward the "de-objectification" of animals in the laws of European and other countries, and Switzerland's place in that movement, see Giménez-Candela, T. The De-Objectification of Animals in the Spanish Civil Code, in dA.Derecho Animal 9:3 (2018).

${ }^{137}$ Michel, M. and Schneider Kayasseh, E. The Legal Situation..., cit., 20

${ }^{138}$ Ibid.

${ }^{139}$ Ibid.

${ }^{140}$ In German, the Animal Welfare Act is called the Tierschutzgesetz (TSchG) and in French, the Loi fédérale sur la protection des animaux (LPA). In German, the Animal Welfare Ordinance is the Tierschutzverordnung (TSchV) and in French, Ordonnance sur la protection des animaux (OPAn)

${ }^{141}$ TSchG, Art. 1 [Zweck dieses Gesetzes ist es, die Würde und das Wohlergehen des Tieres zu schützen.] Unless otherwise indicated below, the English translations of text from the TSchG are from the unofficial English version provided here: https://www.zuerchertierschutz.ch/fileadmin/user_upload/Tierschutzthemen/pdf/Tierschutzgesetz_e.pdf. Note that animal dignity was included only in the 2008 revision of the AWA, not in its earlier version (Bolliger, G. Legal Protection of Animal Dignity..., cit., n. 148).

${ }^{142}$ Bolliger, G. Legal Protection of Animal Dignity..., cit., 320 and 321-22

${ }^{143}$ Ibid., n.56, citing Bolliger, G., Goetschel, A., Richner, M., Spring, A. Tier im Recht Transparent 13 (2008).

144 TSchG, Art. 4 para. 2 [ungerechtfertigt]

${ }^{145}$ Ibid., Art. 26 paragraphs 1a, $1 \mathrm{~b}$ and $1 \mathrm{e}$ [sich seiner zu entledigen]

${ }^{146}$ Ibid., Art. 26 paras. 1 and 2

147 TSchG, Art. 6, para. 1 [Wer Tiere hält oder betreut, muss sie angemessen nähren, pflegen, ihnen die für ihr Wohlergehen notwendige Beschäftigung und Bewegungsfreiheit sowie soweit nötig Unterkunft gewähren]

${ }^{148}$ Ibid., Art. 24 para. 1

${ }^{149}$ Bolliger, G. Legal Protection of Animal Dignity..., cit., 364

150 Tierschutzverordnung (TSchV, Swiss Federal Animal Welfare Ordinance, in effect since 1 September 2008), Arts. 17-23 https://www.admin.ch/opc/de/classified-compilation/20080796/index.html
} 
other felids (Felidae)."151 The AWO's Section 11, Article 80, deals with domestic cats. Interestingly, the first paragraph of this article requires that "cats kept on their own shall have daily contact with humans or visual contact with members of their own species." 152

\subsubsection{Select Criticisms of Swiss Animal Welfare Law}

Several legal experts have produced detailed critical analyses of Swiss animal welfare law. This subsection will explore only a few aspects of these criticisms, ${ }^{153}$ in particular those that are most relevant to TNR. The first major criticism to consider is lack of protection of the life of animals. A number of scholars have noted that Swiss law protects animals' dignity and prohibits their inhumane death, but it does not actually protect the life of animals. For example, Michel and Schneider Kayasseh write:

In contrast to the animal-protection laws in the German-speaking world (Germany and Austria) and to some degree in contrast to protection of the dignity of the Creature, in the Swiss Animal Protection Act there is regrettably no protection for the life of the animal. This means that the killing of an animal is still fundamentally allowed so long as it remains within the parameters of the Animal Protection Act. ${ }^{154}$

In this vein, Bolliger points out that it is legal in Switzerland to euthanize a healthy animal, even if, "from an ethical and animal welfare point of view," euthanasia "without good reason should clearly be rejected." 155 This is relevant to TNR as, for example, the law could allow for the trapping and killing of healthy feral cats as long as there is no suffering. ${ }^{156}$ What is more, proving that an animal did not suffer while being killed presents considerable difficulties. ${ }^{157}$

Secondly, sanctions of animal mistreatment are light. According to Article 26 of the AWA, animal cruelty or neglect, including abandonment of an animal, can be criminally sanctioned by a prison term of up to three years, or a fine. But the cantons, which are responsible for ensuring enforcement of the AWA, ${ }^{158}$ prosecute violations of this law unevenly (see below), and where there are convictions at all, "as a rule people are let off with a fine of some several hundred Swiss francs." 159 Gerritsen reports that imprisonment solely for animal crimes is very rare. ${ }^{160}$

Related to this, then, is a third major criticism: that animal welfare law enforcement is uneven, varying considerably from one canton to another. Gerritsen asserts that this is due to a "deeply anchored federalism" in Switzerland, which means that the way cantons enforce laws "strongly depends on the respective cantonal government's attitude." ${ }^{61}$ Thus, "[c]onspicuously small cantons without urban areas show more difficulties

${ }^{151}$ TSchV, Art. 24(a) [das Amputieren der Krallen von Hauskatzen und anderen Katzenartigen (Felidae)]. Unless otherwise indicated below, the English translations of text from the TSchV are from the unofficial English version provided here https://www.blv.admin.ch/dam/blv/en/dokumente/tiere/rechts-und-vollzugsgrundlagen/animal-welfare-ordinance-

tschv.pdf.download.pdf/Animal_Welfare_Ordinance_(TSchV)_position_as_at_1.4.2011.pdf

152 TSchV., Art. 80, para. 1 [Einzeln gehaltene Katzen müssen täglich Umgang mit Menschen oder Sichtkontakt mit Artgenossen haben]

${ }^{153}$ Bolliger discusses major weaknesses of Swiss animal welfare law, such as its failure to cover animals other than vertebrates, cephalopods and decapods, and its failure to prohibit instrumentalization of animals through, e.g. animal research and factory farming (Bolliger, G. Legal Protection of Animal Dignity..., cit., section V.F.) These and other criticisms are beyond the scope of this article. ${ }_{154}$ Michel, M., Schneider Kayasseh, E. The Legal Situation..., cit., 15. They are referring to the TSchG.

${ }^{155}$ Bolliger, G. Legal Protection of Animal Dignity..., cit., 358; see Ibid., n. 444 for references to other scholars who criticize Swiss law for its lack of protection of animals' lives. Bolliger also points out (n. 344) that Swiss animal welfare law "sets strict general standards regarding the (lawful) killing of vertebrates, cephalopods and decapods." For more on why Swiss animal welfare law does not protect animals' lives per se, see Ibid., 357. It is worth noting that the code of ethics of the Society of Swiss Veterinarians prohibits the killing of healthy animals. NetAP cites this point in a discussion of the killing of feral cats in Switzerland. See Network for Animal Protection. Hochrechnung Katzentötungen Schweiz: Mindestens 100'000 Katzen warden pro Jahr in der Schweiz getötet! (10 September 2014) https://www.netap.ch/images/Downloads/100000-Katzentoetungen_Zahlen_201400910-Berechnumg-NetAP.pdf

${ }_{156}$ TSchG, Art. 26, para. 1(b) says: "Anyone who willfully...deliberately and without provocation kills an animal in a manner that causes it suffering" is liable to a fine or imprisonment [wer vorsätzlich... Tiere auf qualvolle Art oder aus Mutwillen tötet]

157 This point was made in a press article about a cat found bludgeoned to death on a Swiss farm in 2017. The animal welfare group that found the cat suspected the farmer in the cat's killing, but Vanessa Gerritsen of TIR, quoted in the article, points out that for there to be a conviction for willingly inflicting pain, there must be proof of the animal's suffering, which is very difficult to establish. 20min.ch. Bauern sollen keine Katzen töten dürfen. 12 September 2017 https://www.20min.ch/schweiz/news/story/Bauern-sollenkeine-Katzen-toeten-duerfen-21478946 [Last consulted 28 May 2019]

${ }^{158} \mathrm{TSchG}$, Art. 32, para. 2 and Art. 33

${ }^{159}$ Michel, M., Schneider Kayasseh, E. The Legal Situation..., cit., 16-17 (one Swiss franc is roughly equivalent to one US dollar). As the authors note, the animal law organization Stiftung für das Tier im Recht has demonstrated this laxity in its annual analysis of Swiss law enforcement of animal welfare provisions (Ibid., 16).

${ }^{160}$ Gerritsen, V. Animal Welfare in Switzerland..., cit., 3, n.9. See also Bolliger, G. Legal Protection of Animal Dignity..., cit., n. 504

${ }^{161}$ Gerritsen, V. Animal Welfare in Switzerland..., cit., 11 
with providing enough personnel seriously to fulfil federal standards, although there are some positive exceptions." 162 As a result, some cantons report few or no violations of animal welfare law in a year, "which is simply unrealistic." 163 The independent Swiss not-for-profit organization, Stiftung für das Tier im Recht (hereafter, TIR), promotes the development of law and ethics for the protection of animals. TIR analyzes these discrepancies on an ongoing basis, and has attributed poor enforcement by certain cantons to their "disinterest and indifference", concluding that violations of animal welfare laws "are still understood as trifles in many places." "164 For his part, Bolliger, who is the executive director of TIR, argues that there is an "urgent need for better education of Swiss law enforcement agencies regarding animal welfare law in general." 165 The lack of a consistent approach to animal welfare by local authorities is a point that emerged in numerous interviews with key figures working in TNR in Switzerland, and will be revisited in sections 4 and 5 .

Fourthly, certain laws and regulations regarding animal welfare are marked by vague wording, which can lead to lack of, or difficulty in, enforcement. A case in point is Article 25(4) of the AWO, which provides that an animal owner "shall take reasonable precautions to prevent the animals from excessively reproducing." 166 TNR proponents have pointed to this clause as problematic, because in not specifying the concept of "excessive" reproduction, the provision is also not consistently enforced. ${ }^{167}$ In their view, a major contributing factor to the proliferation of feral and unowned cats in Switzerland, and thus to the suffering of these animals, is the fact that cat owners allow their intact pets to roam and breed with feral cats, despite the existence of this provision in the AWO. They assert that, in order to address this problem, the regulation must be made clearer and more enforceable. To this end, TIR and NetAP, with support from other animal welfare non-governmental organizations (NGOs), have filed a petition on mandatory castration of outdoor - that is, owned, free-roaming - cats with the federal government (to be discussed in depth in section 4). On the petition website, the NGOs state, with reference to AWO Art. 25(4): "This order is obviously not enough, it must be made concrete for free-roaming cats." 168

\subsubsection{Relevant Swiss Laws in Relation to Cats}

Research turned up few references in federal law specifically regarding stray or feral cats or colonies of unowned cats. According to the Swiss Civil Code, anyone who finds a lost animal must inform the owner or, if the owner is unknown, the competent authority (to be designated by the cantons); in the latter case, once two months have elapsed from the date of informing the authorities, the finder of the animal becomes the owner. ${ }^{169}$ The Civil Code also notes that "Domesticated animals become ownerless once they regress to a feral state and no longer return to their masters." 170

In October 2018, the FSVO published a document entitled "Questions and responses on castration of free-roaming cats and on electronic microchips." The document, coming three months after the abovementioned petition, restates the AWA's general prohibitions against mistreatment and abandonment of animals. It also recalls the AWO's provision against excessive breeding, and warns of the need to castrate kittens early due to cats' tendency to reproduce rapidly. And it notes that Austria requires castration of freeroaming (owned) cats and that most German states ("Länder") have authorized their cities and towns to require

162 Ibid.

${ }^{163}$ Ibid.

164 Ibid., 12. TIR maintains a database of all animal welfare criminal cases in Switzerland, available at: https://www.tierimrecht.org/de/tierschutzstraffalle/ [Last consulted 24 June 2019]. Its analyses of Swiss animal protection practice are available on its website at https:/www.tierimrecht.org/de/tir/publikationen/gutachten-berichte/

${ }^{165}$ Bolliger, G. Legal Protection of Animal Dignity..., cit., 392

$166 \mathrm{TSchV}$, Art. 25, para. 4 [Die Tierhalterin oder der Tierhalter muss die zumutbaren Massnahmen treffen, um zu verhindern, dass sich die Tiere übermässig vermehren]

${ }^{167}$ Bianca Körner, Lawyer, Stiftung für das Tier im Recht, telephone interview with author, 20 March 2019 and written communication to the author, 3 July 2019. See also Stiftung für das Tier im Recht and Network for Animal Protection. Stellungnahme zum Entscheid des Ständerats zur Ablehnung der Petition von „SOS Chats“ zur Einführung einer obligatorischen Kastrationspflicht für Katzen (16 December

https://www.netap.ch/images/Projekte/Kastrationen/Schweiz/NetAP_Stellungnahme_Ablehnung_Petition_SOS_Chats_20161216_F inal.pdf [Last consulted 3 July 2019]

168 Network for Animal Protection, Stiftung für das Tier im Recht. Pétition: Obligation de Castration des Chats libres de leurs Déplacements. Questions et Réponses https://www.kastrationspflicht.ch/fr/faq [Last consulted 15 May 2019] [Translated from the French: "Cette consigne n'étant manifestement pas suffisante, elle doit se concrétiser pour les chats libres de leurs déplacements".

169 ZGB, Art. 720a and Art. 722 (1 bis)

${ }^{170}$ ZGB, Art. 719 para. 2 [Gezähmte Tiere werden herrenlos, sobald sie wieder in den Zustand der Wildheit geraten und nicht mehr $\mathrm{zu}$ ihrem Herrn zurückkehren; translation taken from the unofficial English version provided here: https://www.admin.ch/opc/en/classified-compilation/19070042/201801010000/210.pdf] 
the same. ${ }^{171}$ The FSVO takes the position, however, that existing directives and criminal provisions in Switzerland are sufficient to prevent uncontrolled feline breeding, and it therefore rejects the petitioners' argument that the law must be tightened or modified. ${ }^{172}$

To the question of who is responsible for castrating "colonies of stray cats" ("des colonies de chats errants"), the FSVO states:

In principle, it is the keeper of animals who is responsible for their castration. It is therefore necessary to determine on a case by case basis to whom the cats belong. Every person who finds a stray cat should inform the competent cantonal office. If the owner does not appear, the person who found the cat becomes the owner at the end of two months (cf. art. $722 \mathrm{CC}$ ) and thus assumes the responsibility for its castration. If the person does not wish to take ownership of the animal, $\mathrm{s} / \mathrm{he}$ should entrust it to a shelter, which then becomes the keeper and must take care of the castration. ${ }^{173}$

This statement does not take account specifically of cat colony caregivers, who would neither take ownership of community cats nor turn them over to a shelter. The FSVO's arguments, and animal welfare organizations' rebuttal of its positions, will be taken up again in section 4, in a discussion of the abovementioned petition.

According to Isabelle Schnell, a lawyer with TIR, "there is no legal provision according to which the [local] community, i.e. the state, would be responsible" for unowned animals, though she points out that this would be "welcome from an animal welfare perspective." 174 Section 4 will discuss two examples of cantonal or commune-level accords signed with TNR providers that seem promising in terms of local authorities' facilitating castration campaigns. The apparent absence of specific ordinances in Switzerland dealing with cat colonies or feral cat populations contrasts with the US case; as mentioned in section 2, hundreds of local governments in the U.S. have enacted ordinances on TNR. And as will be discussed in section 5, feral cat advocates in various countries have found both obstacles in these ordinances and opportunities to work with lawmakers to create or modify local laws so as to facilitate TNR.

The Swiss case seems to stand apart from other countries where municipalities have embraced TNR and worked with practitioners to reform or create ordinances that support these operations. In this narrow sense, at least, Switzerland's experience might echo that of the UK, about which Dufau has written, "there is a notable shortage of legal references regarding cats compared to dogs. The municipalities do not have jurisdiction over stray cats...for the cats, it is the [animal] protection organizations that take on the task of managing the colonies." ${ }^{175}$ Similarly, in Switzerland it has been animal welfare organizations, aided in crucial measure by volunteers, who have taken it on themselves to address feline overpopulation. To the extent that the research found examples of municipalities taking on a role in managing community cat populations, these were very narrow roles, and instances in which they were approached to support extant TNR initiatives carried out by animal welfare organizations.

In a related vein, one other legal provision worth noting is Article 5 of the Swiss federal hunting law, which allows feral cats to be hunted throughout the year. ${ }^{176}$ As pointed out by NetAP and TIR, the two groups that launched the mandatory castration petition, each canton's hunting law "determines if and under what conditions the cats can be killed." ${ }^{177}$ Pointing to existing provisions in the form of both the hunting law and

\footnotetext{
${ }^{171}$ Swiss Federal Food Safety and Veterinary Office. Questions et réponses sur la castration des chats libres de leurs déplacements et

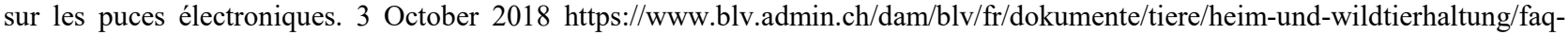
katzen-kastration-mikrochips.pdf.download.pdf/Katzen-Kastrieren_-_Fragen_und_Antworten_FR.pdf [Last consulted 21 June 2019] 172 Ibid.

${ }^{173}$ Ibid. [translated from the French: "En principe, c'st le détenteur des animaux qui est responsible de leur castration. Il faut donc déterminer au cas par cas à qui appartiennent les chats. Toute personne qui recueille un chat égaré doit le signaler à l'office cantonal compétent. Si le propriétaire ne se manifeste pas, la personne qui a trouvé le chat en devient propriétaire au bout de deux mois (cf. art. $722 \mathrm{CC}$ ) et assume par conséquent la responsabilité de sa castration. Si la personne ne souhaite pas avoir la propriété de l'animal, elle doit le confier à un refuge, qui en devient alors le détenteur et doit se charger de la castration.”]

${ }^{174}$ Written communication from Isabelle Schnell, Lawyer, Stiftung für das Tier im Recht, 19 June 2019 [translated from the French: "il n'existe aucune disposition légale selon laquelle la communauté, c'est-à-dire l'Etat, serait responsable des animaux sans maître. Un tel règlement serait toutefois le bienvenu du point de vue du bien-être animal."']

175 Dufau, A. Estatuto jurídico del gato callejero..., cit., 97 [translated from the Spanish: "es notable la escasez de referencias jurídicas relativa a los gatos en comparación con los perros. Los municipios no tienen competencia sobre los gatos callejeros...para los gatos, son las organizaciones proteccionistas las que toman el cometido de la gestión de las colonias.”]

${ }^{176}$ Art 5, para. 3(a), Gesetz uber die Jagd und den Schutz wildlebender Säugetiere und Vögel (JSG) (in effect since 1 April 1988) https://www.admin.ch/opc/de/classified-compilation/19860156/index.html

${ }^{177}$ Network for Animal Protection, Stiftung für das Tier im Recht. Pétition...Questions et Réponses..., cit. [translated from the French: "si et dans quelles conditions les chats peuvent être abattus."] It is noteworthy that the canton of Geneva has prohibited hunting since 1974. Global Animal Law project. Database legislation. Animal laws at national level - Switzerland.
} 
the AWO Art. 25(4) on the prevention of excessive breeding, the petitioners argue that there is a lack of regulation of the feline population in Switzerland: "Thus, animal protection legislation provides for control of the feline population but does not indicate effective implementation. In the end, the feline population is not regulated." 178

Interestingly, the NGO World Animal Protection gives Switzerland an overall grade of "A," the highest possible ranking on a scale of $\mathrm{A}$ to $\mathrm{G}$, for its protection of animals, and in particular, the group writes that "the legal provisions relating to companion animals are detailed and wide-reaching in their scope." 179 It continues: "However, the law does not currently contain provisions on humane companion animal population control" and "there appear to be resource and socio-cultural barriers to introducing humane population control methods for cats." ${ }^{180}$ It reports, further, that a 2013 petition to ban the hunting of feral cats was rejected in Parliament, and that Doris Leuthard, then the Head of the Federal Department of Environment, Transport, Energy and Communications, argued that the proposed ban would be too expensive and difficult to implement (through trapping and sterilization), and would impinge on the sovereignty of the cantons. ${ }^{181}$ Leuthard also argued that stray cats were not a major problem in Switzerland, ${ }^{182}$ a position clearly at odds with the abovementioned argument by the petitioners that it is a problem and it is not regulated. World Animal Protection underscores the aspect of cantonal sovereignty as a potential "structural barrier" to improving animal welfare. ${ }^{183}$ The barriers to humane population control measures for cats in particular will be revisited in section 5 .

\section{Section 4. TNR in Switzerland}

"The sight of feral cats is heartbreaking...Those who think that this exists only in the global south are mistaken. In Switzerland, too, one of the richest countries in the world, the number of stray cats is estimated at more than 100,000 “.”"184

\section{"Castration means fighting the causes, not the symptoms!" 185}

The research for this article found no analytical or scientific articles on TNR in Switzerland. That factor shaped the current section in two ways. First, what follows is not a quantitative account of the results of TNR operations in the country; rather, it is a qualitative discussion of these operations. Second, the narrative for this section had to be pieced together from public materials of NGOs, press coverage and key informant interviews. It begins by laying out the landscape of TNR in Switzerland: when it emerged, how it is carried out and by whom. Due to research limitations, the picture provided is not based on a comprehensive canvassing of TNR in a representative sampling of cantons; as an overview, therefore, it will necessarily contain certain generalizations. The second part of the section explores some of the strengths, or promising aspects, of TNR as it is practiced in Switzerland, based primarily on the interviews. That discussion will lead into the final section, which delves into certain important challenges to TNR in Switzerland, bringing in lessons from elsewhere in the world that might be helpful in addressing these.

\subsection{The Landscape}

\footnotetext{
https://www.globalanimallaw.org/database/national/switzerland/ [Last consulted 30 April 2019]

${ }_{178}$ Network for Animal Protection, Stiftung für das Tier im Recht. Pétition: Obligation de Castration des Chats libres de leurs Déplacements. https://www.kastrationspflicht.ch/fr/campagne [Last consulted 1 May 2019] [translated from the French: "Ainsi, la législation sur la protection des animaux prévoit un contrôle de la population féline mais elle n'indique pas de mise en oeuvre efficace. Au bout du compte, la population féline n'est pas régulée."]

179 World Animal Protection. Animal Protection Index: Swiss Confederation Country Report (2014), 7 https://api.worldanimalprotection.org/country/switzerland [Last consulted 2 May 2019] These are the most recent rankings. In certain sub-categories, the group gives Switzerland a rank of "B" or "C".

${ }^{180} \mathrm{Ibid}$, emphasis added

${ }^{181}$ Ibid. The report also notes (p. 7) that "The hunting of cats is reported to facilitate an underground market in illegal cat fur, which is another welfare concern that the government is attempting to address with stricter penalties."

182 Ibid., 8

${ }^{183}$ Ibid, 13 and 15

${ }^{184}$ Zech, M. Une petite intervention empêche de grandes souffrances. L'Ami des Animaux, 3/15 (24 September 2015.) [Translated from the French: "La vue des chats harets est navrante...Ceux qui pensent que cela n'existe que dans les pays du sud se trompent. En Suisse aussi, l'un des pays les plus riches du monde, le nombre de chats errants est estimé à plus de 100,000.”]

${ }^{185}$ Network for Animal Protection. Verwilderte Katzen - was tun? Wegweiser Nr. 3, 2016 [Translated from the German: "Kastrationen bedeuten Ursachen - statt Symptombekämpfung!']
} 
Given the paucity of literature on TNR in Switzerland, it is difficult to say with certainty how long it has been carried out. Interviews with key informants revealed that individuals have been undertaking TNR on their own, without organizational support, for decades, in some cases since the 1970s and 80s. Over the past 20 to 25 years, what has evolved is a system in which TNR is conducted almost (if not) entirely by private, not-for-profit entities and private citizens all over the country, with the PSA and its sections playing an important role along with many other animal welfare NGOs, as well as an unknown number of individual volunteers.

Turning first to the PSA's role: formal organizational backing for TNR seems to have started in 1996, when the PSA began providing annual financial contributions to its sections in Switzerland (and Liechtenstein) to undertake campaigns to spay and neuter unowned and feral cats, including those living near farms, in particular. ${ }^{186}$ The PSA now contributes between 300,000 and 400,000 Swiss francs (CHF) per year to its sections, some of which are also animal shelters; by the PSA's estimates, the sections themselves provide about the same amount, in their own funds, toward these efforts. ${ }^{187}$ The organization reports that these castration campaigns, which do not receive public sector funding, have resulted in the trapping, neutering, veterinary treatment and releasing of over 180,000 cats in total since the PSA began to support the operations. ${ }^{188}$

Interviews with a number of PSA sections turned up different methods through which they carry out TNR. In some instances, the section completely "outsources" the work, lending traps to individuals who capture the cats, bring them for neutering to a veterinarian with whom the section has a partnership, and collect the cats afterward for release (ideally) to where they were found. In other cases, the section's own staff or trained volunteers may carry out the trapping and returning of the cats after they are neutered, or may share this work with residents who provide care to community cats. In one canton, a PSA section has an "official volunteer" who spearheads the organization's TNR work, which involves trapping cats on her own, getting them to the vet and returning them to the field, as well as organizing resident cat caregivers all over the region to participate in the campaigns. After the surgery, regional PSA sections monitor the cat colonies "in order to be able to sterilize any new arrivals in the area in question." ${ }^{189}$ The PSA also depends on private citizens' signaling community cats to its sections, and its website provides an online form for people to do so. ${ }^{190}$

With regard to government participation, the level of local, or commune-level, involvement in or support for these operations is unknown. ${ }^{191}$ One key informant who has decades of experience carrying out TNR in multiple cantons said she did not know of any cantons that provide funding for TNR; it is possible that some do, but this information is not made available by the government. ${ }^{192}$ Scattered evidence was found of communes helping to pay for TNR operations, such as a commune in the canton of Ticino that co-financed a weeklong TNR campaign carried out by two NGOs, ${ }^{193}$ and communes that sometimes agree - upon request from an NGO - to participate in funding a TNR operation. ${ }^{194}$ Other exceptions found in the research, which will be discussed later in the section, involve a canton's financing a discreet part of TNR (though not the surgery), and local authorities' granting formal permission for non-profit groups to conduct the TNR, as opposed to governmental bodies being involved operationally.

Echoing a point made in the previous section, one key informant pointed to major differences in how animal welfare law is enforced from canton to canton. She noted that some cantonal veterinarians (who are state-appointed officials) are more supportive of TNR than are others; in particular, the cantonal veterinarian of Graubunden has put out a brochure informing each commune of how to handle feral cats, and urging them

\footnotetext{
${ }^{186}$ Walter, U. Lutter contre la misère des chats, in L'Ami des Animaux (Protection Suisse des Animaux) 1/2019

187 Written communication from PSA, 14 March 2019. For sections to receive PSA funding for TNR, they must fulfill certain conditions; see Protection Suisse des Animaux. Directives de la PSA pour la stérilisation des chats. May 2016 http://www.chatsmisere.ch/images/downloads/richtlinien/mb_katzenkastration-richtlinien_fr.pdf [Last consulted 29 May 2019]

${ }^{188}$ Written communication from PSA, 14 March 2019

${ }^{189}$ Walter, U. Lutter contre la misère..., cit. [Translated from the French: "afin de pouvoir castrer aussi d'éventuels nouveaux arrivants dans la zone en question.”]

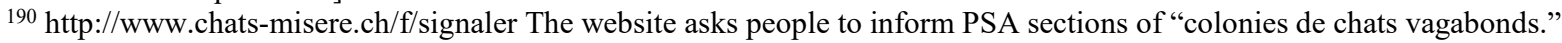

${ }^{191}$ Stiftung für das Tier im Recht, Network for Animal Protection, Stellungnahme vom 20.12.2018 zum Dokument «Fragen und Antworten zu Kastration von Freigänger-Katzen und zu Mikrochips» des Bundesamts für Lebensmittelsicherheit und Veterinärwesen (BLV) vom 3. Oktober 2018. TIR and NetAP assert that TNR is carried out by private animal welfare organizations and the extent to which "by way of exception, municipalities or cantons...carry out such castration campaigns or participate in their costs is not known" [translated from the German: "Inwieweit es ausnahmsweise Gemeinden oder Kantone gibt, die solche Kastrationsaktionen durchführen oder sich an deren Kosten beteiligen, ist nicht bekannt."]

192 Telephone interview with Esther Geisser, Founder and President, NetAP, 6 May 2019

193 Quatre Pattes. Une campagne de castration des chats (n.d.) https://fr.vier-pfoten.ch/fr/projets/animaux-errants/chats-errants-ensuisse/une-campagne-de-castration-des-chats/ [Last consulted 9 March 2019]

${ }^{194}$ Interview with Manuela Roux, Official Volunteer, SPA Valais, 25 April 2019
} 
to trap and neuter the animals. But this canton is, to her knowledge, the only one that does this. In some cantons, her organization must ask the police for permission every time it wants to carry out a castration campaign. ${ }^{195}$

Financial arrangements for spay and neuter surgery also vary across PSA's sections. To give an idea of the different arrangements: in one case, the section has enough funding that it actually subsidizes smaller organizations to do TNR; it also provides individuals with vouchers ("bons") to discount the cost of surgery for feral cats that they trap. In another instance, the surgery cost is divided between the section (which in turn receives some TNR funding from the PSA), partner veterinarians and a remaining fraction that must be recouped somehow, through contributions from the villager who traps the cat, or some other source. In yet another permutation, the SPA section splits the cost of the surgery with another NGO that is not a member of the PSA, and thus individuals trapping cats in their neighborhood do not have to pay anything. An important element is a section's having an agreement with private veterinarians who conduct the surgery at a discounted rate; all of the PSA sections interviewed mentioned having this kind of arrangement.

The PSA states that its surveys of its 71 sections in 2014 and 2017 showed that the stray cat population in Switzerland had "remained stable thanks to the PSA's program." 196 The organization also claims that, through these efforts, it has been possible "to eradicate in large part the epidemics that were spreading" before these operations began. ${ }^{197}$ As noted, the research did not turn up any publicly available scientific or statistical studies of TNR in Switzerland, either on the PSA's programs or those of other groups, so it is not possible to verify these assertions. The PSA did undertake a study in 2013 of castration campaigns by its sections, but the study remains internal and was not shared upon request.

Outside of the PSA and its sections, a number of other animal welfare organizations of varying sizes carry out TNR as well, with the crucial involvement of both volunteers, who are generally private citizens who provide assistance with castration campaigns and follow-up monitoring, and private veterinarians who spay and neuter the cats for a discounted fee. Just three of these organizations will be highlighted briefly here. One of the most well-known for its TNR work is NetAP, introduced earlier. The organization's main focus is on the welfare of farm and street animals. Its activities include spay and neuter missions in Switzerland and abroad, disaster relief and emergency aid, support for animal shelters, training veterinarians for global animal welfare missions, addressing long and illegal transports of animals for slaughter, and reporting animal rights infringements. ${ }^{198}$ NetAP trains volunteers to carry out the TNR work in Switzerland. It has contracts with about 30 veterinary clinics to do the surgery at a discount, and undertakes "Spay Days" in communes around the country. For the latter, NetAP sets up "field hospitals" near to where local volunteers trap feral cats - this can be at a town hall, a sports center, a factory, or whatever other space is available - where multiple veterinarians, volunteering their time, can operate on up to 100 cats in a weekend. These operations allow for the efficient and professional spaying and neutering of a high volume of cats. ${ }^{199}$ NetAP covers the cost of TNR for unowned cats; if the cats are on or near a farm, the organization asks the farmer for a small contribution $^{200}$ (this is similar to other groups interviewed).

The Susy Utzinger Animal Welfare Foundation (or Susy Utzinger Stiftung für Tierschutz, hereafter, SUST) is another not-for-profit with significant involvement in TNR in Switzerland. With a focus on the root causes of animal suffering, the foundation's four main pillars are improving the quality of animal shelters, neutering campaigns, education of specialists and education of the public on animal welfare. It supports neutering campaigns both abroad and locally. Its support of TNR in Switzerland involves collaborating with smaller organizations, private citizens, shelters and about 40 veterinarians carrying out TNR for cat colonies; lending out traps; covering the costs of spay and neuter surgery as well as food for neutered cat colonies; and training personnel for spay and neuter campaigns. ${ }^{201}$ The foundation, whose work is financed by private donations and legacies, also partners with SPA sections on TNR, and has a program in Switzerland to provide

\footnotetext{
195 Telephone interview with Esther Geisser, Founder and President, NetAP, 6 May 2019

${ }^{196}$ Written communication from the PSA, 14 March 2019 [Translated from the French: "la population des chats errants est resté stable grace au programme de la PSA."] Here is an example of where the term "stray cat" seems to be used too broadly, and therefore confusingly, to cover all unowned cats, including feral cats.

${ }^{197}$ Walter, U. Lutter contre la misère..., cit. [Translated from the French: "il a été possible...d'éradiquer en grande partie les épidémies que se propageaient auparavant."]

${ }^{198}$ Network for Animal Protection. About NetAP. https://www.netap.ch/en/netap [Last consulted 24 May 2019]

199 Telephone interview with, and written communication from, Esther Geisser, Founder and President, NetAP, 6 May 2019

200 Telephone interview with Esther Geisser, Founder and President, NetAP, 6 May 2019

${ }^{201}$ Susy Utzinger Stiftung für Tierschutz. Neutering Campaigns: Slowing down the Animal Misery: SUST is Tackling It Sustainably https://www.susyutzinger.ch/en/Activities/Spay-neuter-Campaigns and Susy Utzinger Stiftung für Tierschutz. Activities Switzerland https://www.susyutzinger.ch/en/Activities/Activities-Switzerland [Last consulted 22 May 2019.] This page provides a map of SUST's cat neutering campaigns in various cantons in 2018 .
} 
free spaying and neutering for animals of low-income pet owners. ${ }^{202}$ The organization reports that in 2016, it "was able to organize and finance over 400 cat neuterings in cooperation with experienced Swiss veterinarians." 203

In addition, the international animal welfare NGO, Four Paws, has global programs to neuter unowned dogs and cats. Its Swiss chapter, Vier Pfoten, or Quatre Pattes, has a program to encourage the spaying and neutering of community cats in Switzerland. Quatre Pattes carries out TNR campaigns in communes throughout the country in collaboration with other organizations. Interestingly, one of the cat colonies that Quatre Pattes has managed is at a prison in the canton of Fribourg. The group has conducted ongoing TNR actions at the prison, monitoring and then trapping and neutering any new arrivals. The cats are cared for by prisoners and prison staff. ${ }^{204}$ While Quatre Pattes organizes the TNR and lends the equipment, the prison covers the medical costs. At Quatre Pattes' initiative, the prisoners have built shelters, or "hotels", for the cats. According to a farm manager quoted in the organization's press release on the initiative, the structures not only benefit the cats; they also advance the goal of reintegration of prisoners, as their participation "has a resocializing effect by kindling their interest in animals." 205

In fact, one could argue that an informal TNR network exists in Switzerland, at least among several of the major groups working in this area. For example, NetAP cooperates with local organizations to carry out TNR of feral cat hot spots. It also has a contract of cooperation with the PSA in which the latter's sections inform NetAP of feral cat hot spots; the PSA sections then trap the cats, NetAP organizes their treatment and castration at a "field hospital", and the PSA provides a certain amount of funding per cat spayed or neutered. ${ }^{206}$ Several other key informants also pointed to working relationships they have with other groups doing TNR, in which they coordinate and split up geographical areas for castration campaigns. Only the outlines of this network emerged in the research; future investigation could perhaps provide a more concrete rendering of its contours and functioning. Besides the main groups described above, there is also an unknown number of smaller not-for-profits that conduct TNR. ${ }^{207}$

TNR operations in Switzerland are predicated not just on the need to keep the community cat population in check, but also on the need to address the sometimes cruel treatment of these animals. The PSA's TNR program is dubbed "Action against cat misery," 208 and the banner on the landing page of this program calls castration of stray and feral cats "the most animal-friendly method to prevent unwanted offspring (castrate instead of kill!)" ${ }^{209}$ Some of the key informants from animal welfare organizations told of receiving calls from residents threatening to poison feral cats or have them shot by hunters if their organization did not take the cats immediately.

In a related vein, a NetAP publication notes that the estimated cat population of Switzerland has been constant for years, but it argues that, given that only about 20,000 feral and abandoned cats annually are spayed and neutered through TNR by PSA's sections, NetAP and others, a conservative estimate is that the feral and unowned cat population in Switzerland is "regulated by killings" of as many as 100,000 cats per year. ${ }^{210}$ This number is not verifiable here, but based on NGO public materials, press coverage and key informant interviews, it is clear that community cats are still killed cruelly throughout the country, including by poisoning or being shot by hunters or farmers. These killings can be due to an individual's resistance to spending money on castrating feral cats or cats that live near farms, or a perception that feral cats are simply a nuisance to be done away with, a view that is arguably reinforced by the hunting law allowing the shooting of feral cats.

NetAP points out that such killings are unlawful in Switzerland, because although the Animal Welfare Act allows the killing of an animal, it must be done painlessly, and while euthanasia would fulfill this requirement, the Code of Ethics of the Swiss Society of Veterinarians "prohibits the killing of healthy

\footnotetext{
202 Telephone interview with Susy Utzinger, Founder and Managing Director, SUST, 24 April 2019

${ }^{203}$ Susy Utzinger Stiftung für Tierschutz. Activities Switzerland, cit.

${ }^{204}$ Quatre Pattes. Stérilisation dans les fermes et derrière les murs de la prison. 10 March 2016. https://www.quatre-pattes.ch/nosrecits/medias/archive-presse/2016/sterilisation-dans-les-fermes-et-derriere-les-murs-de-la-prison [Last consulted 11 June 2019]

${ }^{205} \mathrm{Ibid}$. [Translated from the French: "un effet de resocialization en éveillant leur intérêt pour les animaux."]

206 Telephone interview with Esther Geisser, Founder and President, NetAP, 6 May 2019

${ }^{207}$ For example, La Maison des Chats, in the canton of Vaud http://www.lamaisondeschats.ch/notre-mission.html [Last consulted 11 June 2019]

208 "Action contre la misère des chats," or "Action gegen Katzenelend"

${ }^{209}$ Protection Suisse des Animaux. Action contre la misère des chats. Web page: http://www.chats-misere.ch/f/ [Last consulted 9 July 2019] [Translated from the French: "La castration est la méthode la plus respectueuse des animaux pour empêcher des naissances indésirables (mieux vaut castrer que tuer!)"]

${ }^{210}$ Network for Animal Protection. Hochrechnung Katzentötungen..., cit. [translated from the German: "verwilderte/herrenlose/nicht betreute Katzen", and "die Katzenpopulation durch Tötungen reguliert wird.” Emphasis in original.]
} 
animals." ${ }^{211}$ It is in this context that NetAP and others have proposed "sustainable measures to avoid these unnecessary killings", including mandatory castration of outdoor (owned) cats, mandatory registration of cats so as to provide clear data on, and better control of, the cat population in Switzerland, and "banning the killing of cats for reasons of population control". ${ }^{212}$ In this way, TNR is just one part, though a crucial one, of these groups' approach to feral cat management.

\subsection{Strengths and Innovations of TNR in Switzerland}

TNR in Switzerland is marked by a number of strengths as well as promising or even innovative features. In terms of general strengths, as the previous section has outlined, there is coordination and cooperation among several organizations working on TNR and, in some cases, an explicit division of labor between groups. Examples were found of programs that have the capacity to carry out professional (i.e. veterinary) spaying and neutering of feral cats at a relatively high volume, such as NetAP's field hospitals, or the castration campaigns that several organizations conduct in communes or on farms. Importantly, practitioners in Switzerland seem well aware of the complexity of TNR, and of the need, as underscored in the theoretical and practical literature from multiple countries, to work on several levels at once: legal change and enforcement, policy advocacy, education and changing human behavior, adoption of socializable animals, support for shelters, and registration and identification of cats.

A further strength is that the sections of the PSA receive, from the national entity, a certain level of stable, if partial, funding for TNR each year, and many veterinary clinics and practices provide spay and neuter surgery for TNR programs of both the PSA sections and other organizations at a discounted rate. TNR in Switzerland also benefits from the collaboration of many volunteer cat care-givers in communities throughout the country (see box below for one example).

\section{The Centrality of Volunteers}

Manuela Roux is the "Official Volunteer" ("bénévole officielle") of SPA Valais, a section of the PSA that operates in the central and upper parts of the alpine canton of Valais. Her modest title belies the complexity of her function and the level of engagement she must maintain to carry out TNR. In addition to doing some of the trapping herself (in 2018, she trapped 290 cats: 200 adults for neutering and 90 kittens for socialization and adoption), bringing the cats to various veterinarians for neutering, returning the animals to the field after a night of recuperation at her home, and keeping detailed records of each cat neutered, she works closely with an informal network of residents - themselves also working in a voluntary capacity in villages throughout her region to ensure that they notify her when cats enter the traps, as well as reporting new (non-neutered) cats in their neighborhoods and monitoring and feeding neutered cats after they are returned to the community. Mrs. Roux also engages individually with village authorities and police, sharing information with them extensively to ensure that they will permit the TNR to take place; works to persuade those who oppose the castration campaigns; and finds the financing (whether from residents or communes) to cover the part of funding for spaying and neutering costs not covered by the SPA section and the veterinarians. In addition to her TNR work, she also provides aid to injured cats in the region. ${ }^{213}$

In their reliance on volunteers - primarily local residents who care deeply about the welfare of community cats - Swiss NGOs that carry out or organize TNR are similar to their counterparts in other countries. For example, NetAP notes that volunteers, and "the voluntary work of veterinarians," are a "central pillar" of its TNR work. ${ }^{214}$ The indispensability of volunteers to TNR is a reality wherever the method is practiced, and is confirmed in many studies on TNR worldwide. Hamilton writes, for example, that "it takes everyone in the community, both volunteers and professionals, to solve the companion animal problem." 215 The Humane Society of the United States asserts that "large-scale sterilization programs depend on volunteer

\footnotetext{
${ }^{211}$ Network for Animal Protection, Hochrechnung Katzentötungen...cit. [translated from the German: "verbietet die Tötung von gesunden Tieren."] Regarding the painless killing of animals, Bianca Körner, a lawyer with TIR, notes that the Swiss federal hunting law allows the shooting of a feral cat as long as it is done without the cat suffering, but in practical terms it is very difficult to know whether the animal suffered (telephone interview with author, 20 March 2019).

${ }^{212}$ Network for Animal Protection, Hochrechnung Katzentötungen..., cit. [translated from the German: "Nachhaltige Massnahmen zur Vermeidung dieser unnötigen Tötungen" and "Erhebung eines Verbots zur Tötung von Katzen aus Gründen der Populations kontrolle"]

${ }^{213}$ This profile is based on an interview with Manuela Roux, Official Volunteer, SPA Valais, 25 April 2019

$214 \mathrm{https}: / /$ www.kastrationspflicht.ch/de/kampagne

${ }^{215}$ Hamilton, F.E. Leading and Organizing Social Change..., cit., 187
} 
support", and notes that researchers have found that "a significant portion of the public (approximately 10\% to $12 \%$ ) already feeds community cats." 216

The unpaid work and unquestioned commitment of volunteers represent a strength of TNR: for example, they are present in the communities in a way that paid organization staff could not match, and their integral involvement in TNR is arguably a key factor in long-term, local "ownership" of the issue of community cat management. The reliance on volunteers could also be a potential weakness for TNR, in Switzerland and elsewhere, as it raises questions about sustainability, at least for individual operations. The next section will return to this issue, as well as one idea for a way forward.

Outside of the general strengths of TNR as practiced in Switzerland, the work of various organizations to manage community cats presents promising and sometimes innovative features. Just three of these will be highlighted here. Each has to do with TNR organizations' outreach to, or engagement of, different subsets of the population: farmers; local authorities, and the government and general public.

\subsubsection{Reaching Farmers}

The public perception of feral cats as "pests," ${ }^{217}$ or not worth caring about, is a common challenge to those carrying out TNR worldwide, and the next section will look at the difficulties posed to Swiss TNR practitioners of these negative attitudes in general. It is worth, however, highlighting the specific challenge of overpopulation among "chats de ferme", or cats living on or near farms in Switzerland, and the attitudes of farmers themselves. This issue was mentioned by almost all key informants, and it appears in the public materials of NGOs as well. ${ }^{218}$ One issue seems to be the outmoded notions that certain farmers (as well as members of the general population $)^{219}$ retain about cat castration: for example, that neutered animals will become "lazy" or lose their ability to hunt mice; that they will not be "normal" if they do not go through the process of bearing at least one litter; or that nature will "take its course" and keep the feral cat population in check without human intervention - notions that, as both Swiss NGOs and veterinarians have sought to point out, are not confirmed by scientific research. ${ }^{220}$ Another challenge is the concern farmers may have about the financial costs of spaying and neutering, and that, as mere "tools" to catch mice, feral cats are not worth spending money on, either for neutering or for medical care if they become sick.

In response to these issues, Swiss groups have made particular efforts to reach farmers and convince them of the benefits of TNR. To combat common misconceptions about neutering cats, as well as to lay out the arguments in favor of TNR, several NGOs that carry out TNR publish and distribute brochures (with titles such as "Cats on the Farm: Together for Healthy Cats") aimed specifically at convincing farmers to spay and neuter their cats. ${ }^{221}$ To address financial concerns, some NGOs and PSA sections organizing castration campaigns around Switzerland provide vouchers, defraying the cost of neutering for farmers who agree to castrate their cats. ${ }^{22}$ As one PSA section has asserted in relation to the vouchers offered to farmers, "often this financial support is the spark that drives many farmers to sterilize cats in their domain."223

\footnotetext{
${ }^{216}$ Humane Society of the United States. Managing Community Cats..., cit., 10, citing Levy, J.K., Crawford, P.C. Humane Strategies..., cit.

${ }^{217}$ Schaffner, J.E. Community Cats..., cit.

${ }^{218}$ For example, an information brochure on TNR published by the PSA refers to the problem of cats that "multiply in uncontrolled form on farms" ["se multiplient sous forme incontrôlée dans les fermes"] and speaks of cat owners and farmers that keep cats as two different groups. The TNR operations described are focused on feral cats (chats devenus sauvages) and farm cats. Protection Suisse des Animaux. Stériliser les chats..., cit.

${ }^{219}$ As there are apparently no surveys in Switzerland on public attitudes toward feral cats or TNR, either among the general public or specific sub-groups such as farmers, it is impossible to say how widespread these beliefs are or the extent to which various groups hold different views. The account described here is based on interviews with practitioners and a review of NGO materials.

${ }^{220}$ See Société des Vétérinaires Suisses. Papier de position de la SVS. Oui à la castration des chats - sur une base volontaire. 22 November 2018

${ }^{221}$ See, for example, Protection Suisse des Animaux, Union Suisse des Paysannes et des Femmes Rurales. Les chats à la ferme..., cit.; and Quatre Pattes. Pour des chats de ferme en bonne santé (n.d.) http://www.protectionanimaux.com/publications/animaux_de_compagnie/infothek/chats_chiens/flyer_chats_ferme.pdf [Last consulted 27 May 2019]. On refuting outmoded views of castration, see Protection Suisse des Animaux. Détention de chats conforme..., cit. and Protection Suisse des Animaux. Stériliser les chats..., cit.

${ }^{222}$ In a castration campaign in 2016 in the canton of Fribourg, for example, Quatre Pattes covered the cost of neutering 88 cats living on farms in the canton, with individual farmers receiving up to 10 vouchers that allowed them to have 10 cats neutered for free. Quatre Pattes. Castration des chats dans le canton de Fribourg lors de la journée mondiale des chats (4 August 2016). https://www.quatrepattes.ch/nos-recits/medias/archive-presse/2016/castration-des-chats-dans-le-canton-de-fribourg-lors-de-la-journee-mondiale-deschats [Last consulted 24 May 2019]

${ }^{223}$ SPA Emmental quoted in Zech, M. Une petite intervention..., cit. [translated from the French: "souvent ce soutien financier est l'étincelle qui pousse de nombreux agriculteurs à stériliser les chats de leur domaine."]
} 
In other cases, an NGO providing TNR might ask farmers to contribute financially to neutering cats trapped on or near their farms, but will cover the cost if the farmer cannot, or will not, do so. One key informant reported that her animal welfare foundation works specifically with local organizations that are already in contact with farmers due to the challenges of engaging them on spaying and neutering farm cats. She emphasized the crucial role of veterinarians in offering castration to farmers (free of charge, with her foundation covering the cost), because, as she put it, "farmers trust vets, but not animal welfare groups!"224 The PSA points out that veterinarians know the farmers in their region, and when they go to a farm to provide care for livestock, some will also distribute flyers on spaying and neutering cats. ${ }^{225}$ Notably, since 2015, two organizations - the PSA and the Union Suisse des Paysannes et des Femmes Rurales (Swiss Union of Female Farmers and Rural Women, hereafter USPF) - have carried out a joint publicity campaign on TNR. The USPF, which has 28 cantonal sections and over 57,000 individual members, ${ }^{226}$ distributes an informational leaflet yearly to its membership and posts it on its home page and on Facebook. ${ }^{227}$

It is important to nuance the picture around farmers. Several interviewees were clear that, as with any group of people, there is variation among farmers, with some supporting TNR and the groups that conduct it. Anecdotally, it was noted that younger farmers in particular seem to have a positive attitude toward neutering cats. In the canton of Geneva, while feral cats are reportedly under control in the countryside "thanks to the good collaboration of farmers," it is in the city where problems of overpopulation persist. ${ }^{228}$ This is in marked contrast to other cantons, where hot spots are more likely to be around farms. ${ }^{229}$ But even in more rural cantons, recent press articles indicate that at least some farmers are moving toward accepting neutering of their cats, ${ }^{230}$ and NetAP has been quoted as saying that "there are many exemplary farmers who castrate their cats." ${ }^{231}$ In an interesting development, PSA sections together with NetAP have carried out TNR projects with farmers, or their associations, that seem to have led to changed attitudes (toward the positive) among individual farmers as well as, at least anecdotally, a stabilization of the farm cat population in areas where the operations have been carried out. ${ }^{232}$

It is not clear whether these examples are exceptional or if, in a more positive sense, they point to an incipient trend among Swiss farmers. Future research might shed light on this. In the meantime, real challenges remain; as some key informants point out, farmers sometimes still refuse to accept neutering of farm cats even when they are offered the service for free. And cases of brutality, while perhaps not common, do continue in places. ${ }^{233}$ What the foregoing discussion does indicate is that TNR practitioners in Switzerland have formed specific strategies to engage farmers, and in some instances this work seems to be bearing results. Within the ranks of farmers themselves are allies, and TNR groups would do well to continue to find and work with these.

\subsubsection{Working with Local Authorities}

With regard to local authorities, as mentioned earlier, the extent to which cantons or communes carry out or financially support castration campaigns is unknown. ${ }^{234}$ As also outlined, groups carrying out TNR

\footnotetext{
${ }^{224}$ Telephone interview with Susy Utzinger, Founder and Managing Director, SUST, 24 April 2019

${ }^{225}$ Written communication from the PSA, 22 March 2019

226 Union Suisse des Paysannes et des Femmes Rurales. L’USPF et ses membres. https://www.paysannes.ch/fr/a-notrepropos/membres/ [Last consulted 21 June 2019]

${ }_{227}$ Written communication from Collette Basler, Co-Secretary General, USPF, 30 April 2019. The leaflet, "Les chats à la ferme: Ensemble pour des chats sains", is available at http://www.protectionanimaux.com/publications/animaux_de_compagnie/infothek/chats_chiens/flyer_chats_ferme.pdf

228 Curchod, V. Castrer votre chat? N'hésitez pas!, in Terre \& Nature, 23 March 2017. http://www.chatsmisere.ch/images/downloads/in-den-medien-fr/2017-03-23_terre_nature.pdf [Last consulted 27 May 2019] [Translated from the French: "grâce à la bonne collaboration des agriculteurs"]

${ }^{229}$ Zech, M. Une petite intervention..., cit.

${ }^{230}$ On Fribourg, for example, see Romanens, M. Les bons de castration pour chats sont encore délivrés, in Agri, 19 October 2018 , http://www.chats-misere.ch/images/2018_10_19_agri.pdf [Last consulted 27 May 2019]

${ }^{231}$ NetAP quoted in 20min.ch. Bauern sollen..., cit. [Translated from the German: "Es gebe allerdings auch viele vorbildliche Landwirte, die ihre Katzen kastrieren."]

${ }^{232}$ On initiatives in Saint Gallen and Lucern cantons, see Protection Suisse des Animaux. Operation visant à stopper la misère des chats, in Ami des Animaux, 24 March 2017. http://www.chats-misere.ch/images/downloads/in-den-medien-fr/2017-0324_ami_des_animaux.pdf [Last consulted 27 May 2019]

${ }^{233} 20 \mathrm{~min} . \mathrm{ch}$. Bauern sollen..., cit. As noted earlier, the case in this article involved a farmer in the canton of Schwytz suspected of bludgeoning a cat to death. NGOs had offered to neuter all of his cats for free, but he had refused, saying castration would hurt the cats' ability to hunt. The article quotes the PSA as saying that such cases "are rare but unfortunately they still exist" [translated from the German: "Solche Fälle sind zwar selten, aber es gibt sie leider noch immer."]

${ }^{234}$ Stiftung für das Tier im Recht, Network for Animal Protection. Stellungnahme vom 20.12.2018 zum Dokument «Fragen und Antworten zu Kastration..., cit.
} 
sometimes come up against local authorities who are opposed, or not particularly helpful, to TNR initiatives, or who arbitrarily withhold or grant permission for castration campaigns in a way that makes the work even more difficult than it already is. The research did find two examples in which TNR practitioners have succeeded in creating constructive relationships with local authorities that have allowed, or promise to allow in the future, for the advancement of castration campaigns. These are important instances, because while one could argue that they apply only in one canton or one commune, and that they would not necessarily be achievable in other parts of the country, they could have a demonstration effect for others conducting TNR in Switzerland.

In the first example, two NGOs practicing TNR in the canton of Geneva have formed an agreement with state authorities that allows them to conduct feral cat castration campaigns in the canton. The arrangement began in 2010, when SOS Chats, a section of the PSA, and the Société Genevoise pour la Protection des Animaux (hereafter, SGPA, which is not a section of the PSA), decided to work together in this area (SOS Chats had already been conducting TNR on its own for many years; SGPA had also conducted a sterilization program before 2010 but the two had not previously collaborated in this work). The NGOs eventually created a formal, written accord with the cantonal veterinary office of Geneva (Service de la Consommation et des Affaires Vétérinaires, hereafter SCAV) and the Société des Vétérinaires Genevois to carry out TNR throughout the canton and to treat sick or injured cats to the extent possible. The NGOs split the labor of TNR, trapping cats themselves as well as lending traps to individuals or groups of residents. They have negotiated financial discounts for the surgery with three private veterinary clinics, and residents monitor released cats on an ongoing basis. ${ }^{235}$

SOS Chats and SGPA cover the cost of the neutering, with SOS Chats receiving some money for this annually from the PSA. Unusually, the initiative includes microchipping the cats that have been through TNR; SCAV pays for part of the cost of vaccination and of the microchip, as well as taking care of the administrative work of registering the microchipped cats with ANIS, the centralized companion animal database. The chip indicates the cat's age, date of vaccination, the postal code of the location where the cat was captured, and the fact that the animal is registered to the canton. ${ }^{236}$

The program is innovative on several levels, and appears to be unique in Switzerland. First, it is truly multi-stakeholder, involving NGOs, private veterinarians, residents and governmental authorities. The government's level of participation - not simply allowing the operations but being an involved party that collaborates willingly - is noteworthy. Second, it is highly unusual that the government has a formal agreement to pay for part of the program - specifically, contributing towards microchipping and vaccination - and to register the microchipped feral cats in the ANIS database. Third, the microchipping element itself is unusual for TNR programs in Switzerland, and possibly for other countries, as well. In her study of the legal status of street cats in Spain, France and the UK, Dufau concluded that it is quite uncommon to find laws referring to the identification of "street cats" ("gatos callejeros") as an aspect of managing these populations. ${ }^{237}$ The Geneva TNR program is not a law, but even as a formal program, it stands out.

The president of SOS Chats, Valérie Derivaz, notes that the program is marked by a good working relationship among the different players, with the governmental authorities agreeing with the NGOs that community cats are not to be poisoned or killed, thus presenting a coherent and strong message to the public. The authorities also direct residents' complaints about these cats to the two NGOs, which work to find solutions that will not harm the cats. Derivaz cites healthier cats, a more stable population in the canton, a good level of surveillance of the cats, and a heightened public awareness about their presence, as signs that the TNR program is working. ${ }^{238}$

On a smaller scale, and only recently formed, is a written accord between the SPA Valais and Commune $X,{ }^{239}$ in the canton of Valais, to allow castration campaigns. Manuela Roux, the official volunteer of SPA Valais (see above), has formed many informal partnerships with communes in the canton to allow for TNR take place. These have been "relations of trust" ("relations de confiance"), not committed to writing;

\footnotetext{
235 This example is based on an interview with Valérie Derivaz, president, SOS Chats (Geneva), 2 April 2019 and written communications from Derivaz, 3 April 2019, 5 June 2019 and 3 July 2019.

${ }^{236}$ Ibid. The vaccination in this case is for rabies; according to Derivaz, this is a precaution taken by the program due to an increase in dog trafficking into Geneva from other countries (interview with Derivaz, 2 April 2019). The research did not find other examples of rabies vaccinations administered as part of Swiss TNR programs. This is likely because the last occurrence of rabies in wild animals in Switzerland was in 2002, and in domestic animals in 2003, according to the World Organization for Animal Health. World Organization for Animal Health. WAHIS Interface. https://www.oie.int/wahis_2/public/wahid.php/Countryinformation/animalsituation [Last consulted 10 July 2019]

${ }^{237}$ Dufau, A. Estatuto jurídico del gato callejero..., cit., 83

${ }^{238}$ Interview with Valérie Derivaz, President, SOS Chats (Geneva), 2 April 2019

${ }^{239}$ The name of the commune has been left anonymous for reasons of sensitivity.
} 
with these partnerships, once she has obtained the initial informal permission of a commune to conduct castration campaigns, she can continue working with local residents on an ongoing basis to manage local cat colonies (as noted earlier, this is not necessarily the experience of other TNR practitioners, who, depending on the commune or canton, must sometimes repeatedly ask permission from the police or local authorities to enter an area to trap cats for neutering. $)^{240}$

In the case of Commune $\mathrm{X}$, the written accord came out of a difficult experience. Roux had responded to residents' requests for help with an overpopulation of feral cats in the commune. Her efforts to discuss the requests with the police and the communal authorities went unanswered, and villagers were willing to pay for one-third of the cost of the castration campaign (with the rest covered by the SPA Valais and veterinarians), so the operation went forward. The authorities were angered, though they had not responded when originally approached for permission, and they summoned Roux and the SPA Valais to a meeting. ${ }^{241}$

After months of negotiation, the parties eventually signed an accord that authorizes Roux, as the official volunteer of the SPA Valais, to conduct spay and neuter campaigns on their communal territory. It also acknowledges that the cats will be released on their territory, and specifies that the commune will not trap community cats except in case of emergency for seriously wounded cats and that the commune will inform Roux if necessary. ${ }^{242}$ The accord is beneficial to the police, as they will not have to trap community cats; it benefits the SPA Valais because it provides clear permission for TNR in that commune; and in principle it should benefit the cats because it brings the TNR into the open and normalizes it.

Besides these examples, the research did not turn up similar instances of formal accords with communes to carry out TNR, though it is entirely possible that others exist elsewhere in the country. The two initiatives discussed above owe their existence to careful groundwork laid by the TNR practitioners to establish relationships of trust with local authorities. In fact, both Derivaz and Roux emphasized that constant dialogue and one-on-one communication are an essential part of their work, which includes convincing people of the importance of TNR and pushing back against hostile attitudes toward community cats. ${ }^{243}$ Derivaz acknowledges that Geneva is unusual in comparison to other cantons, as it is "evolved" ("évolué") in relation to animal welfare. ${ }^{244}$ But perhaps aspects of these examples could provide inspiration to others carrying out TNR in Switzerland. Even if these arrangements are not replicable in their entirety, certain aspects could be drawn on to facilitate TNR in other communes or cantons.

\subsubsection{Engaging the Government and General Public at the National Level}

A third innovative aspect to highlight is the national petition put forward by TIR and NetAP, calling for mandatory castration of outdoor (owned) cats. The petition, which garnered over 115,000 signatures, was delivered to the Swiss Parliament in June 2018. ${ }^{245}$ This section will discuss its rationale and strengths as well as criticisms or potential drawbacks of the petition.

First, a few words on petitions in Switzerland. According to the Swiss constitution, "everyone has the right, without prejudice, to petition the authorities," and the authorities "must acknowledge receipt of such petitions." ${ }^{46}$ This right "gives citizens the right to express a concern in writing to the authority in charge of some matter" and "can take the form of a request, a demand or a simple suggestion." 247 Although the petition "does not have any legal value per se," it allows people "to make their voices heard," and while authorities are not required to respond, they "generally do consider petitions and respond." 248

The petition calls on the Federal Council and Parliament to introduce mandatory castration for owned cats that are allowed outdoors, "to stem the excessive reproduction of cats and thus reduce the suffering of

\footnotetext{
240 This account of Commune X is based on an interview with Manuela Roux on 25 April 2019 and subsequent written communications from Roux (26 April 2019, 15 June 2019 and 16 June 2019).

${ }^{241}$ Ibid.

${ }^{242}$ Ibid.

${ }^{243}$ Interview with Valérie Derivaz, President, SOS Chats (Geneva), 2 April 2019 and interview with Manuela Roux, Official Volunteer, SPA Valais, 25 April 2019

${ }^{244}$ Interview with Valérie Derivaz, President, SOS Chats (Geneva), 2 April 2019. One example of how Geneva differs from other cantons in terms of animal welfare is its prohibition on hunting, as noted above in n. 175.

${ }^{245}$ Network for Animal Protection and Stiftung für das Tier im Recht. Petition, Obligation de Castration des Chats Libres de leurs Déplacements (June 2018) https://www.kastrationspflicht.ch/fr/ [Last consulted 29 May 2019]

${ }^{246} \mathrm{BV}$, Article 33, paras. 1 and 2, [Jede Person hat das Recht, Petitionen an Behörden zu richten; es dürfen ihr daraus keine Nachteile erwachsen; Die Behörden haben von Petitionen Kenntnis zu nehmen; unofficial English translation from version offered on Swiss federal government website https://www.admin.ch/opc/en/classified-compilation/19995395/index.html\#a33]

247 ch.ch. Democracy: The Swiss political system. https://www.ch.ch/en/demokratie/political-rights/petition/ [Last consulted 29 May 2019]

${ }^{248}$ Ibid.
} 
cats in Switzerland." 249 It argues that one of the main causes of the problem is that cat owners do not spay and neuter their outdoor-roaming cats, which then breed with intact, unowned (feral, stray or abandoned) cats. It also asserts that AWO article 25(4), which states that owners must take "reasonable precautions" ("zumutbaren Massnahmen") to prevent excessive breeding of their animals, ${ }^{250}$ is inadequate, and that owners cannot possibly restrict the mating behavior of their intact outdoor cats. Further, it outlines the consequences of this excessive breeding and its contribution to the population of unowned cats (spread of disease, cats dying due to lack of medical care and an estimated 100,000 unwanted cats and litters of kittens abandoned or killed each year.) The petitioners demand a modification to the regulation such that Art. 25(4) be supplemented with the wording, "free-roaming domestic cats must be castrated by a veterinarian." 251 They also point out that other countries, such as neighboring Germany and Austria, have already successfully introduced mandatory cat castration in various municipalities. ${ }^{252}$

Besides the 115,567 individual signatories (which included 39 lawmakers), over 150 organizations support the petition, as do a number of Swiss celebrities. ${ }^{253}$ The Federal Council recommended rejection of the petition as well as of a supporting motion by Doris Fiala, a National Councilor from Zurich ${ }^{254}$ though the government did not call into question the existence of feline suffering in Switzerland. ${ }^{255}$ The petition will be discussed further below. First, however, it is worth citing in detail the government's response, as well as the rejoinder by the lead petitioning groups, as these provide a more complete picture of the complexities of the debate in Switzerland on feline overpopulation.

In October 2018, four months after the petition was delivered, the PSA, the FSVO and the Société des Vétérinaires Suisses (Society of Swiss Veterinarians, hereafter, SVS) launched a responsible pet ownership campaign called Luna and Filou (to be discussed further in section 5). The same month, the FSVO published on its website its document "Questions and responses on castration of free-roaming cats and on electronic microchips," ${ }^{256}$ referred to in section 3. It is this document, which contains FSVO's position on the petition, to which NetAP and TIR responded in December 2018..$^{257}$

TIR and NetAP first take the government to task for failing to distinguish between outdoor, owned cats - the subject of the petition - and feral cats. FSVO refers in its response to an earlier, rejected petition from 2016 by another Swiss NGO that had called for castration of all cats in Switzerland, and says that it would be "disproportionate and untimely" to require the castration of "all domestic, free-roaming and stray cats" in Switzerland. The 2018 petition, however, covers exclusively owned outdoor cats, and as TIR and NetAP point out, to suggest otherwise is misleading. Likewise, the FSVO's complaint that it would be an "insurmountable burden" if the public sector were to castrate community cats is based on a willful misreading of the petition; TIR and NetAP respond that the costs of castration would be borne by cat owners, and that the petition is not calling for the state to carry out castration campaigns. To the government's argument that it could not afford costly castration campaigns, TIR and NetAP retort that castration of feral cats has always been taken care of in Switzerland by private animal welfare organizations as the state is "unwilling" ("nicht gewillt") to put money toward neutering these cats. In their view, the government's refusal to mandate castration shows that it is not only continuing to expect animal welfare organizations to shoulder the weight of solving the problem; it is also not prepared to support a solution that would ease the burden on these organizations and be "cost-

\footnotetext{
${ }^{249}$ Network for Animal Protection, Stiftung für das Tier im Recht. Petition, Obligation de Castration des Chats Libres de leurs Déplacements (June 2018) https://www.kastrationspflicht.ch/fr/ [Last consulted 29 May 2019] [Translated from the French: "pour endiguer la reproduction excessive des chats et ainsi réduire la souffrance des chats en Suisse.”]

${ }^{250} \mathrm{TSchV}$, Art. 25(4)

251 Network for Animal Protection, Stiftung für das Tier im Recht. Petition, Obligation de Castration..., cit. https://www.kastrationspflicht.ch/fr/ [translated from the French: "Les chats domestiques libres de se déplacer de manière non controlée sont à faire castrer par un vétérinaire"]

${ }^{252}$ Network for Animal Protection, Stiftung für das Tier im Recht. Petition, Obligation de Castration des Chats Libres de leurs Déplacements. Les chats de Suisse sont en grande détresse. https:/www.kastrationspflicht.ch/fr/campagne [Last consulted 29 May 2019] This point was also made by the FSVO in its response to the petition, as noted in section 3.

${ }^{253} \mathrm{https}: / /$ www.kastrationspflicht.ch/fr/supporters/celebrites Listed among the celebrities is Professor Dennis Turner, a well-known biologist, researcher and feline expert.

${ }^{254}$ Fiala's motion was entitled "Less animal suffering thanks to castration obligation for free-range cats" [Weniger Tierleid dank Kastrationspflicht für Freigängerkatzen.] It is available at https://www.parlament.ch/de/ratsbetrieb/suche-curiavista/geschaeft?AffairId=20184119 [Last consulted 19 June 2019]

${ }^{255}$ Stiftung für das Tier im Recht, NetAP, Stellungnahme vom 20.12.2018 zum Dokument «Fragen und Antworten zu Kastration..., cit.

${ }^{256}$ FSVO. Questions et réponses sur la castration..., cit.

257 Therefore where the following three paragraphs refer to the FSVO document, this is: FSVO. Questions et réponses sur la castration...cit. and where it refers to TIR and NetAP's retorts, these are from Stiftung für das Tier im Recht, Network for Animal Protection. Stellungnahme vom 20.12.2018 zum Dokument «Fragen und Antworten zu Kastration..., cit.
} 
neutral" for the state. ${ }^{258}$

To the government's claim that mandatory castration would infringe on owners' rights and create a new duty, the petitioners underscore that their petition simply calls for concretizing an existing regulation, AWO Art. 25(4), so there is no new duty foreseen. Further, they question putting animal owners' freedom above animal welfare, given that the AWA and AWO are predicated on regulating human behavior to protect animals' interests, and they argue that mandatory castration is a proportionate and sustainable measure in the face of animal suffering, and one that would bring "more legal certainty." TIR and NetAP also reject the FSVO's claim that the proposed measure would "not necessarily improve the situation of stray cats"; in their reasoning, the two groups underscore that feral cats originate primarily in private households and on farms, and by addressing this source, mandatory castration is aimed precisely at reducing the stray cat population sustainably. 259

The FSVO further claims that cantons and communes already often organize "targeted castration campaigns" for stray cats ("chats errants"), "sometimes in collaboration with animal protection organizations." TIR and NetAP reiterate that currently this task is "planned, financed and carried out" by private organizations, and the extent to which communes or cantons participate is unknown. Finally, to the FSVO's call to "better inform and sensitize all concerned rather than to regulate more", the petitioners argue that education alone will not suffice, and that Article 25(4) as currently formulated "has not reduced animal suffering."

The Society of Swiss Veterinarians (SVS), a national organization representing the professional interests of veterinarians, also responded to the petition. While acknowledging that spaying and neutering cats is recommended for medical and animal welfare reasons and to limit uncontrolled breeding, the organization argues for voluntary, not mandatory, castration of owned outdoor cats. It also states that TNR of feral cats is a "necessary and adequate measure that should continue to be supported." ${ }^{260}$ As they did for the government's response, TIR and NetAP published a detailed rebuttal of the SVS's key points in late $2018,{ }^{261}$ including the following:

- SVS's endorsement of TNR, while at the same time arguing that owners should not be obliged to spay and neuter their cats, misses the point that feral cats originate primarily in private homes, and owners are therefore part of the root of the problem;

- A voluntary approach has not worked so far in Switzerland; owners already do not obey the AWO Article 25(4), so SVS is essentially opposing "consistent implementation" of the existing regulation;

- To SVS's call for more education and sensitization, TIR and NetAP argue that many owners are not reached by information campaigns. The two groups have no objection to "comprehensive education campaigns" - these could even help cat owners accept their duty - but this should be in addition to, and not instead of, a legal obligation;

- To SVS's concern that mandatory castration would limit feline genetic diversity, TIR and NetAP argue that there are still enough feral and stray cats ("verwilderte und zugelaufene Katzen") to enrich the gene pool, and that should it prove, at a later date, that the cat population was "overregulated", the castration requirement could be "loosened."

The petition has several strengths. First, as the above detailed and careful responses to the FSVO and SVS demonstrate, the initiators have thought through multiple angles and have robust comebacks to many of the questions or criticisms raised. They even address the question of animal dignity - as discussed in section 3 , a principle enshrined in the Swiss Constitution - in giving their rationale for the petition. Namely, in their "FAQ" document to the public, they include the question, "doesn't castration affect the cat's dignity because it prevents the animal from satisfying his sexual urges or raising young"? Their response is that compromising the cat's dignity is justified in this case because it serves a higher interest. Specifically, "the interest of controlling the feline population and preventing many animals from suffering needlessly overrides the interest

\footnotetext{
${ }^{258}$ Translated from the German: "Indem das BLV die vorgeschlagene Kastrationspflicht für Freigänger-Katzen ablehnt, schiebt es zudem nicht nur die Verantwortung zur Lösung der Situation weiterhin auf Tierschutzorganisationen ab, sondern ist darüber hinaus nicht einmal bereit, eine für den Staat kostenneutrale Lösung zur Entlastung der Tierschutzorganisationen zu unterstützen."

${ }^{259}$ NetAP and TIR specifically use the term "Streunerproblem", or the stray cat problem.

${ }^{260}$ Société des Vétérinaires Suisses. Papier de position..., cit.

${ }^{261}$ The following points appear in Stiftung für das Tier im Recht, Network for Animal Protection, Stellungnahme vom 20.12.2018 zum Positionspapier "Katzen kastrieren ja - auf freiwilliger Basis" des Gesellschaft fur Schweizer Tierärztinnen un Tierärzte (GST) vom 22.11.2018 https://www.tierimrecht.org/documents/3110/NetAP-TIR-Stellungnahme-Positionspapier-GST2018-12-20.pdf
} 
of each animal and its right to satisfy his sexual desires" or right to procreate. ${ }^{262}$

Second, the petition aims to address root causes in two ways. Namely, it seeks to repair a weakness in Swiss animal welfare law: namely, the vague wording or unenforceability of AWO Art. 25(4). And it focuses on irresponsible pet ownership and its contribution to the suffering of community cats. In this context, it is worth noting that studies of TNR in other countries have emphasized the importance of addressing "contributing human behaviors (e.g. allowing owned cats to roam freely, abandoning unwanted cats)" while also implementing biological methods of control. ${ }^{263}$

Third, the petition's stated goals are ambitious: "sustainable regulation of the cat population without killing; prevention of future cat suffering; increase the chances of adoption for animals from shelters; change of mentality - cats today are sometimes perceived as 'disposable animals' whose lives are of no value and can be replaced quickly." ${ }^{264}$ Yet its approach is arguably pragmatic, asking only for a modification of an existing regulation, which would not add any new duties but would only "concretize" what the AWO calls for. Indeed, the petitioners make a point of not overreaching: the groups involved realized that, although a comprehensive solution to the problem of uncontrolled cat breeding and the suffering of community cats is complex and would involve action on many fronts, they decided to aim for one discreet change that could make a difference. For example, while mandatory microchipping could be helpful in reducing the likelihood of pet abandonment, the initiators did not want to overload the petition or mix the two issues, judging that mandatory castration could be a way to "find a rapid solution to reduce cat suffering." 265 As an aside, in 2013 a National Councilor put forward a postulate asking the Federal Council to consider and report on the appropriateness of draft legislation mandating microchipping of cats, but the motion was not pursued. ${ }^{266}$

Finally, the petitioners chose to take the issue to the national level, as animal protection is a federal competence and the cantons have "no legislative powers in this area." 267 This is one way to address the cantons' uneven approach to animal welfare enforcement discussed earlier.

Despite these strengths, there remain open questions. One is how the measure would be enforced, were the government to agree to make the change to the regulation. NetAP and TIR acknowledge the concern that " $100 \%$ respect" of mandatory spay and neuter cannot be guaranteed. ${ }^{268}$ They assert, in response, that the main purpose of the petition "is not to catch and punish as many culprits as possible;" rather, the clarity of the changed law would bring its own benefits. ${ }^{269}$ For example: veterinarians could help clients in obeying the law; animal welfare organizations carrying out TNR would no longer risk being sued for accidentally castrating owned cats (which, by the changed law, would have to have been neutered already); and shelters could immediately spay and neuter found animals without having to wait the legal minimum of two months called for in the Civil Code. The initiators insist that the Swiss population is "generally respectful of the law" and if $80 \%$ of people complied, it would represent important progress in reducing cat suffering. ${ }^{270}$

While it is undoubtedly true that an $80 \%$ compliance level would a significant improvement, it is unclear

\footnotetext{
${ }^{262}$ Network for Animal Protection, Stiftung für das Tier im Recht: Pétition...Questions et Réponses..., cit. [Translated from the French: "La castration ne porte-t-elle pas atteinte à la dignité du chat étant donné qu'elle l'empêche de satisfaire ses pulsions sexuelles ou d'élever des petits?" and "L'intérêt de contrôler la population féline et, ainsi, d'éviter que de nombreux animaux ne souffrent inutilement prime sur l'intérêt de chaque animal et son droit à satisfaire ses désirs sexuels ou de progéniture"]

${ }^{263}$ Miller, P.S., Boone, J.D., Briggs, J.R., Lawler, D.F., Levy, J.K., et al. Simulating Free-Roaming Cat Population Management Options in Open Demographic Environments. PLoS ONE 9(11): e113553 (2014). See also Natoli, E., et al. Management of Feral Domestic Cats..., cit.

${ }^{264}$ Network for Animal Protection, Stiftung für das Tier im Recht. Petition, Obligation de Castration des Chats Libres de leurs Déplacements. Les chats de Suisse sont en grande détresse, cit. [translated from the French: "Régulation durable de la population féline sans abattre d'animaux; Prévention de la souffrance future des chats; Amélioration des perspectives d'adoption des animaux venant de refuges; Changement des mentalités - Aujourd'hui, les chats sont parfois considérés comme des animaux 'jetables', dont la vie n'a aucune valeur et pouvant être remplacés facilement"]

${ }^{265}$ Network for Animal Protection, Stiftung für das Tier im Recht. Pétition...Questions et Réponses, cit. [translated from the French: "trouver une solution rapide pour réduire la souffrance des chats".] As noted in part A of this section, in the past NetAP has put forward other "sustainable measures" to prevent "unnecessary killings" of feral cats, such as "banning the killing of cats for reasons of population control" (Network for Animal Protection. Hochrechnung Katzentötungen...cit.) but NetAP and TIR acknowledge that, because Swiss law does not protect animals' lives, a ban on killing cats would be "difficult to implement politically" (Network for Animal Protection, Stiftung für das Tier im Recht. Pétition...Questions et Réponses, cit.) [Translated from the French: "difficile à mettre en oeuvre politiquement"]

${ }^{266}$ Written communication from Isabelle Schnell, Lawyer, Stiftung für das Tier im Recht, 19 June 2019. The motion, entitled "Mikrochip auch für Katzen," is available here: https://www.parlament.ch/de/ratsbetrieb/suche-curiavista/geschaeft?AffairId=20133698

${ }^{267}$ Network for Animal Protection, Stiftung für das Tier im Recht. Pétition...Questions et Réponses, cit. [translated from the French: "aucune compétence législative en la matière"]

${ }^{268}$ Network for Animal Protection, Stiftung für das Tier im Recht. Pétition...Questions et Réponses, cit.

${ }^{269}$ Ibid. [Translated from the French: "n'est pas d'attraper et de punir le plus possible de coupables"]

${ }^{270}$ Ibid. [Translated from the French: "est en général respectueuse de la loi"]
} 
how realistic that prospect is, and if the compliance percentage remained low, what the prospects would be for government enforcement of non-compliance. For comparison, Belgium has recently passed legislation mandating the neutering of owned and stray cats (the government is phasing it in between 2018 and 2020). It is the first country to do so nationally. ${ }^{271}$ According to one source, the government "has no plans to directly audit citizens' compliance" with the law. However, owners will also be required to microchip cats, who will be registered in a central database. Therefore, as one minister argued, "since registration and identification is mandatory for the whole country, sterilisation can be certified through the database." 272 Clearly this is new territory, and if enforcement and compliance remain open questions in Belgium, which has already passed a law, the same questions are probably valid for Switzerland, too.

Another question that arises in relation to the petition is financial in nature. Some TNR practitioners, particularly in the United States, have criticized the concept of mandatory spay and neuter (hereafter, MSN) as well-intentioned but misguided. Alley Cat Allies argues MSN is not effective in the U.S. because it targets only the owned cat population, most of which $(82 \%)$ is already neutered, while "ignoring" stray and feral cat populations, which are less than 3\% neutered. ${ }^{273}$ The group also argues that MSN is a "financial burden on taxpayers" and government budgets due to the costs of enforcement. ${ }^{274}$ While the petitioners in Switzerland point out that owners would pay the cost of spaying and neutering if the proposed change were made to the regulation, they do not seem to anticipate any costs for enforcing it, and although they argue (as above) that the initiative is not about punishing people, there must be some public financial implications to enforcement and compliance. This remains unanswered.

Further, Alley Cat Allies argues that resources should go to supporting spay and neuter programs in place of MSN. ${ }^{275}$ Similarly, Winograd argues that, rather than pursuing MSN, efforts should be put toward low-cost spay and neuter programs to help ensure that low-income pet owners' cats are covered. He notes that many studies have shown that intact pets "tend to belong to people with the lowest incomes." 276 Interestingly, some Swiss shelters and animal welfare organizations already cover spaying and neutering for pet owners who cannot afford it, ${ }^{277}$ and at least one instance was found of a PSA section that for years has offered free spaying and neutering to any cat owner who wants it. ${ }^{278}$ It is unclear, however, how widespread these services are in the country.

It seems that low-cost spay and neuter has not been broached in the debate around the petition, and that is a gap. The vouchers offered by PSA sections and others are obviously very important, as already discussed, but the larger criticisms of MSN raised by Alley Cat Allies and Winograd are worth probing. In addition, efforts to find data in Switzerland on sterilization rates of owned cats (much less community cats) turned up no information. These would also be useful data points for discussion. Perhaps the upshot is that MSN remains a contested topic, with disagreement among TNR practitioners about its merits and when it should be used. Or as one expert has put it, MSN should be "considered in relation to the specifics of the problem and the cat population in a particular place." 279

These gaps aside, the petition is an important step for TNR in Switzerland. Although it is not technically about TNR itself, the petition gets to the heart of, and tries to address, the same problems on which TNR is predicated: the management and ultimately the reduction of feline overpopulation through sustainable and humane measures, and the elimination of cat suffering.

The petition has been reviewed by the Committee on Science, Education and Culture of the National Council, which requested that its chamber not endorse the petition, and the National Council obliged in June 2019. It is not known when the Council of States will review the petition. ${ }^{280}$ Isabelle Schnell notes that it is difficult to evaluate the petition's prospects, and that the FSVO's rejection of mandatory castration "makes it difficult to implement this project." 281 Once a petition is rejected, there is no appeals procedure, though as

\footnotetext{
${ }^{271}$ Note that the Government of Western Australia passed the Cat Act in 2011 (coming into full effect in 2013), which requires "the compulsory identification of cats through microchipping, compulsory regulation and compulsory sterilisation.” Hiby, E., Eckman, H., MacFarlaine, I. Cat Population..., cit., p. 228.

272 Saeedy, A. Belgium is (slowly) sterilizing all its cats. EuroNews. 2 September 2018 https://www.euronews.com/2018/02/09/belgium-is-slowly-sterilising-all-its-cats [Last consulted 30 May 2019]

273 Alley Cat Allies. Missing the Target: Mandatory Spay/Neuter Legislation Fails to Reach Most Intact Cats. Fact Sheet (2017) http://4fi8v2446i0sw2rpq2a3fg51-wpengine.netdna-ssl.com/wp-content/uploads/2015/04/MSN-FactSheet.pdf

${ }^{279}$ Written communication from Harry Eckman, Co-founder and Director, Change for Animals Foundation, 10 April 2019

${ }^{280}$ Written communications from Isabelle Schnell, Lawyer, Stiftung für das Tier im Recht, 19 June 2019 and 3 July 2019

${ }^{281}$ Ibid. [translated from the French: "cela rend difficile la mise en oeuvre de ce projet"]
} 
Schnell points out, National Councilor Fiala's motion is still pending, and in any case, TIR plans "to continue to focus on raising awareness and our animal protection work in this spirit and, if necessary, to discuss new policy interventions." 282 Indeed, even if the government does not take up the petition's proposal, the process behind the petition - gathering signatures, generating publicity and triggering debate within Parliament - has arguably already played an important role in increasing awareness among the populace and among lawmakers of the problems at hand. This fits within a long line of public engagement in Switzerland on animal welfare issues, ${ }^{283}$ a point that will be taken up again briefly at the end of section 5 .

Epilogue: In late 2020, both chambers of the Swiss parliament rejected the petition, putting an end to the initiative. TIR expressed its disappointment that the parliament had "failed to commit itself to a sustainable solution to the stray animal issue. "284 It reaffirmed its commitment, along with NetAP, to keep pushing for such a solution, noting that the two groups would continue to engage with federal officials and were looking into possible cantonal-level measures. ${ }^{285}$

\section{Section 5. Advancing TNR in Switzerland: Insights from Elsewhere?}

As the previous section indicates, TNR is well-rooted in Switzerland. Many dedicated groups and individuals have built up years of experience carrying out castration campaigns in an effort to address the uncontrolled breeding of stray, abandoned and feral cats and to improve the welfare of these cats. It is evident that an informal network of TNR practitioners exists throughout the country, the exact contours of which await further research. Despite being well-established and demonstrating certain strengths and innovative features, however, TNR in Switzerland faces persistent challenges, which, in addition to weaknesses in the TNR programs themselves, need to be addressed if the method is to succeed in the country. This section explores this theme, and discusses both modifications that TNR practitioners could bring about as well as changes that will require more involvement from other sectors, such as the government and the press.

Many of the difficulties facing TNR in Switzerland are similar to those faced in other countries. Where relevant, therefore, the section brings in lessons that have emerged from elsewhere that could provide guidance for Swiss initiatives. The discussion that follows is not meant as a comprehensive review. Rather, it contemplates possible advancement through selected elements that could respond to very specific challenges uncovered in the research: namely, legal and governance-related changes (with governance referring to local governance, specifically the involvement of communes and cantons in TNR); education and changes in mentality or behavior; and technical improvements to TNR. ${ }^{286}$ Some of these changes might be easier to imagine or implement than others. But because the article is a first cut at the case study of TNR in Switzerland, this section seeks both to offer very concrete proposals for the shorter and medium term as well as to stimulate discussion about what could be feasible ways to improve its prospects in the longer term as well.

\subsection{Legal and Governance Changes}

Switzerland is considered by many to have good animal welfare laws - as one jurist puts it, "a solid basis to improve the quality of its animals' lives" - but enforcement remains an important problem. ${ }^{287}$ Both the literature and interviews with key informants confirm that even serious animal abuse often results in only light sentences for offenders. ${ }^{288}$ In its annual analysis of Swiss criminal case law in relation to animal protection, TIR has repeatedly found much room for improvement in the implementation of animal welfare

\footnotetext{
${ }^{282}$ Ibid. [translated from the French: "nous continuerons à nous concentrer sur la sensibilisation et poursuivrons notre travail de protection des animaux dans cet esprit et, si nécessaire, à discuter de nouvelles interventions politiques"]

${ }^{283}$ On public engagement in relation to animal protection, see Michel, M., Schneider Kayasseh, E. The Legal Situation..., cit.

${ }^{284}$ Stiftung für das Tier im Recht. TIR disappointed: National Council rejects mandatory neutering for outdoor cats. 11 November 2020, https://www.tierimrecht.org/en/news/2020-11-11-tir-disappointed-national-council-rejects-mandatory-neutering-for-outdoorcats/ [Last consulted 10 February 2021]

285 Ibid.

286 The discussion in section 5 owes a debt of gratitude to Schaffner (Schaffner, J.E., Community Cats...2017, cit.) for her clear identification of legal reform, attitudinal change and the marshalling of data as essential to TNR's future generally; these apply in Switzerland, as well.

${ }^{287}$ Gerritsen, V. Animal Welfare in Switzerland..., cit., 14

${ }^{288}$ Interview with Stéphane Crausaz, Responsable de la Communication, Société Vaudoise pour la Protection des Animaux, 12 March 2019; telephone interview with Bianca Körner, Lawyer, Stiftung für das Tier im Recht, 20 March 2019; and, as cited above in section 3, see Michel, M., Schneider Kayasseh, E. The Legal Situation..., cit, 16-17, Gerritsen, V. Animal Welfare in Switzerland..., cit., 3 and Bolliger, G. Legal Protection of Animal Dignity..., cit., n. 504
} 
legislation and in the prosecution and sanctioning of violations. ${ }^{289}$ Stronger enforcement of existing laws, such as the prohibition on the abandonment of animals (AWA, Article 26 (1e)), would reduce an important source of feline overpopulation, thus lowering the number of cats that TNR must address.

Another legal modification that has been discussed in Switzerland is the mandatory microchipping of cats. The initiators of the petition on mandatory castration have stated that in principle they are favorably disposed to mandatory micro-chipping and registration of cats and that it could be "an important tool" in particular to reduce the number of abandoned cats in Switzerland by increasing the disincentive for abandonment. As noted earlier, however, they have focused on mandatory castration because their main goal is feline population control; micro-chipping and registration "on its own cannot prevent unwanted reproduction" or alter cats' sexual behavior and would therefore be an additional measure, not a substitute to mandatory castration. ${ }^{290}$ In this sense, they are in agreement with other TNR proponents who point out that microchipping is only a partial solution to the problem of uncontrolled breeding of community cats.

Several interviewees lamented the lack of mandatory microchipping of pet cats in Switzerland, arguing that not only would it reduce abandonment; it would also ease the work of both animal shelters and organizations carrying out TNR. This is true for a number of reasons. Namely, a chipped (owned) cat trapped accidentally for TNR could be scanned before surgery; if the cat's owner is located, the animal could be reunited with the person. On the other hand, if the owner declined to reclaim the cat, the animal could be put up for adoption right away, without the shelter or TNR organization having to wait the two months mandated by Swiss law. Chipping would also reduce legal risks for the TNR practitioner because it would reduce the likelihood that an owned cat would be accidentally neutered without the owner's permission. While mandatory microchipping of cats is not presently a widespread practice globally, at least two other countries (Belgium ${ }^{291}$ and France ${ }^{292}$ ) have passed laws requiring registration and identification of cats, showing that it is indeed possible for governments to do so. ${ }^{293}$

The question of whether Swiss laws are used to punish TNR is one on which more research is needed; at the very least, there is some anecdotal evidence that law enforcement authorities and local lawmakers have sometimes taken punitive measures. It is not clear how much of a problem this is in comparison to other countries. In the U.S., TNR experts have noted that certain local ordinances can expose cat colony caregivers to punishment. These include the prohibition of feeding community cats ("feeding bans"), and the deeming of the "return" component of TNR to be "abandonment." 294

Similarly, the risk exists in Switzerland that certain laws could cause problems for, or even be used against, those caring for community cat colonies. To take one example, it can be difficult to determine whether a cat found in a community is owned, lost or abandoned; this is a challenge TNR practitioners face all over the world. As noted in section 3, according to Swiss law, a person who finds an animal must report it to the owner, or if he/she is unknown, to the competent authorities, and if no owner is located, the finder becomes the owner after two months have passed, at which point the person can have the animal neutered. If, however, the finder does so before the two months pass and the owner then appears, the latter could file a criminal complaint for damage to property under the Swiss Criminal Code. ${ }^{295}$ Those carrying out TNR campaigns are obviously not "finders" in the sense of people who plan to take over ownership of the cats that are being neutered; they could still, however, be subject to this provision. In this context, several Swiss TNR practitioners interviewed spoke of the efforts they make to determine whether cats are owned before they submit the animals to surgery (these measures include careful observation of a cat's behavior around people

\footnotetext{
289 Stiftung für das Tier im Recht. Animal Welfare-Related Criminal Offenses (Tierschutzstraffälle). https://www.tierimrecht.org/de/tierschutzstraffalle/ [Last consulted 24 June 2019]

${ }^{290}$ Network for Animal Protection, Stiftung für das Tier im Recht. Pétition...Questions et Réponses, cit. [Translated from the French: "l'obligation d'enregistrement seule ne peut pas prévenir les reproductions indésirables"] and Stiftung für das Tier im Recht, Network for Animal Protection. Stellungnahme vom 20.12.2018 zum Positionspapier "Katzen kastrieren ja..., cit.

${ }^{291}$ Saeedy, A. Belgium is..., cit.

292 Dufau, A. Feline Overpopulation in the EU..., cit.

${ }^{293}$ In this context, it is worth noting that mandatory chipping of dogs entered into force in Switzerland in January 2007 (Permanent Mission of Switzerland to the United Nations Office and to the other international organisations in Geneva. Manual: Pets. https://www.eda.admin.ch/missions/mission-onu-geneve/en/home/manual-regime-privileges-and-immunities/introduction/manualpets.html [Last consulted 3 June 2019]). Interestingly, some interviewees suggested that this regulation had helped reduce the canine abandonment rate. Whether that is accurate is beyond the scope of this article.

${ }^{294}$ See, for example, Holtz, E. Trap-Neuter-Return Ordinances..., cit. and Schaffner, J.E. Community Cats..., cit. For an extended discussion of the legal issues in relation to feral cats and their caregivers in the U.S., see Fry, D. Detailed Discussion of Feral Cat Legal Issues. Animal Legal \& Historical Center (Michigan State University, 2010). Fry notes that laws governing feral cats can "vary drastically" even within the same state.

${ }^{295}$ Written communication from Isabelle Schnell, Lawyer, Stiftung für das Tier im Recht, 19 June 2019. The provision in the Swiss Criminal Code is Art. 144 (Schweizerisches Strafgetzbuch, StGB, Swiss Criminal Code, in effect since 1 January 1942) https://www.admin.ch/opc/de/classified-compilation/19370083/index.html
} 
to see whether the animal is likely to be feral; distribution of notices in neighborhoods where castration campaigns will take place; and consultation of local residents to see whether anyone knows the cat and/or its owner).

In a related vein, one key informant, pointing to AWA article 6(1), which says that "anyone who keeps or looks after animals must feed and care for them properly", noted that, at least in her canton, some communes would not participate in castration campaigns because they asserted that the person who feeds community cats - and not the commune - must pay for their neutering. ${ }^{296}$ Another interviewee said that whether TNR participants faced legal obstacles in Switzerland depended on the canton, and that if the authorities thought a person was the owner because they had fed feral cats, they could give the person legal trouble. ${ }^{297}$ Schnell notes that, in Swiss law, the keeper of an animal "is defined as the person who has the actual power of decision over an animal with regard to care, use and supervision," with the decisive factor being "the power to dispose, not the legal relationship with the animal." 298 Article 6(1) of the AWA governs the duty of care toward an animal (specified in the articles 3 ss of the AWO), and, Schnell points out, "by virtue of this principle, any person who keeps or looks after animals shall feed and care for them properly and provide them with the activity and freedom of exercise needed for their well-being, as well as shelter where necessary." So "in this respect," she continues, "it is quite possible that a person who cares for stray cats, for example, feeds them and, if necessary, provides them with veterinary care, also legally assumes the status of keeper and will ultimately be responsible for these animals." 299

One way to mitigate these risks could be for cantons to provide training to communal authorities about the benefits of TNR and encouragement to work with TNR providers. The federal government does not seem to be against TNR; indeed, it claims (without providing evidence, according to the petition initiators) that cantons and communes themselves carry out targeted TNR. ${ }^{300}$ The government could therefore bolster these programs through central messaging to communes, which in principle would not cost very much, and could help address inconsistencies from one commune to another in terms of how they respond to community cat management and cat caregivers. Drawing on the examples in the previous section of positive relationships between government figures and TNR providers, future research could probe the extent to which, at least in certain cantons or communes, these could provide models for formal accords between TNR NGOs and local authorities that would explicitly permit TNR (such as in Commune X) or even promote it (as in Geneva canton). The support of local authorities in allowing TNR in their communes would make the work of providers much easier by eliminating the need to obtain permission - sometimes repeatedly - to carry out castration campaigns in each location. As an aside, it should also be noted here that one lesson from the US is that "it is not always necessary or even advantageous to pursue an ordinance if the local codes present no obstacle" to TNR. ${ }^{301}$ Formal endorsement of a TNR program by municipal authorities, or a written accord between parties, could be sufficient in some cases.

Going somewhat further, a related change could involve not just the communes' allowing TNR but their active participation in castration campaigns. As Roux points out, although the work of volunteers is essential to TNR, there are also downsides in relying completely on the benevolence of such persons. Beyond the time, energy and skills required of a TNR volunteer, they often have to contribute their own money to meet shortfalls, ${ }^{302}$ which is not necessarily practical or sustainable in the long term. For example, only Roux's gasoline costs are reimbursed by the partner communes or the SPA Valais. She suggests that if all volunteers' costs could be defrayed by communes, this could motivate more people to undertake the difficult work of trapping cats, negotiating with veterinarians, engaging with local authorities and residents, defusing conflicts in villages in relation to community cats, keeping meticulous records, and other day-to-day tasks. ${ }^{303}$

Roux further proposes that, once a commune has been stabilized (and all known community cats in the area neutered), an ideal path might be for commune employees to be trained to help with follow-up care of

\footnotetext{
${ }^{296}$ Interview with Manuela Roux, Official Volunteer, SPA Valais, 25 April 2019

297 Telephone interview with Esther Geisser, Founder and President, NetAP, 6 May 2019

${ }^{298}$ Written communication from Isabelle Schnell, Lawyer, Stiftung für das Tier im Recht, 19 June 2019 [translated from the French:

"Le détenteur d'un animal est défini comme la personne qui a le pouvoir réel de décision sur un animal en ce qui concerne les soins, l'utilisation et la surveillance. Ce qui est décisif, c'est le pouvoir de disposer, et non le lien juridique avec l'animal']

${ }^{299}$ Ibid. [translated from the French: "En vertu de ce principe, toute personne qui détient des animaux ou en assume la garde doit, d'une manière appropriée, les nourrir, en prendre soin, leur garantir l'activité et la liberté de mouvement nécessaires à leur bien-être et, s'il le faut, leur fournir un gîte...A cet égard, il est tout à fait possible qu'une personne qui s'occupe des chats errants, p. ex. les nourrit et, si nécessaire, leur fournit des soins vétérinaires, assume également légalement le statut de détenteur et sera finalement responsable de ces animaux."]

${ }^{300}$ FSVO. Questions et réponses sur la castration..., cit.

${ }^{301}$ Holtz, E. Trap-Neuter-Return Ordinances..., cit.

302 Interview with Manuela Roux, Official Volunteer, SPA Valais, 25 April 2019

${ }^{303}$ Ibid.
} 
cat colonies, and for communes to help pay for the TNR of new cats entering the area. ${ }^{304}$ Such an arrangement could address the sustainability question by making the TNR practitioners' work more manageable, sharing the costs with local government, and ensuring TNR's long-term success within communes, as it would be predicated on local buy-in and participation.

Interestingly, this proposal echoes a recommendation in the Humane Society of the US's guide to municipal leaders on managing community cats: "We strongly encourage municipalities to develop comprehensive volunteer programs and partnerships and agreements with other community organizations." 305 And the idea of formalizing the work of local volunteers has already taken shape in Barcelona, a city whose municipal TNR program formally recognizes the work of volunteer cat caregivers (for example, through training and the granting of identity badges) in a way that brings cat colony management "out of the shadows." 306

In fact, Barcelona is one of a growing number of municipal governments in various countries that work directly with animal welfare organizations and volunteers to carry out TNR. The Barcelona city council shares the costs of TNR with a group of animal welfare organizations. A 2014 ordinance, co-created by the city council and NGOs, recognizes cat colony management as the sole model for feline population control in the municipality, and calls for the city council to promote the existence of controlled cat colonies and to support the organizations that care for these colonies. ${ }^{307}$

As part of the Barcelona program, the city council's Department of Animal Welfare provides a clinic for the sterilization of feral and stray cats. ${ }^{308}$ Models exist elsewhere of municipal governments sharing the costs of TNR with NGOs. In the U.S., some city governments provide funding to non-profits to carry out TNR; according to Alley Cat Allies, this represents a "huge shift in the last 10 years," in which municipal shelters and animal control entities are "getting on board" with TNR and are willing to share responsibilities for it. ${ }^{309}$ In Rome, the 30 -year-old program to manage domestic cats is, in addition to being based in law, "financed entirely with public money." 310 Such programs, in promoting humane management of stable cat colonies, are based not only on reducing animal suffering but also on improving the chances for human-animal co-existence. As such, the programs are arguably a recognition of the right of community cats to continue living freely among human populations. ${ }^{311}$

The Swiss examples of Geneva and Commune X, discussed earlier, find certain parallels in these developments elsewhere, though it is not known whether they are isolated cases or if they contain the seeds of change for TNR locally. Lessons emerging from other countries' experiences, while not necessarily a blueprint for Switzerland, could nonetheless provide valuable guidance on using incremental legal and governance changes to facilitate and advance TNR at the municipal level.

\subsection{Altering Attitudes and Behavior: Education, Dialogue, Communication}

One could argue that bringing about the changes proposed in the previous section would be made much easier if certain attitudes could also be modified. In this context, two potential obstacles to TNR's success in Switzerland are negative mentalities toward community cats and those who care for them, and irresponsible pet ownership more broadly. Beginning with the first of these, key informant interviews, press accounts and the NGO literature point to attitudinal barriers as an important challenge to TNR work in Switzerland. These include the opinion that it is not worth the money to sterilize community cats; farmers' refusal in some cases to have farm cats neutered even if the service is offered for free; and local authorities who believe that those

\footnotetext{
${ }^{304}$ Ibid. This idea is reflected in the literature on cat population management. For example, Hiby et al argue, with regard to volunteer caregivers, that "while their involvement is crucial, a carer should not be saddled with this responsibility [of monitoring and caregiving] alone. It is essential that support is also provided by the local authorities, the wider local community, the veterinary community and local animal welfare organisations." Hiby, E., Eckman, H., MacFarlaine, I. Cat Population..., cit., p. 225.

${ }^{305}$ Humane Society of the United States. Managing Community Cats...cit., 6

${ }^{306}$ Dufau, A. Feline Overpopulation in the EU..., cit. [Translated from the Spanish: "salir de la clandestinidad".]

${ }^{307}$ Ibid. and Dufau, A. Management of Urban Cats..., cit. The law is Barcelona's L'Ordenança sobre la protecció, la tinença i la venda d'animals (2014), Article 28(1)

${ }^{308}$ Hiby, E., Eckman, H., MacFarlaine, I. Cat Population..., cit., p. 221.

309 Telephone interview with Molly Armus, Staff Attorney, Alley Cat Allies, 19 March 2019. For an example of a state-wide TNR program in the US state of Delaware, which combines non-profit animal welfare organizations, state animal control entities and intensive use of volunteers, see Bays, D. Trap-Neuter-Return on a State Scale, in Animal Sheltering Magazine, September/October 2016.

${ }^{310}$ Natoli, E., et al. Evaluation of Unowned Domestic Cat Management..., cit.

${ }^{311}$ For an interesting argument in favor of granting animals such as feral cats a limited form of citizenship ("denizenship") and the need for humans to "accept the legitimacy of their presence", see Donaldson, S. and Kymlicka, W. Zoopolis: A Political Theory of Animal Rights (Oxford University Press, 2011), 224-30.
} 
who care for cat colonies should be punished.

The problem of negative attitudes standing in the way of TNR is evident in other countries as well. In their recent study of local residents' attitudes and behavior toward community cats and neutering in an urban area in the UK, McDonald et al write that TNR "is at risk of becoming insignificant in the long-term if human behaviors and attitudes within the community are not taken into account." ${ }^{12}$ Their research found that if TNR interventions include engaging communities to understand the "drivers" of these barriers - such as "limited capability, motivation and/or opportunity" - they could have a better chance of succeeding in the long term. ${ }^{313}$ The authors' preliminary results showed that a TNR program with intensive outreach to, and engagement of, the community was "changing awareness, attitudes and behavior" toward unowned cats in a positive way. ${ }^{314}$ Moreover, they suggest that where TNR operations can be "embedded within community engagement," they can then "create a legacy of behavior change that is more likely to continue once TNR operations have ceased." 315

While some of their methods, such as the use of modeling, focus groups and community surveys to understand people's attitudes to unowned cats and neutering, might be beyond the current capacity of many Swiss TNR groups, McDonald et al also propose interventions "such as posters, social media, leaflets, public events, school visits and local TV and radio" as tools to ensure continued community involvement in TNR. ${ }^{316}$ Swiss TNR practitioners already use some of these methods, and with assistance from communes and the press, they might be able to mount the kind of comprehensive communication campaigns detailed by McDonald et al. Other mechanisms outlined in their research, such as a "drop-in point" to "build local awareness of, and trust in, the team" conducting the TNR, ${ }^{317}$ might make sense only for urban areas or larger TNR operations (as opposed to single villages) but they could still provide ideas for similar ways to reach skeptical authorities and residents in both urban and non-urban settings alike.

A recent promising example from Portugal provides further support for the role that community engagement and modifying attitudes can play in strengthening TNR efforts - and the role, in turn, that TNR can play in changing people's behavior and mentality in relation to animals. The UK charity Change for Animals Foundation (hereafter, CFAF) and its Portuguese NGO partner, Animais de Rua (hereafter, AdR), conducted a four-year dog and cat welfare project in the Algarve region between 2013 and 2017. The project included a TNR campaign aimed at vaccinating, sterilizing and treating "as high a proportion of the cat and dog population as possible". ${ }^{318}$ The initiative also sought to "promote welfare and responsible ownership to support changes in attitudes and behavior" among local residents. ${ }^{319}$ Preliminary research therefore involved not just an animal population census but a community survey, covering about $25 \%$ of the local community, to understand people's attitudes toward their animals, ownership behavior and perception of stray animals. The project was conducted on the Praia de Faro peninsula on the southern coast of Portugal; due to the location's "natural inaccessibility", the animal population is "almost completely contained with no migration." ${ }^{320}$ The year-round population is a "very poor local fishing community" that bears the brunt of caring for animals in the months outside of the summer holidays, when vacationers have gone home. These residents were brought into the project throughout its duration, and the two NGOs reported a high level of community support for the project from the outset. ${ }^{321}$

Other noteworthy features of the Praia de Faro initiative were the NGOs' collaboration with a local university to collect and test animal samples for zoonotic diseases; the use of computer modeling for the animal population census and outreach to local veterinarians to "help build bridges" between them and the local community. ${ }^{322}$ The project also involved the creation of a Veterinary Solidarity Partnership Protocol that brought together "national and local government, veterinary authorities, private vets, national and

\footnotetext{
${ }^{312}$ McDonald, J.L., Farnworth, M.J., Clements, J. Integrating Trap-Neuter-Return..., cit. Armus also states that "one of the biggest challenges facing TNR in the US are misconceptions about cats and their lives outdoors." Molly Armus, Staff Attorney, Alley Cat Allies, written communication to the author, 1 April 2019

${ }^{313}$ McDonald, J.L., Farnworth, M.J., Clements, J. Integrating Trap-Neuter-Return..., cit.

${ }^{314}$ Ibid.

315 Ibid.

316 Ibid.

${ }^{317}$ Ibid.

318 Animais da Rua, Change for Animals Foundation. Ançao Peninsula (Praia de Faro) Cat and Dog Population Management Project. First Stage Report. December 2013.

319 Ibid.

${ }^{320}$ Ibid.

${ }^{321}$ Ibid.

${ }^{322}$ Change for Animals Foundation. Praia de Faro Community Project https://www.changeforanimals.org/praia-de-faro-project [Last consulted 18 June 2019]
} 
international NGOs and the local community." ${ }^{323}$ The initiative's monitoring and evaluation stage (November 2015 - August 2017) was projected to include ongoing TNR of the cat colonies as well as working with the community and local veterinarians to continue to promote animal welfare and responsible ownership through the distribution of resources and materials. ${ }^{324}$

In their July 2015 report, CFAF and AdR estimated that "99\% of cats on Praia de Faro have been sterilized through this project." 325 Just as importantly, however, they asserted that "[h]aving built up such a close relationship with the local community means that now, when a new cat appears, they contact local partners Animais de Rua", which takes care of the cat. All cats in the area are "regularly monitored (both by the community and local AdR volunteers)." 326 CFAF and AdR also report that "one of the biggest successes" of the project has been people's change in attitude, with the local community "engaged and supportive of the work that took place and with a far greater understanding of the welfare needs of their animals." ${ }^{327}$ The Praia de Faro initiative is explicitly meant as a "model project" that can be replicated in Portugal and in other countries. ${ }^{328}$ Obviously certain aspects, such as the isolated geographical location and the advantages that this brings to TNR efforts, would not necessarily apply in the Swiss case. Other features, however, such as community engagement and the building of bridges across multiple sets of actors, could provide inspiration.

An additional way to reduce attitudinal barriers to TNR within Switzerland might be to share examples of existing accords of the type discussed in the previous section as a way to give positive experiences a "demonstration effect" and to propose potential models, even if only partial ones, that could be used in other parts of the country. Further research could determine whether other successful examples exist at the communal level in Switzerland and whether they, too, are replicable in some measure. Indeed, Roux noted that it was helpful when collaborative communes where TNR has already been conducted contact others where castration campaigns are being proposed. ${ }^{329}$ This suggests that a more systematic sharing of information among communes could contribute to changing attitudes within resistant populations. Whether this sharing should be primarily the work of NGOs, communes or the federal government, or some combination of these, is an open question.

In relation to irresponsible ownership more generally, this is a large topic that can only be touched upon here. Experts have pointed to responsible ownership, and education on this issue, as a fundamental part of the solution to feline overpopulation and the suffering of cats. ${ }^{330}$ The petition discussed in section 4 is aimed at legally requiring owners of free-roaming cats to take more responsibility for their pets by having them spayed and neutered. And it is predicated on the argument that this measure would reduce community cat populations, and thus feline suffering.

Shortly after the petition was delivered, the government launched, jointly with the PSA, the Sociéte des Vétérinaires Suisses and other veterinary associations, a responsible ownership campaign called Luna \& Filou. ${ }^{331}$ The campaign highlights the benefits of spaying and neutering as well as microchipping outdoor cats, and seeks to raise public awareness and "contribute to the health and welfare of outdoor cats." ${ }^{332}$ Its website provides information about cat ownership, identification and registration of pet cats, spaying and neutering of cats, and key legal provisions related to animal welfare and pet ownership, with links to the websites and publications of its participating organizations. As the campaign is relatively new, it is too early to tell what its impact and reach might be. In principle, a country-wide, government-supported informational campaign calling for cat owners to take responsibility for their free-roaming pets is an important tool. NetAP, however, was highly critical of the campaign, saying it "seems to serve to justify the inaction of politics" (coming, as it did, on the heels of the government's and SVS's rejection of mandatory castration), asserting that none of the organizations involved in the campaign are working on the front lines, and complaining that NetAP was

\footnotetext{
${ }^{323}$ Change for Animals Foundation, Animais da Rua. Praia de Faro Dog and Cat Management Project. November 2014 Stage 2 Report.

${ }^{324}$ Change for Animals Foundation, Animais da Rua. Praia de Faro Dog and Cat Management Project. June 2015 Stage 2.2 Report.

325 Ibid.

${ }^{326}$ Ibid.

327 Ibid.

${ }^{328}$ Ibid.

${ }^{329}$ Interview with Manuela Roux, Official Volunteer, SPA Valais, 25 April 2019

${ }^{330}$ Robertson writes, for example, "because the feral cat problem was created by humans, concerted educational efforts on responsible pet ownership and the intrinsic value of animals is an integral part of a solution." Robertson, S. A. Review of Feral Cat Control..., cit., 366. The NGO CAROcat states that responsible ownership is the "solution strategy for tackling the suffering of cats" and the "basis of individual and community commitment to cat welfare." CAROcat Responsible Ownership. About Us http://carocat.eu/aboutus/ [Last consulted 5 June 2019]

${ }^{331}$ Luna \& Filou. Campaign website: http://www.lunaundfilou.ch/fr/ [Last consulted 5 June 2019]

${ }^{332}$ FSVO. Engagement de l'OSAV dans la campagne "Luna \& Filou". Press release, 3 October 2018 http://www.protectionanimaux.com/medias/031018/pdf/02 expose f.loup_engagement_osav.pdf[Last consulted 5 June 2019] [Translated from the French: "contribuer au bien-être et à la santé des chats d'exterieur"]
} 
"deliberately not included in this campaign." 333

One could also question the federal government's general commitment to education on animal welfare. In 2014 World Animal Protection gave Switzerland a grade of "C" on "provision of humane education," noting the following: "Education in Switzerland is decentralised to canton level, and there does not appear to be a Federal requirement for animal care and protection to be included in the curricula for each canton." 334 This is despite the fact that the Animal Welfare Act states, in Article 5(2), that the federal government "ensures that the public are informed about animal welfare issues." 335 Interestingly, one key informant recounted that her foundation had written to public schools in the Swiss-German cantons offering free instruction on animal protection issues, but had gotten only one expression of interest in the offer. ${ }^{336}$ The federal government's approach to animal welfare education is beyond the scope of this article. Future research, however, could examine the government's implementation of AWA Article 5(2) and the degree to which the education curriculum could incorporate specific topics such as responsible pet ownership.

The press also has a role to play in modifying attitudes by encouraging responsible ownership, uncovering animal cruelty and raising awareness of the plight of feral, stray and abandoned cats, as well as how TNR is being used to address the problem. Several interviewees underscored the importance of media coverage of these issues, and some acknowledged that the Swiss press had been helpful in promoting castration campaigns. One TNR practitioner asserted, however, that the issue "must be in the media weekly; otherwise, people forget about it," ${ }^{337}$ underscoring the assertion in the scientific literature that for TNR to succeed, it requires consistent and ongoing maintenance and is not a one-off event. ${ }^{338}$ An interesting question about which there appears to be no research in Switzerland is the extent to which attitudes toward community cats might have changed over the years since TNR began to be practiced in the country, and since it has begun to gain more attention in the press. One interviewee with decades of experience carrying out TNR noted that, for a long time, people saw feral cats as something to get rid of. She expressed the cautiously optimistic impression that this has evolved a bit, toward where people see less of a difference between pet cats and feral cats. ${ }^{339}$

In this vein, and as touched on at the outset of the article, Schaffner calls for "reconceiving" unowned and feral cats as "members of our community" as opposed to "pests," for "reframing the debate over their management," and explicitly to use the term "community cats". ${ }^{340}$ Switzerland's multilingual aspect poses challenges for terminology. To the extent, however, that an equivalent term for "community cats" could be coined in its official languages to refer to stray, abandoned, feral, unowned and farm cats - all of which seem to be used interchangeably by those in the field - this might also help TNR practitioners to break down attitude-related barriers.

\subsection{Technical Improvements: Data and Targeted TNR}

Some of the needed changes already discussed - legal, governance, social, behavioral - will hinge in part on the actions of actors, such as government, the press and the wider public, who are not necessarily directly involved in TNR in Switzerland. Technical and operational improvements represent another important way forward, however, and these are arguably in the hands of the TNR practitioners themselves. This final sub-section will take a look at potential improvements such as the collection and use of data and the use of targeted TNR. Better data in particular could help demonstrate, in a more systematic way, that TNR can contribute to stabilizing and reducing community cat populations, reducing feline suffering and lowering the conflicts between humans and animals.

As touched upon in section 2, a persistent challenge to TNR programs in general is the collection and analysis of data and performance metrics. Wildlife biologist John Boone, writing in 2015, asserted that "many

\footnotetext{
333 Network for Animal Protection. Bundesrat will Katzenelend nicht nachhaltig bekämpfen. 23 February 2019 https:/www.netap.ch/de/aktivitaeten/kastrationen/schweiz/1686-bundesrat-will-katzenelend-nicht-bekaempfen [Last consulted 29 May 2019] [Translated from the German: "Diese Kampagne scheint vor allem dazu zu dienen, die Untätigkeit der Politik zu rechtfertigen. Keine der an dieser Kampagne beteilgiten Organisationen ist an der Front tätig. NetAP wurde in diese Kampagne bewusst nicht eingebunden."]

${ }^{334}$ World Animal Protection. Animal Protection Index..., cit., 17

335 TSchG, Article 5, para. 2 [Der Bund sorgt für die Information der Öffentlichkeit über Tierschutzfragen] [unofficial English version from: https://www.zuerchertierschutz.ch/fileadmin/user_upload/Tierschutzthemen/pdf/Tierschutzgesetz_e.pdf ]

336 Telephone interview with Susy Utzinger, Founder and Managing Director, SUST, 24 April 2019

337 Telephone interview of Esther Geisser, Founder and President, NetAP, 6 May 2019

${ }^{338}$ Boone, J.D. Better Trap-Neuter-Return..., cit., and Levy, J.K., Crawford, P.C. Humane Strategies..., cit.

${ }^{339}$ Interview with Valérie Derivaz, President, SOS Chats (Geneva), 2 April 2019

${ }^{340}$ Schaffner, J.E. Community Cats..., cit., 83 and 84
} 
TNR programs do not produce substantial and persistent reductions in cat populations, and those that do often fail to effectively document this achievement or to publicize their success," with the result being that "TNR has become increasingly controversial." ${ }^{341}$ For their part, Spehar and Wolf lament the "paucity of analyzable data" on TNR, noting that the grassroots nature of this practice "has led to inconsistent data collection." 342

At the same time, these authors and others offer recommendations on how TNR practitioners can address these challenges both by using their own resources and by partnering with others. Boone suggests TNR programs can be improved through the systematic incorporation of certain practices: for example, the target population "to be managed must be carefully defined in geographical terms" at the outset; a baseline survey of cat population size should be carried out; program goals - both population-level goals and "humane goals" such as improving cats' health - should be "explicitly formulated"; data from population surveys should be analyzed to evaluate the program; and an ongoing monitoring plan outlined. ${ }^{343}$ These and other techniques, he points out, are "not new but many are not widely practiced in TNR programs"; what is more, many of them "require only commitment and diligence to implement, not technical training." ${ }^{344}$ And where technical assistance is needed, it is often available from universities, government departments and others, with veterinarians being a key partner because of their "technical orientation and frequent involvement in TNR programs." 345 Boone also suggests computer modeling can help to measure TNR's impact on outdoor cat populations, and urges animal welfare groups to “commit to using data to learn what works and what doesn't, and adapt our operations accordingly." ${ }^{346}$ For this, he says, they can learn from working with wildlife scientists. ${ }^{347}$

Spehar and Wolf report that a new initiative "to standardize TNR program data collection and assessment" is underway, but that the effort is incipient, and "it could be some time before scientifically sound protocols are implemented on a broad scale." "I48 In the meantime, they argue that "citizen scientists" who collect data on TNR programs could offer a way forward. Their recent study of a TNR program in Chicago called Cats In My Yard (CIMY) highlights the role of the program's founder, a local resident who, over 10 years, not only carried out TNR on almost 200 cats from colonies near her home but also collected, stored and updated data on the cats as well as census information on the colonies. The authors conclude that "much potential exists for citizen science to facilitate a better understanding of the impact of TNR on free-roaming cat populations." 349 The Humane Society of the US notes that data collection and assessment allow for the identification of community cat "hotspots", which in turn provides for an accurate targeting of where to focus TNR so as to "reach a high enough rate of sterilization...to quell population growth." 350 The aforementioned study by McDonald et al provides preliminary evidence of how community engagement can help identify these hotspots. ${ }^{351}$

These findings and recommendations could be helpful in the case of Switzerland, where no scientific studies of existing TNR were found in the public domain - for example, measuring the results of castration campaigns in specific areas over extended periods of time. Anecdotally, several key informants spoke of various improvements they had seen after years of TNR activity. These included better health of local outdoor cat populations, communes where the feral cat population had stabilized or even declined, and fewer complaints by local residents about the behavior of community cats. Some of these impressions were echoed in local press articles. Backing these impressions up with numbers could help change the minds of both residents and local authorities who express skepticism or opposition to TNR or who are not convinced of its rationale for community cat management.

Data collection systems do exist within Swiss TNR practice. The PSA requires its sections to provide statistics on their TNR operations each year to account for the dedicated funds distributed. As an example, one SPA section volunteer told of the meticulous record-keeping she did for each cat in a castration campaign, including a photograph of the cat, the date and location the cat was trapped, the veterinarian who performed

\footnotetext{
${ }^{341}$ Boone, J.D. Better Trap-Neuter-Return..., cit., 800

${ }^{342}$ Spehar, D.D., Wolf, P.J. A Case Study in Citizen Science..., cit.

${ }^{343}$ Boone, J.D. Better Trap-Neuter-Return..., cit., 806. Hiby et al provide other examples of statistics that could be useful to any baseline or ongoing assessment carried out as part of a feline population management program. These include "number and type of cats relinquished to shelters"; "proportion of these that cannot be rehomed"; and "number and type of complaints received about cat populations". Hiby, E., Eckman, H., MacFarlaine, I. Cat Population..., cit., pp. 219-220.

${ }^{344}$ Boone, J.D. Better Trap-Neuter-Return..., cit. 807

${ }^{345}$ Ibid.

${ }^{346}$ John Boone cited in Lisnik, K. Reconcilable Differences..., cit.

${ }^{347}$ Ibid.

${ }^{348}$ Spehar, D.D., Wolf, P.J. A Case Study in Citizen Science..., cit.

${ }^{349}$ Ibid.

${ }^{350}$ Humane Society of the United States. Managing Community Cats..., cit., 15

${ }^{351}$ McDonald, J.L., Farnworth, M.J., Clements, J. Integrating Trap-Neuter-Return..., cit.
} 
the surgery, which PSA financial voucher was used, and so forth, all of which she reported back to her SPA section. In response to the question of whether the PSA had figures or reports on the results of its TNR operations, the PSA stated that its section surveys in 2014 and 2017 showed that "the stray cat population has remained stable thanks to the PSA's program." ${ }^{352}$ These figures, however, are internal and not shared or published, and as noted earlier, the PSA commissioned a study on TNR several years ago but it is not publicly available. As described in the previous section, community cats neutered in the Geneva TNR program are registered by the canton in a central database. And other TNR groups that are not members of the PSA also keep track of the aggregate numbers of cats sterilized yearly in their programs. ${ }^{353} \mathrm{Clearly}$, therefore, there are already some systems in place for impact measurement of TNR initiatives.

Nevertheless, important questions and challenges remain in relation to data and measurement. One interviewee with decades of TNR experience pointed out that as part of castration campaigns, data are collected on how many cats are neutered, but not information on how the TNR was done. She asserted further that a challenge in Switzerland is that TNR is not always conducted in a way that assures systematic neutering of an area's feral cats. ${ }^{354}$ Indeed, it is not clear whether and to what extent groups conducting castration campaigns are doing targeted TNR, carrying out baseline surveys or analyzing population data. Complaints and reports from local residents appear to be the basis for some - possibly many - TNR campaigns in Switzerland. ${ }^{355}$ If hot spots have been identified through formal surveys or chosen for systematic measurement of TNR impact, these instances did not turn up in the research. In the future, a more in-depth, formal investigation of Swiss castration campaigns across multiple cantons could shed light on whether this more systematic approach exists somewhere, and if it does, what results it has uncovered.

In the meantime, one way to strengthen TNR as it is practiced in Switzerland would be for local practitioners to take account of the lessons emerging from other countries about how TNR programs can improve their effectiveness and efficiency through better data collection and management, including through collaboration with veterinarians, wildlife scientists and others. Another possible step would be for academic or scientific studies to be undertaken of castration campaigns to identify results as well as ways to suggest improvements to existing techniques. These changes could also eventually help Swiss TNR programs make the case that these campaigns, in addition to being more acceptable in animal welfare terms, can be more effective and financially more sustainable in the long run than are other approaches, such as trapping and killing, or relocation of intact feral cats. ${ }^{356}$

\subsection{Moving forward}

The ground is fertile for making the changes explored in this section. Animal welfare has made strides in Switzerland over the past three decades, and there seems to be room for further evolution. In the view of Bolliger, the Swiss mentality toward animals has changed for the better, and this has pushed laws to change. He writes, specifically, that the amendment of the Swiss Civil Code in 2003 to reflect that animals are not things was meant "to reflect in the law a change in the general perception in Swiss society towards animals as sentient fellow creatures possessing dignity and, in particular, to acknowledge the increasing prevalence of pets." ${ }^{357}$ TIR asserts that in Switzerland, "animal welfare law is no longer perceived as a marginal topic, but is now recognized by attorneys-at-law and academics as an independent subject." 358 Michel and Schneider Kayasseh argue that "the Swiss public is actively engaged in questions of animal protection, and the corresponding initiatives and law changes and revisions have great resonance among the general populace and are passionately debated." 359 The outgoing director of Specialized Services of the PSA, Hansuli Huber,

\footnotetext{
${ }^{352}$ Written communication from Protection Suisse des Animaux , 14 March 2019 [Translated from the French: "L'enquête de la PSA auprès de ses 71 sections en 2014 et en 2017 a montré que la population des chats errants est resté stable grace au programme de la PSA."]

${ }^{353}$ See, for example, https://www.susyutzinger.ch/en/Activities/Activities-Switzerland. In 2014, NetAP offered a rough estimate of 20,000 cats neutered per year as part of castration campaigns by the PSA and other NGOs combined. Network for Animal Protection. Hochrechnung Katzentötungen..., cit.

354 Telephone interview with Esther Geisser, Founder and President, NetAP, 6 May 2019

${ }^{355}$ Spehar and Wolf note that targeting for TNR actions can be based on different factors, such as frequency and seriousness of resident complaints about free-roaming cats, or areas generating high numbers of cats brought to a shelter. Spehar, D.D., Wolf, P.J. Integrated Return-to-Field and Targeted..., cit.

${ }^{356}$ On financial arguments for low-cost spay/neuter versus euthanasia of healthy cats, see Hamilton, F.E. Leading and Organizing Social Change..., cit. and Humane Society of the United States. Managing Community Cats..., cit.

${ }^{357}$ Bolliger, G. Legal Protection of Animal Dignity..., cit., 360

${ }^{358}$ Stiftung für das Tier im Recht. TIR's Achievements. https://www.tierimrecht.org/en/tir-en/Achievements/ [Last consulted 26 June 2019]

${ }^{359}$ Michel, M., Schneider Kayasseh, E. The Legal Situation..., cit.
} 
reflecting on changes he had seen in Switzerland over his 30 years with the PSA, said in 2019: "The relationship between humans and animals has changed greatly. It has become much closer...Overall, I think that we can talk about a positive evolution." 360

More specifically in relation to feral cats, one veterinarian interviewed said that today there seems to be "much less euthanasia or indiscriminate shooting" and "more trapping for castration, eventual care, and release of feral cats." 361 Also on the positive side, she noted "a better understanding by the public of these campaigns and also more of a demand, both by individuals and communities, for it." 362 And Roux acknowledges that TNR is like "the work of ants," but that progress is being made; in her view, the problem of community cat proliferation "is solvable." 363

These dynamics could bode well for the changes and improvements called for here. It is time for Switzerland to take its place in the growing mosaic of TNR initiatives around the world. Its operations have something to offer to the expanding set of case studies from multiple countries. By the same token, lessons that have emerged in other places can provide inspiration and guidance for Swiss programs. An important next step would be for the Swiss case to be more fully investigated. It is to this topic that the concluding section turns.

\section{Conclusions}

This article has mapped TNR as it exists in Switzerland, and offered an analysis of how it could be strengthened. The research uncovered a well-established system of TNR in which numerous groups, on their own or in networks with one another, are figuring out innovative measures to facilitate their work, but are also facing important obstacles - legal and governance, behavioral and attitudinal, technical and operational - that they will need to address in order to succeed. These findings are important because the Swiss case offers a robust example to others seeking to learn from experiences around the world. Conversely, the findings could help Swiss practitioners identify where to put scarce resources as they strive to improve TNR and reduce feline suffering in their country.

The article was not meant as a comprehensive study of TNR in Switzerland, but rather to fill an existing gap with a snapshot that could point to strengths and weaknesses and suggest areas for further research. As such, one limitation was the inability to conduct a systematic survey of TNR in a representative sampling of cantons. Lack of publicly available data on individual TNR programs also meant it was not possible to assess the success rates of these programs in terms of feline population control, impact on human-animal relationships or changing attitudes toward community cats. At present, only aggregate figures or estimates are available, such as the number of community cats in the country, or the overall spay and neuter rates of these cats yearly by the main NGOs working in this space.

Future research, therefore, could include such a systematic survey, examining not just successful programs but also those that have failed in one way or another, and the possible reasons behind the results of each. In a related vein, the accords in Geneva and Commune $\mathrm{X}$ appear to be unusual, though perhaps there are others. A more in-depth investigation of where collaborative relationships around TNR exist between NGOs and local authorities, whether cantonal or communal, and how these have arisen, could provide clues about what constitutes a workable model in various settings in Switzerland. Further research into what appears to be the informal network among many feral cat management programs in the country could clarify how these links could be strengthened to bolster TNR overall. Any in-depth study of TNR in Switzerland should also examine other aspects of community cat management that, due to research limitations, could not be undertaken here, such as shelter management, adoption of socializable cats and colony surveillance.

In addition, it could be valuable to survey Swiss public attitudes to community cats and their management, including among specific sub-groups of the population such as farmers, in order to uncover and understand specific barriers to cat colony management (along the lines of McDonald et al's work), as well as

\footnotetext{
${ }^{360}$ Zech, M. Ces années ont été incroyablement enrichissantes, in L’Ami des Animaux 1/2019 [Translated from the French: "La relation entre l'être humain et l'animal a énormément changé. Elle est devenue bien plus étroite...Globalement, je pense qu'on peut parler d'une évolution positive."]

${ }^{361}$ Written communication from Dr. Rose-Marie Bonvin, Veterinarian, Canton of Valais, 25 April 2019 [Translated from the French: "Beaucoup moins d'euthanasie ou de tir à l'aveugle, semble-t-il, et plus de trappage pour la castration, les soins éventuels, et la remise en liberté de chats harets."]

${ }^{362}$ Ibid. [Translated from the French: "Une meilleure compréhension du public par rapport à ces campagnes et aussi plus de demande, des privés comme des collectivités, pour les faire."

${ }^{363}$ Interview with Manuela Roux, Official Volunteer, SPA Valais, 25 April 2019 [Translated from the French: "travail de fourmis" and "c'est faisable"]. Interestingly, a similar notion is expressed by Hamilton, who writes, "Animal overpopulation can be resolved. It will take a community engaged in solving the problem together." Hamilton, F.E. Leading and Organizing Social Change..., cit., 290
}

96 Derecho Animal. Forum of Animal Law Studies, vol. 12/2 
the degree to which these attitudes might be changing. This could shed light on where potential allies to TNR exist. Within such a survey, it could be enlightening to disaggregate data across groups: for example, is there a measurable difference in attitudes between younger and older farmers toward community cat management (something hinted at by some of the interviewees and in press coverage), and what are the implications for TNR? More research is also needed on the degree to which Swiss law itself poses obstacles to TNR and how to address these risks. This could include examining local regulations from canton to canton. On the flip side, to what extent do Swiss animal welfare laws present particular opportunities for TNR and how can these be used to the advantage of these programs?

Another area that remains unclear is whether and to what extent concern about feral cats' impact on wildlife might drive opposition to TNR in Switzerland. In fact, very few references to this issue were found in the research. For example, the PSA argued, in a 2012 report, that various studies including in Switzerland have shown that cats do not contribute to the disappearance of bird and reptile populations, "as is often wrongly asserted," though this is possible on oceanic islands. ${ }^{364}$ And on the question of whether cats have an impact on endangered species in the wild in Switzerland, in 2018 the Société des Vétérinaires Suisses cited a 2014 data sheet from the Swiss Ornithological Station saying that no studies had shown such an incidence, noting as well that the Station calls for neutering cats in the context of wildlife protection. ${ }^{365}$ It could be useful to know whether other research has been carried out on this point, and whether concern over feral cats' impact on wildlife in the country affects the level of receptivity to TNR in a given commune or canton, even if at present this seems to be less of an issue than it is in the United States, Australia and elsewhere.

Finally, and going beyond Switzerland, TNR is well-rooted in a variety of countries and municipalities all over the world, in both rural and urban settings of the global north and south. At the same time, it is not clear why this practice takes hold in these places in particular. Future research might explore the reasons behind its existence in some areas and not others, and the factors - political, economic, cultural and other that make its emergence and survival possible.

\section{Bibliography}

- about.ch. Information about the Economy of Switzerland. Web page: https://www.about.ch/economy/index.html\#CH_Eco_Sectors [Last consulted 15 May 2019]

- AJUNTAMENT DE BARCELONA. Benestar Animal. Area de Ecologia, Urbanisme i Mobilitat. Gats. http://ajuntament.barcelona.cat/benestaranimal/ca/gats [Last consulted 11 July 2019]

- ALLEY CAT ALLIES. Just the Facts: Community Cats. https://www.alleycat.org/resources/thetruth-about-community-cats/ [Last consulted 14 April 2021]

- ALLEY CAT ALLIES. Why Trap-Neuter-Return Feral Cats? The Case for TNR. https://www.alleycat.org/resources/why-trap-neuter-return-feral-cats-the-case-for-tnr/ [Last consulted 4 May 2019]

- ALLEY CAT ALLIES. Relocation: A Last Resort. https://www.alleycat.org/community-catcare/relocation-the-last-resort/ [Last consulted 10 July 2019]

- ALLEY CAT ALLIES. Trap-Vasectomy-Hysterectomy-Return (TVHR) Is No Substitute for TrapNeuter-Return (TNR) https://www.alleycat.org/resources/trap-vasectomy-hysterectomy-returntvhr-is-no-substitute-for-trap-neuter-return-tnr/ [Last consulted 14 June 2019]

- ALLEY CAT ALLIES. Non-surgical Sterilization for Cats? Not Yet. https://www.alleycat.org/resources/non-surgical-sterilization-for-cats-not-yet/ [Last consulted 14 June 2019]

- ALLEY CAT ALLIES. Cats and the Law (n.d.) https://www.alleycat.org/our-work/cats-and-thelaw/ [Last consulted 9 May 2019]

- ALLEY CAT ALLIES. Missing the Target: Mandatory Spay/Neuter Legislation Fails to Reach Most Intact Cats. Fact Sheet (2017) http://4fi8v2446i0sw2rpq2a3fg51-wpengine.netdnassl.com/wp-content/uploads/2015/04/MSN-FactSheet.pdf

- ALleY CAT ALliES. Feral Cats and the Public: A Healthy Relationship. https://www.alleycat.org/resources/feral-cats-and-the-public-a-healthy-relationship/ (2016) [Last consulted 17 May 2019]

\footnotetext{
${ }^{364}$ Protection Suisse des Animaux. Détention de chats conforme..., cit., 6 [Translated from the French: "comme cela est souvent prétendu à tort"]

365 Société des Vétérinaires Suisses. Papier de position..., cit., citing Station Ornithologique Suisse. Chats et oiseaux. 2014. https://www.vogelwarte.ch/fr/oiseaux/conseils/danger-pour-les-oiseaux/chats-et-oiseaux [Last consulted 1 July 2019]
} 
- ALley CAT ALLIES. Talking About Cats: Helpful Terms and Definitions. https://www.alleycat.org/resources/talking-about-cats-helpful-terms-and-definitions/ [Last consulted 17 June 2019]

- ALLEY CAT ALLIES. How to Implement an Organizational Trap-Neuter-Return Program https://www.alleycat.org/resources/how-to-implement-an-organizational-trap-neuter-returnprogram/ [Last consulted 13 May 2019]

- ALLIANCE FOR CONTRACEPTION IN CATS AND DOGS. Contraception and Fertility Control in Dogs and Cats (February 2013)

- ALLIANCE FOR CONTRACEPTION IN CATS AND DOGS. Position Statement: Modeling Study Advocating Use of Vasectomies and Hysterectomies in Feral Cat Management (2014) https://www.acc-d.org/resource-library/position-statements/acc-d-position-statement-on-mccarthyet-al [Last consulted 14 June 2019]

- AMERICAN BAR ASSOCIATION. 102B Resolution. August 14-15, 2017

- AMERICAN HUMANE ASSOCIATION. Animal Welfare Policy and Position Statements (2012) http://www.americanhumane.org/app/uploads/2016/08/animal-position.pdf [Last consulted 9 May 2019]

- AMERICAN SOCIETY FOR THE PREVENTION OF CRUELTY TO ANIMALS (ASPCA). Position Statement on Community Cats and Community Cat Programs (n.d.), https://www.aspca.org/about-us/aspca-policy-and-position-statements/position-statementcommunity-cats-and-community-cat [Last consulted 9 May 2019]

- ANIMAIS DA RUA, CHANGE FOR ANIMALS FOUNDATION. Ançao Peninsula (Praia de Faro) Cat and Dog Population Management Project. First Stage Report. December 2013

- ASOCIACIÓN DE VETERINARIOS ABOLICIONISTAS DE LA TAUROMAQUIA Y DEL MALTRATO ANIMAL (AVATMA). Informe veterinario sobre las colonias felinas y su control por el método de Captura, Esterilización y Suelta (CES). 15 October 2016 https://avatma.org/2016/10/15/informe-veterinario-sobre-las-colonias-felinas-y-su-control-por-elmetodo-de-captura-esterilizacion-y-suelta-ces/ [Last consulted 20 June 2019]

- ASSOCIATION OF SHELTER VETERINARIANS. Position Statement. Trap-Neuter-Return of Free-Roaming \& Community Cats (April 2015) https://www.sheltervet.org/assets/docs/positionstatements/trapneuterreturn.pdf [Last consulted 9 May 2019]

- BAYS, D. Trap-Neuter-Return on a State Scale, in Animal Sheltering Magazine, September/October 2016

- BOONE, J.D. Better Trap-Neuter-Return for Free-Roaming Cats: Using Models and Monitoring to Improve Population Management, in Journal of Feline Medicine and Surgery 17 (2015), 800-807

- BOURQUin, A. Chat ne peut plus durer! Protection des Animaux Suisse (9 August 2017). http://www.chats-misere.ch/images/downloads/in-den-medien-fr/2017-09-08_a_la_chaux-defonds.pdf [Last consulted 17 May 2019]

- BOlliger, G. Legal Protection of Animal Dignity in Switzerland: Status quo and Future Perspectives, in Animal Law 22 (2016)

- BRADSHAW, J. Cat Sense: The Feline Enigma Revealed (Penguin Books, 2013)

- CAROCAT RESPONSIBLE OWNERSHIP. About Us. http://carocat.eu/about-us/ [Last consulted 5 June 2019]

- CASSENS WEISS, D. Trap-Neuter-Vaccinate-Return Programs for Community Cats Backed by ABA Delegates, in ABA Journal. 14 August 2017 http://www.abajournal.com/news/article/trap_neuter_vaccinate_return_community_cats_aba_dele gates [Last consulted 4 May 2019]

- ch.ch. Democracy: The Swiss political system. Web page: https://www.ch.ch/en/demokratie/political-rights/petition/ [Last consulted 29 May 2019]

- CHANGE FOR ANIMALS FOUNDATION. Praia de Faro Community Project https://www.changeforanimals.org/praia-de-faro-project [Last consulted 18 June 2019]

- CHANGE FOR ANimAls FOUNDATION, ANIMAIS DA RUA. Praia de Faro Dog and Cat Management Project. November 2014 Stage 2 Report

- CHANGE FOR ANIMALS FOUNDATION, ANIMAIS DA RUA. Praia de Faro Dog and Cat Management Project. June 2015 Stage 2.2 Report

- CHU, K., ANDERSON, W. US Public Opinion on Humane Treatment of Stray Cats. Law \& Policy Brief (Bethesda, MD: Alley Cat Allies, September 2007)

- CURCHOD, V. Castrer votre chat? N'hésitez pas!, in Terre \& Nature (23 March 2017) 
http://www.chats-misere.ch/images/downloads/in-den-medien-fr/2017-03-23_terre_nature.pdf [Last consulted 27 May 2019]

- DONALDSON, S., KYMLICKA, W. Zoopolis: A Political Theory of Animal Rights (Oxford University Press, 2011)

- DUFAU, A. Feline Overpopulation in the EU: Abandonment and Urban Cats. Masters program in Animal Law \& Society. Universidad Autónoma de Barcelona. Powerpoint presentation, 15 February 2018

- DUFAU, A. Estatuto jurídico del gato callejero en España, Francia y Reino Unido (Tirant Lo Blanch 2017)

- DUfAU, A. Management of Urban Cats in Barcelona (April 2013) http://carocat.eu/wpcontent/uploads/2014/10/Management-of-urban-cats-in-Barcelona.pdf

- ECKMAN, H. Cat Population Management: The Human Element. Presentation, Jornadas Felinas Europeas 2016 (26 November 2016, Barcelona), available at: https://www.youtube.com/watch?v=tWp7XqC_RUc [Last accessed 18 June 2019]

- EDINBORO, C.H., WATSON, H.N., FAIRBROTHER, A. Association between a Shelter-NeuterReturn Program and Cat Health at a Large Municipal Animal Shelter, in Journal of the American Veterinary Medical Association 248:3 (1 February 2016)

- FAHRNI, D. An Outline History of Switzerland: From the Origins to the Present Day (Zurich 1994)

- FRY, D. Detailed Discussion of Feral Cat Legal Issues. Animal Legal \& Historical Center (Michigan State University, 2010)

- FURRER, S. Des solitaires farouches, in L'Ami des Animaux (Protection Suisse des Animaux) $1 / 2019$

- GERRITSEN, V. Animal Welfare in Switzerland - Constitutional Aim, Social Commitment, and a Major Challenge, in Global Journal of Animal Law GJAL 1 (January 2013)

- GIMÉNEZ-CANDELA, T. Dignity, Sentience, Personality: The Legal Relationship between Animals and Humans, in dA.Derecho Animal 9:2 (2018)

- GIMÉNEZ -CANDELA, T., The De-Objectification of Animals in the Spanish Civil Code, in dA.Derecho Animal 9:3 (2018)

- GLOBAL ANIMAL LAW PROJECT. Database legislation. Animal laws at national level Switzerland. https://www.globalanimallaw.org/database/national/switzerland/ [Last consulted 30 April 2019]

- GOBIERNO DE CEUTA. Sanidad aprueba las normas de funcionamiento para el control de colonias de gatos. 13 May $2016 \mathrm{http} / /$ www.gobiernodeceuta.es/index.php/10-sanidad-yconsumo/8307-sanidad-aprueba-las-normas-de-funcionamiento-para-el-control-de-colonia-degatos [Last consulted 11 July 2019]

- GREENFIELDBOYCE, N. North America Has Lost 3 Billion Birds, Scientists Say. National Public Radio. 19 September 2019.

- GRUPO DE ESPECIALIDAD DE MEDICINA FELINA DE LA ASOCIACIÓN DE VETERINARIOS ESPAÑOLES ESPECIALISTAS EN PEQUEÑOS ANIMALES (GEMFEAVEPA). Posicionamiento GEMFE-AVEPA sobre las colonias felinas urbanas (n.d.) https://avepa.org/pdf/GRUPOSTRABAJO/POSICIONAMIENTO_Colonias_Felinas.pdf [Last consulted 9 May 2019]

- GUNTHER, I., RAZ, T., EVEN ZOR, Y., BACHOWSKI, Y., KLEMENT, E. Feeders of FreeRoaming Cats: Personal Characteristics, Feeding Practices, and Data on Cat Health and Welfare in an Urban Setting of Israel, in Frontiers in Veterinary Science 3:21 (2016) doi: $10.3389 /$ fvets.2016.00021

- HAMILTON, F.E. Leading and Organizing Social Change for Companion Animals, in Anthrozoös 23:3 (2010), 277-292. doi: 10.2752/175303710X12750451259057

- HIBY, E., ECKMAN, H., MACFARLAINE, I. Cat Population Management in D.C. Turner and P. Bateson (Eds.,), The Domestic Cat: The Biology of its Behaviour ( $3^{\text {rd }}$ ed.) (Cambridge University Press, 2014)

- HOLTZ, E. Trap-Neuter-Return Ordinances and Policies in the United States: The Future of Animal Control. Law \& Policy Brief (Bethesda, MD: Alley Cat Allies, January 2013)

- HUMANE SOCIETY OF THE UNITED STATES. Managing Community Cats: A Guide for Municipal Leaders. 2014

- HUMANE SOCIETY OF THE UNITED STATES. Our Position on Cats. https://www.humanesociety.org/resources/our-position-cats\#unowned_cats (n.d.) [Last consulted 9 
May 2019]

- INTERNATIONAL SOCIETY OF FELINE MEDICINE (ISFM). ISFM Guidelines on Population Management and Welfare of Unowned Domestic Cats (felis catus) in Journal of Feline Medicine and Surgery 15 (2013), 811-817

- JOHNSON, K.L., CICIRELLI, J. Study of the Effect on Shelter Cat Intakes and Euthanasia from a Shelter Neuter Return Program of 10,080 Cats from March 2010 to June 2014, in PeerJ 2:e646 (2014) doi: 10.7717/peerj.646

- KREISLER, R.E., CORNELL, H.N., LEVY, J.K. Decrease in Population and Increase in Welfare of Community Cats in a Twenty-Three Year Trap-Neuter-Return Program in Key Largo, FL: The ORCAT Program, in Frontiers in Veterinary Science 6:7 (2019) doi: 10.3389/fvets.2019.00007

- LAZENBY, B.T., MOONEY, N.J., DICKMAN, C.R. Effects of Low-Level Culling of Feral Cats in Open Populations: A Case Study from the Forests of Southern Tasmania, in Wildlife Research 41:5 (2014), 407-420

- LEVY, J.K. Contraceptive Vaccines for the Humane Control of Community Cat Populations, in American Journal of Reproductive Immunology 66 (2011), 63-70 doi: 10.1111/j.16000897.2011.01005.x

- LEVY, J.K., CRAWFORD, P.C. Humane Strategies for Controlling Feral Cat Populations, in Journal of the American Veterinary Medical Association 225:9 (2004), 1354-1360

- LEVY, J., ISAZA, N.M., SCOTT, K.C. Evaluation of High-Impact Targeted Trap-Neuter-Return and Adoption of Community Cats on Cat Intake to a Shelter, in The Veterinary Journal 201 (2014)

- LEVY, J.K., GALE, D.W., GALE, L.A. Evaluation of a Long-term Trap-Neuter-Return and Adoption Program on a Free-roaming Cat Population, in Journal of the American Veterinary Medical Association 222:1 (1 January 2003)

- LISNIK, K. Reconcilable Differences: Wildlife Biologist Helps Chart a New Path for Cat Advocates and Conservationists, Animal Sheltering Magazine (Fall 2017) https://www.animalsheltering.org/magazine/articles/reconcilable-differences-0 [Last consulted 16 May 2019]

- LUNA \& FILOU. Information flyer. Protection des Animaux Suisse . Web page: http://www.protectionanimaux.com/publications/animaux_de_compagnie/infothek/chats_chiens/flyer_lunafilou_fr.pdf [Last consulted 17 May 2019]

- LUNA \& FILOU. Campaign website: http://www.lunaundfilou.ch/fr/ [Last consulted 5 June 2019]

- MCCARTHY, R, LEVINE, S.H., REED, J.M. Estimation of Effectiveness of Three Methods of Feral Cat Population Control by Use of a Simulation Model in Journal of the American Veterinary Medical Association 243:4 (15 August 2013)

- MCDONALD, J.L., FARNWORTH, M.J., CLEMENTS, J. Integrating Trap-Neuter-Return Campaigns into a Social Framework: Developing Long-Term Positive Behaviour Change Toward Unowned Cats in Urban Areas, in Frontiers in Veterinary Science 5:258 (2018)

- MICHEL, M., SCHNEIDER KAYASSEH, E. The Legal Situation of Animals in Switzerland: Two Steps Forward, One Step Back - Many Steps to Go, in Journal of Animal Law VII (2011)

- MILLER, P.S., BOONE, J.D., BRIGGS, J.R., LAWLER, D.F., LEVY, J.K., ET AL. Simulating Free-Roaming Cat Population Management Options in Open Demographic Environments. PLoS ONE 9:11: e113553 (2014) doi: 10.1371/journal.pone.0113553

- NATOLI, E. ET AL. Evaluation of Unowned Domestic Cat Management in the Urban Environment of Rome after 30 Years of Implementation of the No-Kill Policy (National and Regional Laws), in Frontiers in Veterinary Science 6:31 (2019)

- NATOLI, E. ET AL. Management of Feral Domestic Cats in the Urban Environment of Rome (Italy), in Preventive Veterinary Medicine 77 (2006), 180-185 doi:10.1016/j.prevetmed.2006.06.005

- NETWORK FOR ANIMAL PROTECTION. About NetAP. Web page: https://www.netap.ch/en/netap [Last consulted 24 May 2019]

- NETWORK FOR ANIMAL PROTECTION. Verwilderte Katzen - was tun? Wegweiser Nr. 3, 2016

- NETWORK FOR ANIMAL PROTECTION, Hochrechnung Katzentötungen Schweiz (10 September 2014) https:/www.netap.ch/images/Downloads/100000Katzentoetungen_Zahlen_201400910-Berechnumg-NetAP.pdf

- NETWORK FOR ANIMAL PROTECTION. Kastrationspflicht - Schweiz. https://www.netap.ch/de/aktivitaeten/recht-und-politik/kastrationspflicht-schweiz [Last consulted 17 May 2019] 
- NETWORK FOR ANIMAL PROTECTION. Bundesrat will Katzenelend nicht nachhaltig bekämpfen (23 February 2019) https://www.netap.ch/de/aktivitaeten/kastrationen/schweiz/1686bundesrat-will-katzenelend-nicht-bekaempfen [Last consulted 29 May 2019]

- NETWORK FOR ANIMAL PROTECTION, TIER IM RECHT. Petition, Obligation de Castration des Chats Libres de leurs Déplacements (June 2018) https://www.kastrationspflicht.ch/fr/ [Last consulted 29 May 2019]

- NETWORK FOR ANIMAL PROTECTION, TIER IM RECHT. Petition, Obligation de Castration des Chats Libres de leurs Déplacements. Les chats de Suisse sont en grande détresse. https://www.kastrationspflicht.ch/fr/campagne [Last consulted 29 May 2019]

- NETWORK FOR ANIMAL PROTECTION, TIER IM RECHT. Pétition: Obligation de Castration des Chats libres de leurs Déplacements. Questions et Réponses https://www.kastrationspflicht.ch/fr/faq [Last consulted 15 May 2019]

- NUTTER, F.B. Evaluation of a Trap-Neuter-Return Management Program for Feral Cat Colonies: Population Dynamics, Home Ranges, and Potentially Zoonotic Diseases. Ph.D. Thesis, North Carolina State University (Raleigh, N.C., 2005). Available online at: https://repository.lib.ncsu.edu/bitstream/handle/1840.16/3891/etd.pdf?sequence=1\&isAllowed=y [Accessed 4 May 2019]

- PERMANENT MISSION OF SWITZERLAND TO THE UNITED NATIONS OFFICE AND TO THE OTHER INTERNATIONAL ORGANISATIONS IN GENEVA. Manual: Pets. https://www.eda.admin.ch/missions/mission-onu-geneve/en/home/manual-regime-privileges-andimmunities/introduction/manual-pets.html [Last consulted 3 June 2019]

- PROTECTION SUISSE DES ANIMAUX. À propos de nous. http://www.protectionanimaux.com/psa/index.html [Last consulted 28 June 2019]

- PROTECTION SUISSE DES ANIMAUX. Animaux de compagnie. http://www.protectionanimaux.com/animaux_de_compagnie/index.html [Last consulted 17 May 2019]

- PROTECTION SUISSE DES ANIMAUX, UNION SUISSE DES PAYSANNES ET DES FEMMES RURALES. Les chats à la ferme: Ensemble pour des chats sains (n.d.) http://www.protection-

animaux.com/publications/animaux_de_compagnie/infothek/chats_chiens/flyer_chats_ferme.pdf [Last consulted 9 July 2019]

- PROTECTION SUISSE DES ANIMAUX. Directives de la PSA pour la stérilisation des chats. May $2016 \mathrm{http} / / / \mathrm{www} . c h a t s-m i s e r e . c h /$ images/downloads/richtlinien/mb_katzenkastrationrichtlinien_fr.pdf

- PROTECTION SUISSE DES ANIMAUX. Operation visant à stopper la misère des chats, in Ami des Animaux (24 March 2017) http://www.chats-misere.ch/images/downloads/in-den-medienfr/2017-03-24_ami_des_animaux.pdf

- PROTECTION SUISSE DES ANIMAUX. Service Spécialisé "Contrôles Protection des Animaux". Rapport d'activité de juin 2017 à mai 2018

- PROTECTION SUISSE DES ANIMAUX. Rapport Annuel 2018

- PROTECTION SUISSE DES ANIMAUX. Action contre la misère des chats http://www.chatsmisere.ch/kampagne/ueber-die-kampagne [Last consulted 9 July 2019]

- PROTECTION SUISSE DES ANIMAUX. Chiffres et faits. Statistique protection des animaux 2017/Rapport "contrôles protection des animaux." Communiqué de press 30 octobre 2018 http://www.protection-animaux.com/medias/pc2018/301018.html [Last consulted 17 May 2019]

- PROTECTION SUISSE DES ANIMAUX. Statistique protection des animaux/Contrôles protection des animaux (30 October 2018) http://www.protectionanimaux.com/medias/statistique2017/index.html [Last consulted 17 May 2019]

- PROTECTION SUISSE DES ANIMAUX. Stériliser les chats au lieu de tuer. Feuille d'information (October 2015) http://www.chats-misere.ch/images/downloads/mb_katzenkastration_fr.pdf

- PROTECTION SUISSE DES ANIMAUX. Détention de chats conforme à l'espèce: Guide pratique. November 2012 www.protectionanimaux.com/publications/animaux_de_compagnie/docs/detention_chats.html [Last consulted 27 May 2019]

- QUATRE PATTES. Pour des chats de ferme en bonne santé (n.d.) https://media.4paws.org/9/f/4/e/9f4e4a13338ff53703a924f2fd9296302e37c80d/Brochure\%20sur\%201es\%20chats $\% 20 \mathrm{de} \% 20$ ferme $\% 20-\% 20$ FR.pdf [Last consulted 27 May 2019]

- QUATRE PATTES. Une campagne de castration des chats (n.d.) https://fr.vier- 
pfoten.ch/fr/projets/animaux-errants/chats-errants-en-suisse/une-campagne-de-castration-deschats/ [Last consulted 9 March 2019]

- QUATRE PATTES. Castration des chats dans le canton de Fribourg lors de la journée mondiale des chats (4 August 2016). https://www.quatre-pattes.ch/nos-recits/medias/archivepresse/2016/castration-des-chats-dans-le-canton-de-fribourg-lors-de-la-journee-mondiale-deschats [Last consulted 24 May 2019]

- QUATRE PATTES. Stérilisation dans les fermes et derrière les murs de la prison. 10 March 2016. https://www.quatre-pattes.ch/nos-recits/medias/archive-presse/2016/sterilisation-dans-les-fermeset-derriere-les-murs-de-la-prison [Last consulted 11 June 2019]

- ROBERTSON, S. A. Review of Feral Cat Control, in Journal of Feline Medicine and Surgery 10 (2008), 366-375

- ROMANENS, M. Les bons de castration pour chats sont encore délivrés, in Agri, 19 October 2018, http://www.chats-misere.ch/images/2018_10_19_agri.pdf [Last consulted 27 May 2019]

- SAEEDY, A. Belgium is (slowly) sterilizing all its cats. EuroNews. 2 September 2018 https://www.euronews.com/2018/02/09/belgium-is-slowly-sterilising-all-its-cats [Last consulted 20 May 2019]

- SCHAFFNER, J.E. Cat Wars: The Devastating Consequences of a Dangerous Book, review of P. Marra and C. Santella, Cat Wars: The Devastating Consequences of a Cuddly Killer, in Journal of Animal Ethics 8:2 (2018)

- SCHAFFNER, J.E. Community Cats: Changing the Legal Paradigm for the Management of SoCalled "Pests". Syracuse Law Review 67:71 (2017)

- SCOTT, K.C., LEVY, J.K., CRAWFORD, P.C. Characteristics of Free-Roaming Cats Evaluated in a Trap-Neuter-Return Program, in Journal of American Veterinary Medical Association. 221:8 (15 October 2002) doi 10.2460/javma.2002.221.1136

- SLATER, M.R., SHAIN, S. Feral Cats: An Overview in D.J. SALEM and A.N. ROWAN (Eds.), The State of the Animals III (Washington, D.C., Humane Society Press, 2005)

- SOCIÉTÉ DES VÉTÉRINAIRES SUISSES. Papier de position de la SVS. Oui à la castration des chats - sur une base volontaire. 22 November 2018

- SPEHAR, D.D., WOLF, P.J. Integrated Return-to-Field and Targeted Trap-Neuter-VaccinateReturn Programs Result in Reductions of Feline Intake and Euthanasia at Six Municipal Animal Shelters, in Frontiers in Veterinary Science 6:77 (2019) doi 10.3389/fvets.2019.00077

- SPEHAR, D.D., WOLF, P.J. A Case Study in Citizen Science: The Effectiveness of a Trap-NeuterReturn Program in a Chicago Neighborhood, in Animals 8:14 (2018) doi 10.3390/ani8010014

- SPEHAR, D.D., WOLF, P.J. An Examination of an Iconic Trap-Neuter-Return Program: The Newburyport, Massachusetts Case Study, in Animals 7:81 (2017) doi 10.3390/ani7110081

- STATION ORNITHOLOGIQUE SUISSE. Chats et oiseaux. 2014. https://www.vogelwarte.ch/fr/oiseaux/conseils/danger-pour-les-oiseaux/chats-et-oiseaux [Last consulted 1 July 2019]

- STEINBERG, J. Why Switzerland? (Cambridge University Press, second edition, 1996)

- STIFTUNG FÜR DAS TIER IM RECHT. TIR disappointed: National Council rejects mandatory neutering for outdoor cats. 11 November 2020, https://www.tierimrecht.org/en/news/2020-11-11tir-disappointed-national-council-rejects-mandatory-neutering-for-outdoor-cats/ [Last consulted 10 February 2021]

- STIFTUNG FÜR DAS TIER IM RECHT. TIR's Achievements. https://www.tierimrecht.org/en/tiren/Achievements/ [Last consulted 26 June 2019]

- STIFTUNG FÜR DAS TIER IM RECHT. Animal Welfare-Related Criminal Offenses (Tierschutzstraffälle) https://www.tierimrecht.org/de/tierschutzstraffalle/ [Last consulted 24 June 2019]

- STIFTUNG FÜR DAS TIER IM RECHT, NETWORK FOR ANIMAL PROTECTION. Stellungnahme vom 20.12.2018 zum Dokument "Fragen und Antworten zu Kastration von Freigänger-Katzen und zu Mikrochips" des Bundesamts für Lebensmittelsicherheit und Veterinärwesen (BLV) vom 3. Oktober 2018

- STIFTUNG FÜR DAS TIER IM RECHT, NETWORK FOR ANIMAL PROTECTION. Stellungnahme vom 20.12.2018 zum Positionspapier "Katzen kastrieren ja - auf freiwilliger Basis" des Gesellschaft fur Schweizer Tierärztinnen un Tierärzte (GST) vom 22.11.2018 https://www.tierimrecht.org/documents/3110/NetAP-TIR-Stellungnahme-PositionspapierGST2018-12-20.pdf 
- STIFTUNG FÜR DAS TIER IM RECHT, NETWORK FOR ANIMAL PROTECTION. Stellungnahme zum Entscheid des Ständerats zur Ablehnung der Petition von „SOS Chats“ zur Einführung einer obligatorischen Kastrationspflicht für Katzen (16 December 2016) https://www.netap.ch/images/Projekte/Kastrationen/Schweiz/NetAP_Stellungnahme_Ablehnung Petition_SOS_Chats_20161216_Final.pdf

- SUSY UTZINGER STIFTUNG FÜR TIERSCHUTZ. Neutering Campaigns: Slowing down the Animal Misery: SUST is Tackling It Sustainably https://www.susyutzinger.ch/en/Activities/Spayneuter-Campaigns [Last consulted 22 May 2019.]

- SUSY UTZINGER STIFTUNG FÜR TIERSCHUTZ. Activities Switzerland https://www.susyutzinger.ch/en/Activities/Activities-Switzerland [Last consulted 22 May 2019]

- SWARBRICK, H., RAND, J. Application of a Protocol Based on Trap-Neuter-Return (TNR) to Manage Unowned Urban Cats on an Australian University Campus, in Animals 8:77 (2018) doi: 10.3390/ani8050077

- SWISS CONFEDERATION. Objectifs stratégiques assignés à Identitas SA par le Conseil fédéral pour les années 2019 à 2022. 1 June 2018 https://www.admin.ch/opc/fr/federalgazette/2018/3947.pdf

- SWISS CONFEDERATION. Federal Statistical Office. Population. https://www.bfs.admin.ch/bfs/en/home/statistics/population.html [Last consulted 15 May 2019]

- SWISS CONFEDERATION. Federal Statistical Office. Communes. https://www.bfs.admin.ch/bfs/en/home/statistics/regional-statistics/regional-portraits-keyfigures/communes/portraits-communes.html [Last consulted 15 May 2019]

- SWISS CONFEDERATION. Swiss Political System - Facts and Figures. https://www.eda.admin.ch/aboutswitzerland/en/home/politik/uebersicht/politisches-system-derschweiz---fakten-und-zahlen.html [Last consulted 15 May 2019]

- SWISS FEDERAL COUNCIL. The Swiss Veterinary Service https://www.blv.admin.ch/blv/en/home/das-blv/organisation/veterinaerdienst-schweiz.html [Last consulted 21 June 2019]

- SWISS FEDERAL FOOD SAFETY AND VETERINARY OFFICE. Questions et réponses sur la castration des chats libres de leurs déplacements et sur les puces électroniques. 3 octobre 2018 https://www.blv.admin.ch/dam/blv/fr/dokumente/tiere/heim-und-wildtierhaltung/faq-katzenkastration-mikrochips.pdf.download.pdf/Katzen-Kastrieren___Fragen_und_Antworten_FR.pdf [Last consulted 21 June 2019]

- SWISS FEDERAL FOOD SAFETY VETERINARY OFFICE. Engagement de l'OSAV dans la campagne "Luna \& Filou". Press release, 3 October 2018 http://www.protectionanimaux.com/medias/031018/pdf/02_expose_f.loup_engagement_osav.pdf [Last consulted 5 June 2019]

- UNION SUISSE DES PAYSANNES ET DES FEMMES RURALES. L'USPF et ses membres. https://www.paysannes.ch/fr/a-notre-propos/membres/ [Last consulted 21 June 2019]

- WALTER, U. Lutter contre la misère des chats, in L'Ami des Animaux, 1/2019

- WINOGRAD, N.J. Redemption: The Myth of Pet Overpopulation and the No Kill Revolution in America (Almaden Books, 2007)

- WOLF, P.J., SCHAFFNER, J.E. The Road to TNR: Examining Trap-Neuter-Return through the Lens of Our Evolving Ethics, in Frontiers in Veterinary Science 5:341 (2019)

- WORLD ANIMAL PROTECTION. Animal Protection Index: Swiss Confederation Country Report (2014)

- WORLD ORGANIZATION FOR ANIMAL HEALTH. WAHIS Interface. Switzerland https://www.oie.int/wahis_2/public/wahid.php/Countryinformation/animalsituation [Last consulted 10 July 2019]

- ZECH, M. Une petite intervention empêche de grandes souffrances, in L'Ami des Animaux, 3/15 (24 September 2015)

- ZECH, M. Ces années ont été incroyablement enrichissantes, in L'Ami des Animaux, 1/2019

- 20MIN.CH. Bauern sollen keine Katzen töten dürfen. 12 September 2017 https://www.20min.ch/schweiz/news/story/Bauern-sollen-keine-Katzen-toeten-duerfen-21478946 [Last consulted 28 May 2019] 
- BARCELONA, L'Ordenança sobre la protecció, la tinença i la venda d'animals (2014)

- CHILE, Decreto 1.007, Reglamento que establece la forma y condiciones en que se aplicarán las normas sobre tenencia responsable de mascotas y animales de compañía y determina las normas que permitirán calificar a ciertos especímenes caninos como potencialmente peligrosos (Regulation establishing the form and conditions under which the norms on responsible ownership of pets and companion animals will be applied and determining the standards that will qualify certain canine specimens as potentially dangerous), published 17 August $2018 \mathrm{https}: / /$ www.leychile.cl/Navegar?idNorma=1121980\&idParte=0\&idVersion=

- CHILE, Ley 21.020 sobre tenencia responsable de mascotas y animales de compañía (Law on Responsible Pet Ownership), published 2 August 2017 https://www.leychile.cl/Navegar?idNorma=1106037

- SWITZERLAND, Federal Constitution of the Swiss Confederation (Bundesverfassung der Schweizerischen Eidgenossenschaft, BV), https://www.admin.ch/opc/de/classifiedcompilation/19995395/index.html [unofficial English translation provided for information on Swiss federal government website: https://www.admin.ch/opc/en/classifiedcompilation/19995395/index.html\#a33 ]

- SWITZERLAND, Federal Animal Welfare Act (Tierschutzgesetz, TSchG) (in effect since 1 Sept 2008) https://www.admin.ch/opc/de/classified-compilation/20022103/index.html [unofficial English translation by Interpharma available at: https://www.zuerchertierschutz.ch/fileadmin/user_upload/Tierschutzthemen/pdf/Tierschutzg esetz_e.pdf]

- SWITZERLAND, Federal Animal Welfare Ordinance (Tierschutzverordnung, TSchV) (in effect since 1 Sept 2008) https://www.admin.ch/opc/de/classifiedcompilation/20080796/index.html [unofficial English translation by Interpharma available at: https:/www.blv.admin.ch/dam/blv/en/dokumente/tiere/rechts-undvollzugsgrundlagen/animal-welfare-ordinancetschv.pdf.download.pdf/Animal_Welfare_Ordinance_(TSchV)_position_as_at_1.4.2011.pdf ]

- SWITZERLAND, Civil Code (Schweizerisches Zivilgesetzbuch, ZGB) (in effect since 10 December 1907) https://www.admin.ch/opc/de/classified-compilation/19070042/index.html [unofficial English translation provided for information on Swiss federal government website: https://www.admin.ch/opc/en/classified-compilation/19070042/index.html]

- SWITZERLAND, Criminal Code (Schweizerisches Strafgesetzbuch, StGB) (in effect since 1 January 1942) https://www.admin.ch/opc/de/classified-compilation/19370083/index.html

- SWITZERLAND, Gesetz uber die Jagd und den Schutz wildlebender Säugetiere und Vögel, JSG) (in effect since 1 April 1988) https://www.admin.ch/opc/de/classifiedcompilation/19860156/index.html 